\title{
Unveiling the physiological mechanisms that drive the emergence of antibiotic resisters from antibiotic persister population of mycobacteria
}

Kishor Jakkala, Deepti Sharan, Rashmi Ravindran Nair, Avraneel Paul, Atul Pradhan, Parthasarathi Ajitkumar*

Department of Microbiology and Cell Biology, Indian Institute of Science, Bangalore, Karnataka, India.

${ }^{*}$ Corresponding author; Email: ajitkpartha@gmail.com

Key words: Mycobacteria; Antibiotic persister; Antibiotic resistance; Multi-nucleated cells; Multi-septated cells; Abrupt cell division; Hydroxyl radical 


\section{Abstract}

The physiological mechanisms behind the emergence of antibiotic-resistant bacteria from their antibiotic-persister population are beginning to be explored. Here we delineate the sequential physiological events that drive the emergence of rifampinresistant rpoB mutants from rifampin-persister population of mycobacteria during prolonged exposure. The rifampin-persister population generated elevated levels of hydroxyl radical, which inflicted mutations, enabling regrowth of the persister cells to form multi-septated, multi-nucleated elongated cells. These cells, through multiple divisions, produced multiple sister-daughter cells, causing an abrupt, unexpectedly high increase of rifampin-resistant colonies. Similar response was observed against moxifloxacin also. Earlier studies on the rifampin/moxifloxacin-exposed laboratory/clinical M. tuberculosis strains from in-vitro cultures and infected mouselung also showed cfu spurt, but went unnoticed/unreported. It is likely that these sequential physiological events may be driving the emergence of antibiotic-resistant tubercle bacilli in TB patients also. Escherichia coli also has been found to respond similarly against subminimal inhibitory concentrations of ciprofloxacin. Thus, the present findings attain broad significance as a general physiological mechanism used by diverse bacterial genera to emerge as drug-resistant strains against antibiotics. 


\section{Introduction}

Antibiotic bacterial persisters were first observed in the recurrence of Staphylococcal infections, despite extensive treatments with high doses of penicillin (Hobby et al., 1942; Bigger, 1944). The persisters constitute a subpopulation of cells in a bacterial population that can tolerate lethal concentrations of antibiotics and, upon removal of the antibiotic, can re-grow to generate back the antibiotic sensitive population. The difference between bacterial persistence and antibiotic resistance is that unlike the antibiotic resistant mutants, which grow in the presence of the antibiotic/bactericidal agent, the persister cells do not proliferate in the presence of the antibiotic/bactericidal agent, but resume growth once the antibiotic is removed, giving rise to antibioticsensitive population again (Bigger, 1944). The antibiotic-sensitive population can once again generate persisters in the presence of the antibiotic. Thus, persistence, in contrast to resistance, is a non-inherited phenomenon.

Bacteria, both pathogenic and non-pathogenic, of diverse genera and habitat have shown the phenomenon of persistence. With mycobacteria being no exception to this trait, large number of studies have been carried out on Mycobacterium tuberculosis persisters (Robertson, 1933; McCune et al., 1966a, b; Hu et al., 2000; Lenaerts et al., 2007; Hoff et al., 2011; Sebastian et al., 2017). High density of acidfast bacilli has been found in the tubercles resected months after the patients on chemotherapy had become sputum negative (Medlar et al., 1952; Beck and Yegian, 1952). Similarly, tubercle bacilli have been found in the lung tissues taken at autopsy from individuals who died from reasons unrelated to TB (Opie and Aronson, 1927; Robertson, 1933; reviewed in Stewart et al., 2003). Ovoid shaped, "ultra-fine" forms of infectious bacilli, revivable under certain growth conditions, have been found in the sputum and plasma of TB patients receiving anti-TB therapy (Khomenko, 1987). Mice 
infected with virulent $M$. tuberculosis $\mathrm{H}_{37} \mathrm{R}_{v}$ contained in vitro drug-susceptible persistent bacilli in the lungs and spleen despite treatment with anti-TB drugs (McCune and Tompsett, 1956a; McCune et al., 1956; McCune et al., 1966a; McCune et al., 1966b). The bacterial load in the mouse model was found to remain the same during the persistence of the bacilli indicating non-replicative nature of the persister cells (Rees and D'Arcy Hart, 1961). M. tuberculosis infected guinea pig contained persistent bacilli in the lungs, spleen and in the extracellular milieu, regardless of drug treatment (Lenaerts et al., 2007; Kashino et al., 2008; Hoff et al., 2011). Persistent M. tuberculosis has also been observed in infected macrophages (McKinney et al., 2000; Adams et al., 2011) and in in vitro cultures (Hu et al., 2000; Singh et al., 2010; Keren et al., 2004; Sebastian et al., 2017).

There are many studies that indicate possible association of persistence with drug resistance. Accumulation of point mutations associated with antibiotic resistance developed over several months during treatment has been demonstrated using wholegenome sequencing of Staphylococcus aureus isolates from a patient with persistent infection (Mwangi et al., 2007). Similarly, whole-genome sequencing of $M$. tuberculosis populations in the sputum from patients, who experienced recrudescent infection, revealed hetero-resistance of $M$. tuberculosis population with newly acquired resistance (Sun et al., 2012). Although multiple resistant mutants transiently coexist within the population, only a single type of mutant that is highly adaptive and retained fitness despite the cost towards incurring mutations would get selected and survive (Sun et al., 2012). According to the recent WHO report on TB, $20 \%$ of the retreatment cases harbor MDR-TB, in contrast to $3.3 \%$ of new cases, indicating the possible emergence of resistant mutants in the retreatment cases from uncleared persisters (WHO Global TB Report, 2015). 
It has been proposed that the antibiotic persister cells could behave as an evolutionary reservoir for the emergence of antibiotic-resistant mutants (Cohen et al., 2013; Sebastian et al., 2017). This has been experimentally demonstrated in diverse bacterial systems (reviewed in Cohen et al., 2013), including M. tuberculosis and $M$. smegmatis (Cohen et al., 2013; Sebastian et al., 2017; Swaminath, 2017). The emergence of $M$. smegmatis persisters in vitro upon treatment with rifampin, $\mathrm{INH}$, ciprofloxacin, and ofloxacin has been reported (Grant et al., 2012; Swaminath, 2017). We have recently shown the de novo emergence of rifampin/moxifloxacin-resistant genetic mutants of $M$. tuberculosis and $M$. smegmatis from the respective antibiotic persistence phase cells due to mutagenesis from elevated levels of hydroxyl radical (Sebastian et al., 2017; Swaminath, 2017). The genetically resistant mutants emerged from the persister population of cells despite the continuous presence of microbicidal concentrations of the antibiotic for prolonged duration, such as for 20 days for $M$. tuberculosis and 96 hrs for M. smegmatis cells in vitro (Sebastian et al., 2017; Swaminath, 2017). The antibiotic-resistant genetic mutants regrew and populated the culture in the continued presence of microbicidal concentrations of the antibiotic.

In the background of these studies, we addressed here as to what are the sequential physiologic events that propel the persister cells of mycobacteria against rifampin and moxifloxacin to acquire mutations against antibiotics, regrow, divide, and generate a population of antibiotic-resistant genetic mutants in the continuous presence of the respective antibiotic. Since identical response in terms of sudden spurt in cfu was shown by the antibiotic-resistant genetic mutants of both $M$. smegmatis (saprophyte) and M. tuberculosis (avirulent $\mathrm{H}_{37} \mathrm{R}_{a}$ and virulent $\mathrm{H}_{37} \mathrm{R}_{v}$ ) also, we discussed the relevance of this finding in the emergence of drug-resistant tubercle bacilli in TB patients. 


\section{Results}

Background information and experimental strategy. We had earlier found that $M$. tuberculosis $(M t b)$ and $M$. smegmatis $(M s m)$ cells, which were exposed to minimum bactericidal concentrations (MBCs) of rifampicin and moxifloxacin for prolonged duration in vitro such as 18 days for Mtb cells and 96 hrs for Msm cells, showed a sequential killing, persistence and regrowth phases (Sebastian et al, 2017; Swaminath, 2017). In these studies, rifampicin-resistant and moxifloxacin-resistant genetic mutants of Mtb and Msm were found to emerge from the persister population, regrow and populate the culture. The rifampicin-resistant and moxifloxacin-resistant mutants were having nucleotide changes at the rifampicin resistance determining region (RRDR) and quinolone resistance determining region (QRDR), respectively (Sebastian et al, 2017; Swaminath, 2017). These mutations were identical to and at identical positions as those observed in the rifampicin-resistant and moxifloxacinresistant clinical isolates of $M t b$ (Cavusoglu et al., 2002; Takiff et al., 1994). Since this phenomenon was found in both Mtb and Msm cells and irrespective of the antibiotic used, the present study was performed using Msm cells only for faster pace of getting colonies and response from the cells against antibiotics. However, to present the response of Mtb cells to rifampicin and moxifloxacin, we have considered the cfu values corresponding to the graphs depicting the Mtb susceptibility to rifampicin and moxifloxacin, respectively, from the earlier published work from our laboratory (Sebastian et al, 2017; Copyright @ American Society for Microbiology, Antimicrobial Agents and Chemotherapy, 61, 2017, e01343-16, https://doi.org/10.1128/AAC.0134316). In this work, the unexpectedly high levels of cfu spurts that occurred against rifampicin and moxifloxacin were not reported as they went unnoticed by us. 
Thus, as per the rationale mentioned above, we exposed Msm mid-log phase (MLP) cells individually to MBCs of rifampin or moxifloxacin and plated on the antibiotic-free and/or antibiotic-containing (125 $\mu \mathrm{g} / \mathrm{ml}$ rifampin; 3x MBC, Sharmada, 2017) Mycobacteria 7H11 agar plates once every 6 hrs for 120 hrs for the determination of total cfu and the cfu of antibiotic-resistant mutants, respectively. Depending upon the conspicuous changes in the cfu on the antibiotic-free plates during the entire exposure period, the killing phase with exponential reduction in the cfu, the persistence phase with no appreciable change in the cfu, and the regrowth phase showing steady rise in the cfu, were temporally demarcated. The different phases were identified to isolate the cells from the respective phase for the analyses.

The colonies from the rifampin-free plates were patch-plated onto rifampincontaining plates to identify which of the colonies that grew on rifampin-free plates were actually rifampin-resistant. These colonies from both the antibiotic-free and antibiotic-containing plates were selected from five time points for RRDR sequence determination. These time points included the time point showing abrupt several-fold high spurt in cfu, two time points prior to and two time points later to the time point of sudden spurt in cfu. The cells from these time points were examined using transmission electron microscopy, atomic force microscopy, fluorescence microscopy, and live-cell imaging for cell division, filamentation, if any, and for the presence of multiple nucleoids and multiple septae. The number of cells with $\leq 2 n$ and $>2 n$ nucleoids were quantitated for the cells from these five time points. The initial cell density chosen for the experiment was $10^{6} \mathrm{cells} / \mathrm{ml}$ to pre-empt the natural resisters to rifampicin that exist at $10^{-8}$ frequency in the MLP culture (Swaminath, 2017). All the experiments were performed using biological triplicate samples and statistical significance of the observations was calculated. Similar analyses were performed for 
the Msm cells exposed to $3.75 x$ MBC moxifloxacin for prolonged duration, as reported (Swaminath, 2017). However, the mutations in the gyrA gene in the moxifloxacinresistant mutants formed from the persisters were not determined since the response of the bacilli to moxifloxacin was identical to that to rifampin. Further, the mutations in the moxifloxacin-resistant genetic mutants formed from the persisters were already determined in the recent study on Msm persisters against moxifloxacin from our laboratory (Swaminath, 2017).

The response of Msm cells to MBCs of rifampin and moxifloxacin. The rifampin susceptibility curve obtained from the cfu on the rifampin-free plate showed a killing phase, with a steady decline in the cfu $\left(\sim 3-\log _{10}\right.$ reduction in the $\left.\mathrm{cfu}\right)$, from $0 \mathrm{hr}$ to 36 hr (Fig. 1A). The killing phase was followed by the persistence phase, from $36 \mathrm{hr}$ to $54 \mathrm{hr}$, characterised by practically no appreciable change in the cfu (Fig. 1A). The persistence phase was ensued by the regrowth phase, from 54 to $120 \mathrm{hr}$, where a steady rise in the cfu by $\sim 4-\log _{10}$ difference could be observed (Fig. 1A). The temporal demarcation of the three phases in terms of the change/no change in the cfu enabled isolation of the cells from the persistence and regrowth phases for further analyses. A response, similar to that shown to rifampin, was found from the Msm cells to MBC of moxifloxacin $\left(0.5 \mathrm{\mu g} \mathrm{ml}^{-1} ; 3.75 \times \mathrm{MBC}\right)$ upon prolonged exposure for $96 \mathrm{hrs}$ (Fig. 1B), as reported in our recent study (Swaminath, 2017). Here also, in terms of the changes in the cfu from the moxifloxacin-free plates, the killing (from $0 \mathrm{hr}$ to $36 \mathrm{hr}$ ), persistence (from $36 \mathrm{hr}$ to $54 \mathrm{hr}$ ), and regrowth (from $54 \mathrm{hr}$ to $96 \mathrm{hr}$ ) phases could be identified. Thus, despite the modes and targets of action of rifampin and moxifloxacin being different, Msm cells showed identical response to them, with the emergence of regrowing population in the continued presence of MBCs of the respective antibiotics. 
A

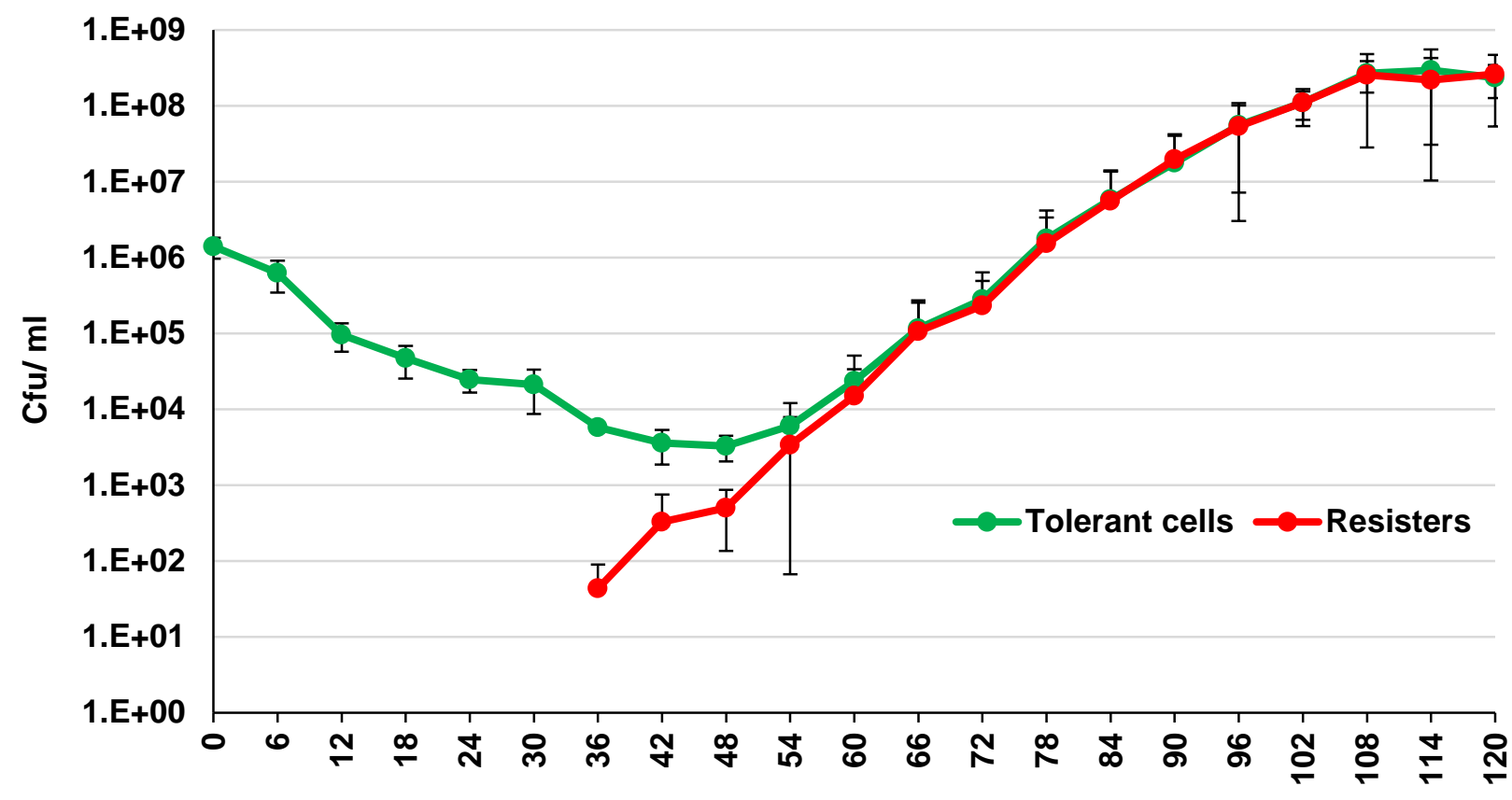

Time (hrs)

B

Msm MOX

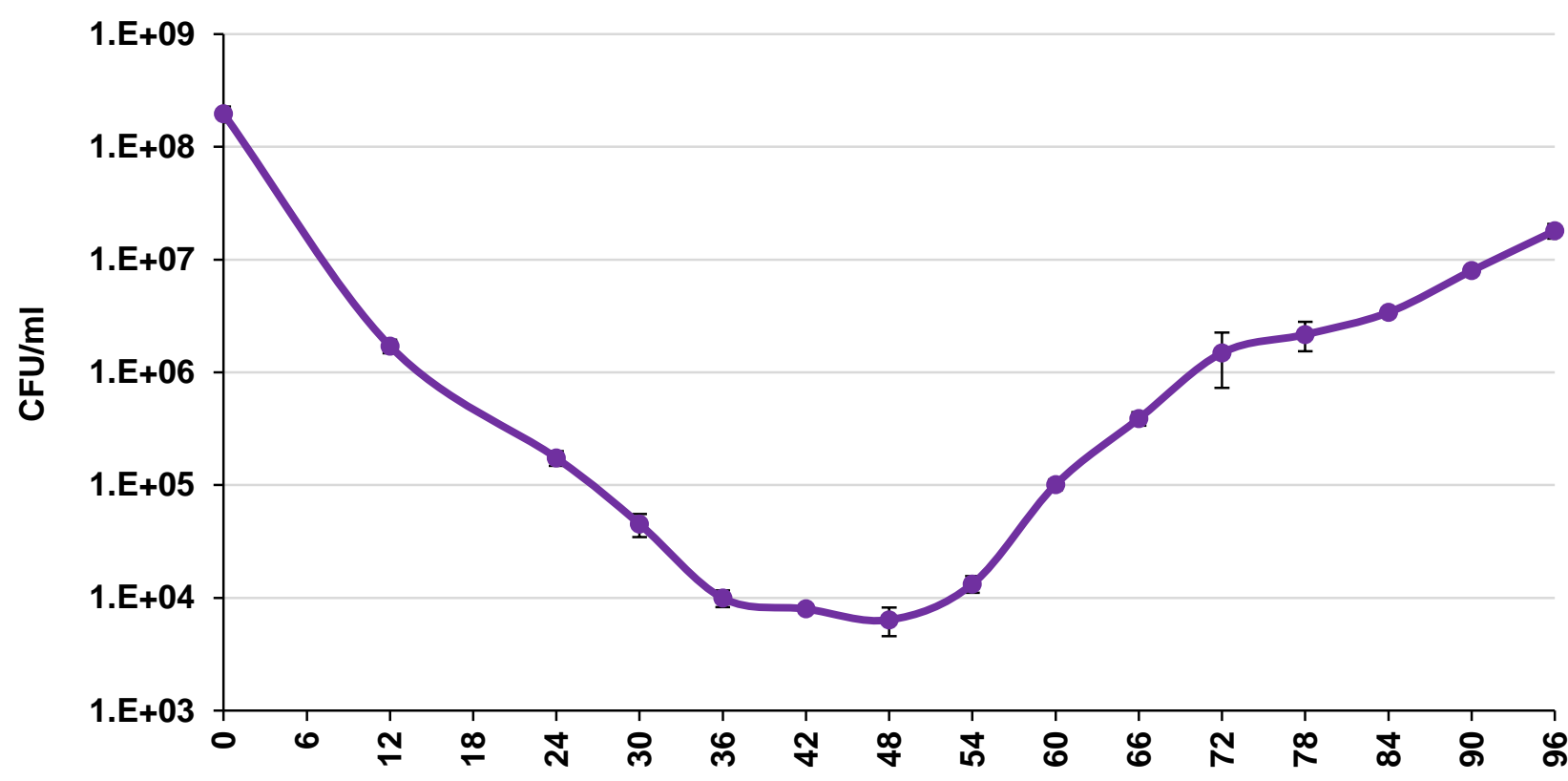

Time (hrs)

Figure 1. Response of Mycobacterium smegmatis cells to rifampin and moxifloxacin upon prolonged exposure. Response to: (A) rifampin $\left(25 \mu \mathrm{g} \mathrm{ml}^{-1}\right)$ and (B) moxifloxacin $(0.5$ $\left.\mu \mathrm{g} \mathrm{ml}^{-1}\right)$. The profiles show clear killing phase $(0 \mathrm{hr}$ to $36 \mathrm{hr}$ with steep decrease in the $\mathrm{cfu}$ ), followed by the persistence phase ( $36 \mathrm{hr}$ to $54 \mathrm{hr}$ with no appreciable change in the cfu), and continued by the regrowth phase (from $54 \mathrm{hr}$ till 96/120 hr with steady rise in cfu). The red line in (A) indicate the cfu of rifampin-resisters that emerged from the persister population. The moxifloxacin-resisters were not scored (see text for explanation). 
The response of Mtb cells to MBCs of rifampin and moxifloxacin. Earlier, we had shown the response of Mtb cells upon prolonged exposure (20 days) to microbicidal concentrations of rifampin (10x MBC) and moxifloxacin (2x MBC) (Fig. S1A,B here, which are Fig. $1 \mathrm{~A}$ and Fig. S2 in Sebastian et al, 2017, taken with copyright permission from AAC). The susceptibility profile of Mtb cells to MBCs of rifampicin and moxifloxacin also showed killing, persistence and regrowth phases, wherein the regrowing cells were found to emerge from the persister population, like in the case of Msm cells exposed to the two antibiotics. Further, our recent studies on Mtb and Msm cells exposed to rifampicin and moxifloxacin for prolonged duration showed that the cells regrowing from the respective persister population in the continued presence of MBCs of the antibiotics were antibiotic-resistant genetic mutants carrying mutations in the rpoB and gyrA targets (Sebastian et al, 2017; Swaminath, 2017).

This dynamic change in the respective antibiotic persister population from a nongrowing, non-dividing, but antibiotic-tolerant state to an actively growing and dividing antibiotic-resistant state offered an excellent experimental system to identify and characterise the physiological events that accompanied such dynamic change that led to the emergence of antibiotic-resistant mutants. Further, the comparable response of Msm and Mtb cells to the same antibiotics indicated that the nature of the response of mycobacteria upon prolonged exposure to microbicidal concentrations of antibiotics is an inherent trait that is not influenced by the species type, saprophytic or pathogenic character of the bacterium or by the nature of the antibiotics or the differences in the targets or the cellular processes affected by them. Moreover, such similarity also indicated commonality in the mechanisms involved, justifying the use of Msm as the model system to study the physiological events that drive the emergence of antibioticresistant mutants from the persister population. 
A
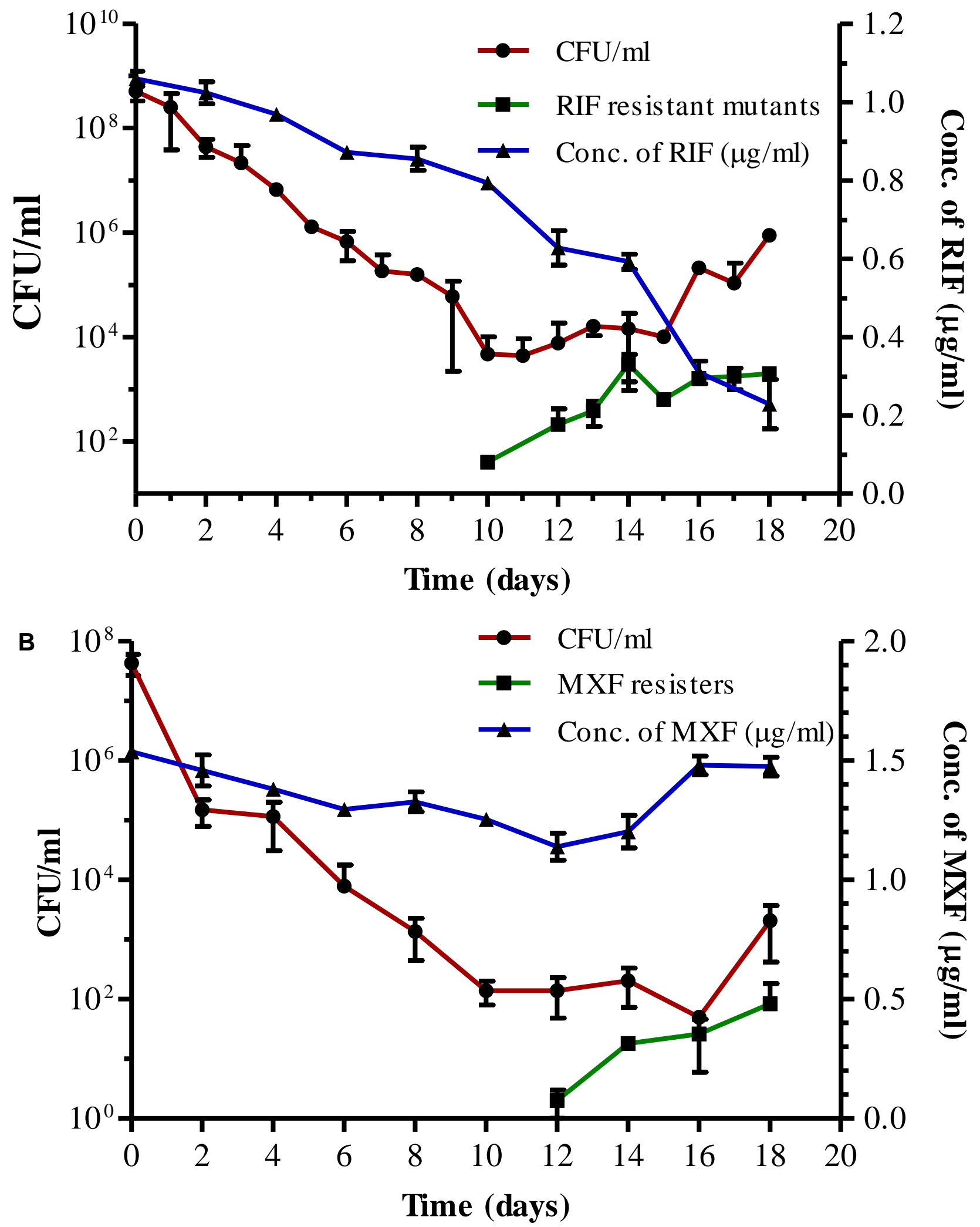

Fig. S1. Susceptibility profile of Mtb cells to MBCs of rifampicin and moxifloxacin. (A) The susceptibility profile of $M t b$ cells, exposed to $10 x \mathrm{MBC}$ rifampicin $(1 \mu \mathrm{g} / \mathrm{ml})$ for 18 days, obtained by plating aliquotes of the culture on rifampicin-free plate every day ( $\bullet$; red line) and in parallel on rifampicin-containing $(50 x \mathrm{MBC})$ plates $(\mathbf{-}$; green line). The right $y$-axis shows the concentration of rifampicin during the exposure for 18 days ( $\mathbf{\Lambda}$; blue line). (B) The susceptibility profile of $M$ tb cells, during exposure to $2 x \mathrm{MBC}$ moxifloxacin $(1 \mu \mathrm{g} / \mathrm{ml})$ for 18 days, obtained by plating aliquotes of the culture on moxifloxacin-free plate every day $(\bullet$; red line) and in parallel on moxifloxacin-containing $(4 x$ $\mathrm{MBC}$ ) plates ( $\mathbf{-}$; green line). Right $\mathrm{Y}$-axis shows the moxifloxacin concentration during the entire exposure period. Sebastian et al, 2017; Copyright @ American Society for Microbiology, Antimicrobial Agents and Chemotherapy, 61, 2017, e01343-16, https://doi.org/10.1128/AAC.01343-16. 
Abrupt abnormally high spurt in the cfu of antibiotic-tolerant Msm cells regrowing from the persister population. The cfu of the persister phase cells $(36 \mathrm{hr}$ to $54 \mathrm{hr}$ ) on the rifampin-free plates did not show any notable increase (Fig. $\mathbf{2 A}, \mathbf{n}=$ 3; Table 1A, rifampin replicates). The cfu started increasing from $60 \mathrm{hr}$, with the value abruptly spurting 2-3-fold above the expected cell number doubling consistently during 90-96 hr period (Fig. 2A, $\mathbf{n}=3$; Table 1A, rifampin replicates). Since the cell number doubling time of Msm cells in nutrient broth is $~ 3 \mathrm{hrs}$ (Gadagkar \& Gopinathan, 1980), a 2-fold increase in the cfu was expected in $3 \mathrm{hrs}$ and 4-fold in $6 \mathrm{hrs}$. But unexpected, unusually high, 2-3 times higher than the 4-fold (i.e., 8-10-fold higher), increase in the cfu was observed in 6 hrs in the rifampin-tolerant cells (Fig. 2A, Table $1 A ; n=3)$.

Although we have observed the unusually high abrupt spurt in the cfu consistently several times $(n>3)$ during the $90-96 \mathrm{hr}$ period, the abrupt unexpectedly high spurt in the cfu occurred at other periods $(72-78 \mathrm{hr}, 78-84 \mathrm{hr}, 84-90 \mathrm{hr}, 96-102$ $\mathrm{hr}$, and 108-114 hr) as well, among the replicates (Fig. 2A, $\mathbf{n}=3$; Table 1A, rifampin replicates). Hence an averaging of the cfu values for the time points amongst the biological replicates was not attempted. Nevertheless, it was of interest to note that the spurt in the cfu always occurred during the regrowth phase of the persister population, albeit during different periods, but more often during the $90-96 \mathrm{hr}$ period. Essentially, these could be the rifampin-tolerant cells that were regrowing from the persister population, probably after gaining antibiotic-target specific mutation. Since the spurts in the cfu were found at different periods during the regrowth phase, the cfu were formed through fresh rounds of growth and division and not just a carryover of the same number of mutants from one period to the other. 
(A) Msm rifampin-tolerant cells
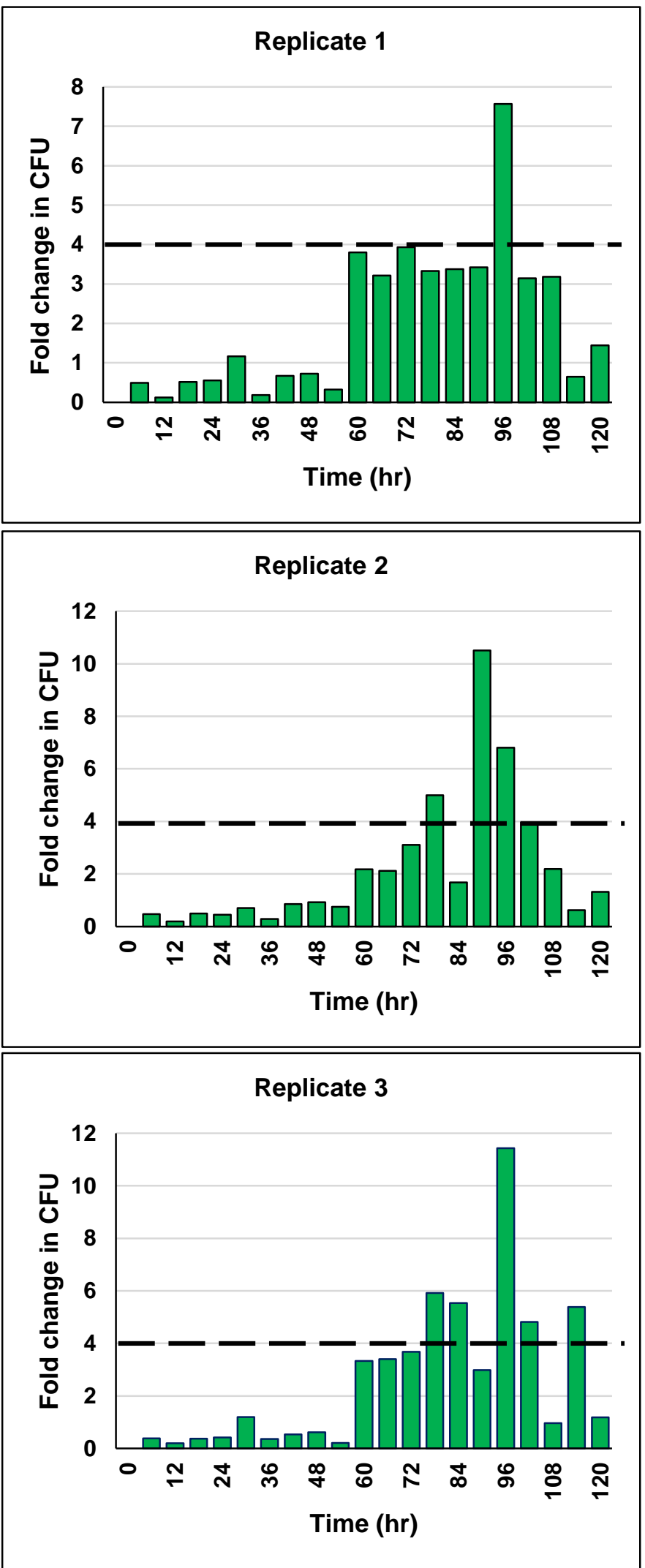

(B) Msm moxifloxacin-tolerant cells
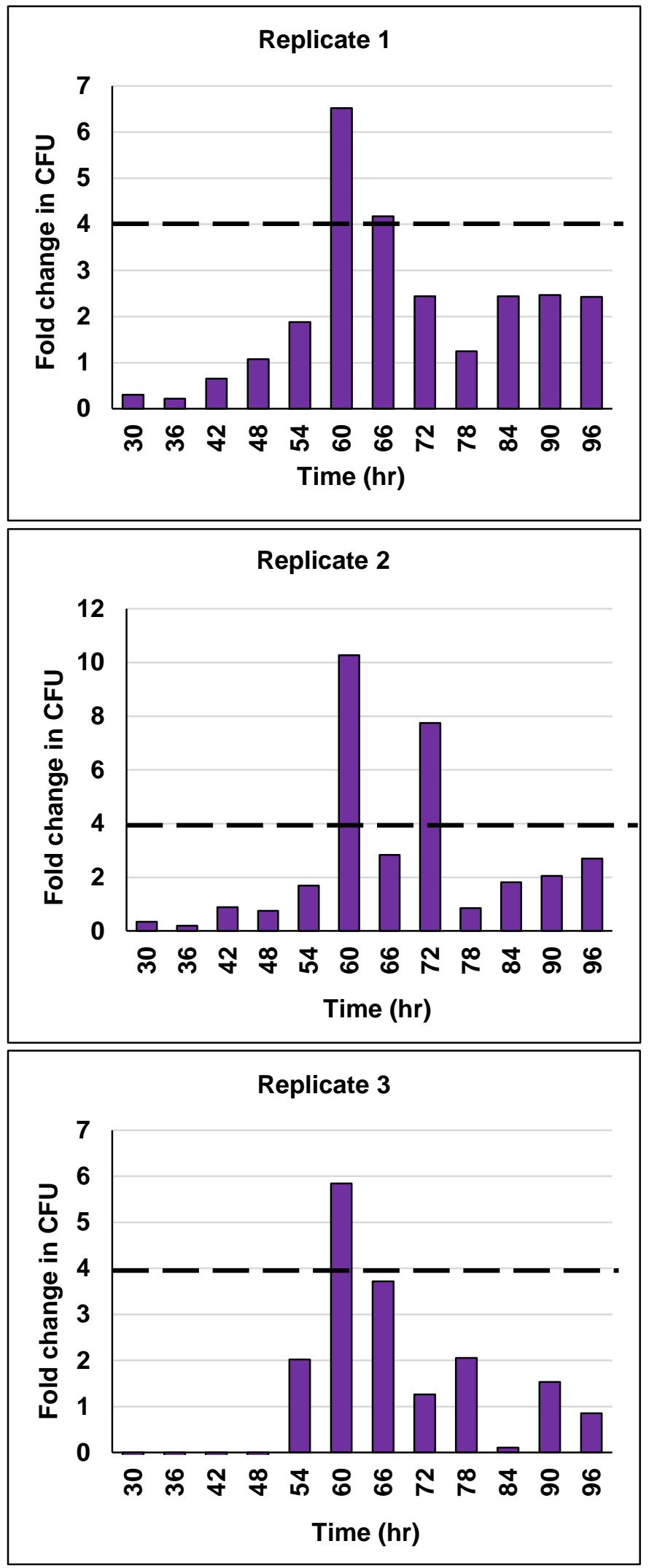

Figure 2. Response of $M$. smegmatis upon prolonged exposure to rifampin and moxifloxacin. Rifampin and moxifloxacin were used at $25 \mu \mathrm{g} \mathrm{ml}^{-1}$ and $0.5 \mu \mathrm{g} \mathrm{ml}^{-1}$, respectively, for exposure. The cfu, from rifampin-free and moxifloxacin-free Mycobacteria $7 \mathrm{H} 11$ agar plates, every $6 \mathrm{hrs}$ during the exposure, was determined. The fold-increase in the cfu, with respect to the cfu of the previous time point, was plotted for: (A) rifampin-exposed and (B) moxifloxacin-exposed cells. The dotted line indicates the maximum expected increase in the cfu in $6 \mathrm{hr}$ period (i.e., 4-fold, as the generation time of Msm cells is $3 \mathrm{hrs}$ ). $\mathrm{n}$ $=3$ biological replicates in both cases. 
Table 1. The observed and the expected CFU values of rifampin-tolerant and moxifloxacin-tolerant Msm cells regrowing from the respective persister population.

(A)

(B)

Rifampin replicate 1

\author{
Rifampin \\ replicate 2
}

Rifampin replicate 3

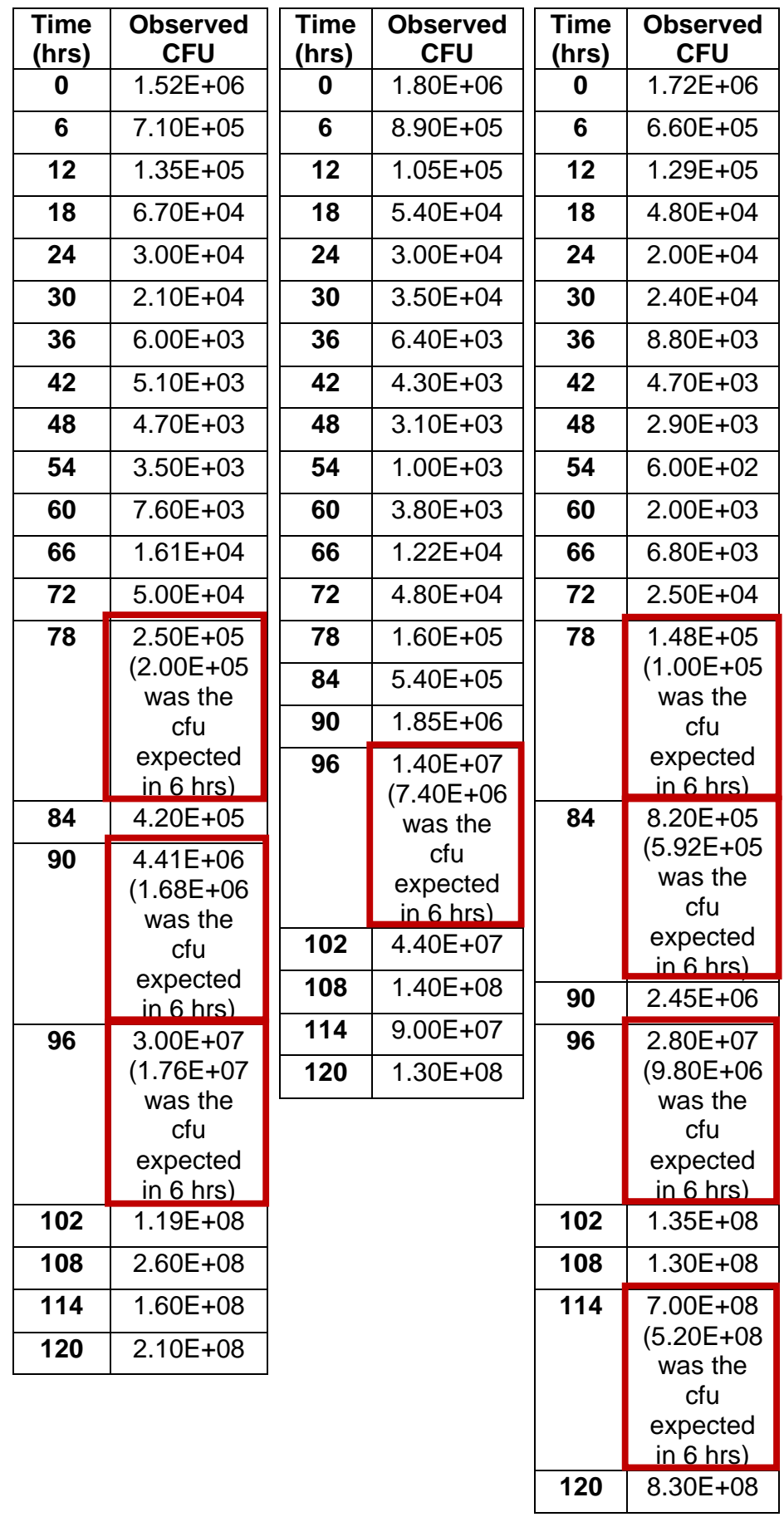

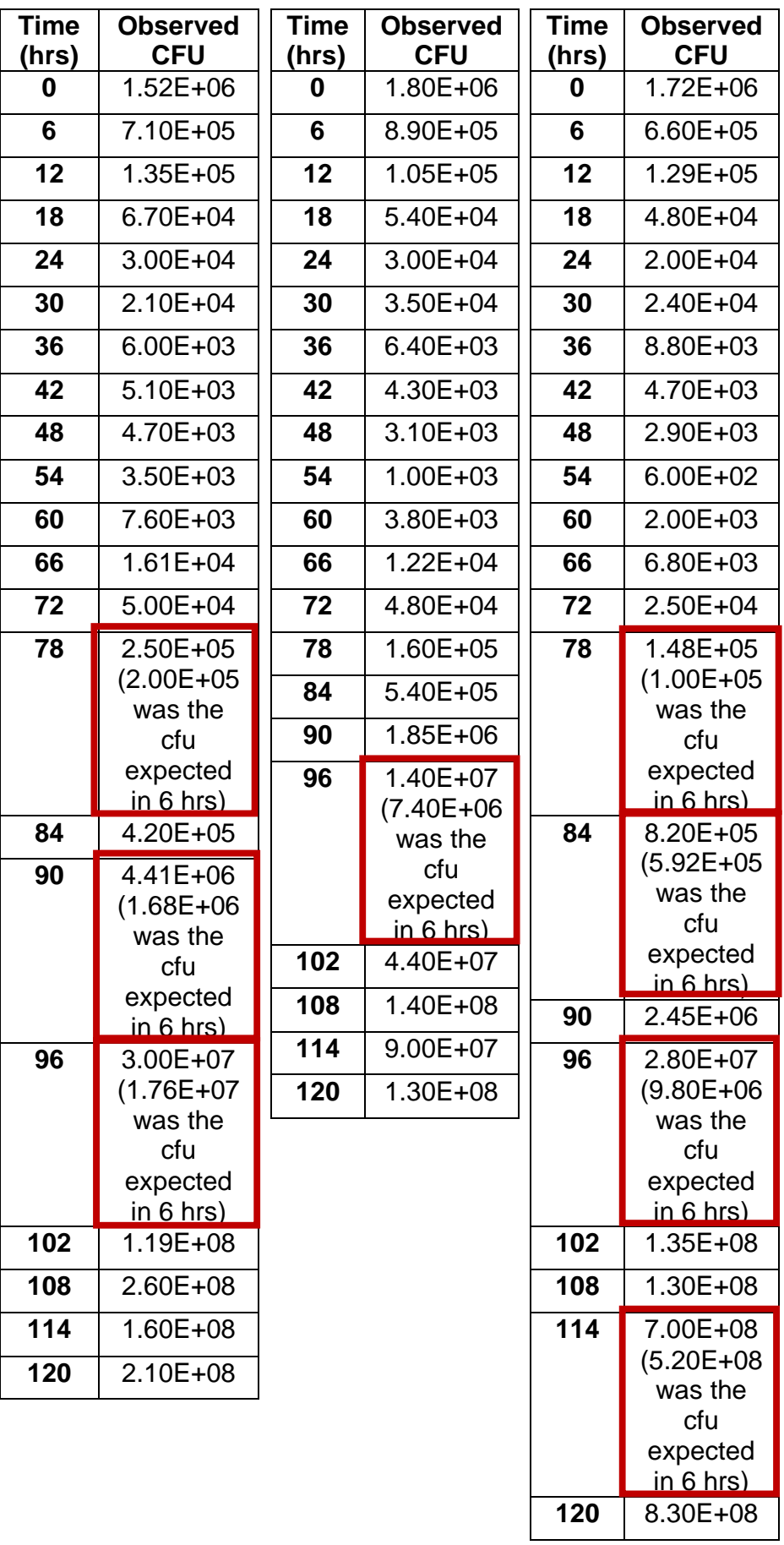

\section{Moxifloxacin replicate 1}

\begin{tabular}{|c|c|}
\hline $\begin{array}{l}\text { Time } \\
\text { (hrs) }\end{array}$ & $\begin{array}{l}\text { Observed } \\
\text { CFU }\end{array}$ \\
\hline 30 & $5.43 \mathrm{E}+04$ \\
\hline 36 & $1.19 \mathrm{E}+04$ \\
\hline 42 & $7.80 \mathrm{E}+03$ \\
\hline 48 & $8.40 \mathrm{E}+03$ \\
\hline 54 & $1.60 \mathrm{E}+04$ \\
\hline 60 & $\begin{array}{c}1.02 \mathrm{E}+05 \\
(6.40 \mathrm{E}+04 \\
\text { was the } \\
\text { cfu } \\
\text { expected } \\
\text { in } 6 \mathrm{hrs})\end{array}$ \\
\hline 66 & 4.30E+05 \\
\hline 72 & $1.05 E+06$ \\
\hline 78 & $1.50 \mathrm{E}+06$ \\
\hline 84 & $3.20 \mathrm{E}+06$ \\
\hline 90 & $8.00 \mathrm{E}+06$ \\
\hline 96 & $1.80 \mathrm{E}+07$ \\
\hline
\end{tabular}

\section{Moxifloxacin replicate 3}

\begin{tabular}{|c|c|c|c|}
\hline $\begin{array}{c}\text { Time } \\
\text { (hr) }\end{array}$ & $\begin{array}{c}\text { Observed } \\
\text { CFU }\end{array}$ & $\begin{array}{c}\text { Time } \\
(\mathrm{hr})\end{array}$ & $\begin{array}{c}\text { Observed } \\
\text { CFU }\end{array}$ \\
\hline 30 & $4.89 \mathrm{E}+04$ & 30 & $3.21 \mathrm{E}+04$ \\
\hline 36 & $9.80 \mathrm{E}+03$ & 36 & $8.20 \mathrm{E}+03$ \\
\hline 42 & $8.70 \mathrm{E}+03$ & 42 & $7.50 \mathrm{E}+03$ \\
\hline 48 & $6.50 \mathrm{E}+03$ & 48 & $4.30 \mathrm{E}+03$ \\
\hline 54 & $1.10 \mathrm{E}+04$ & 54 & $1.30 \mathrm{E}+04$ \\
\hline 60 & $\begin{array}{c}1.13 \mathrm{E}+05 \\
(4.40 \mathrm{E}+04 \\
\text { was the } \\
\text { cfu } \\
\text { expected } \\
\text { in } 6 \mathrm{hrs})\end{array}$ & 60 & $\begin{array}{c}8.90 \mathrm{E}+04 \\
(5.20 \mathrm{E}+04 \\
\text { was the } \\
\text { cfu } \\
\text { expected } \\
\text { in } 6 \mathrm{hrs})\end{array}$ \\
\hline 66 & $3.20 \mathrm{E}+05$ & 66 & $4.20 \mathrm{E}+05$ \\
\hline \multirow[t]{4}{*}{72} & \multirow{4}{*}{$\begin{array}{c}2.48 \mathrm{E}+06 \\
(1.28 \mathrm{E}+06 \\
\text { was the } \\
\text { cfu } \\
\text { expected } \\
\text { in } 6 \mathrm{hrs})\end{array}$} & 72 & $9.50 \mathrm{E}+05$ \\
\hline & & 78 & $2.90 \mathrm{E}+06$ \\
\hline & & 84 & $3.20 \mathrm{E}+06$ \\
\hline & & 90 & $8.10 \mathrm{E}+06$ \\
\hline 78 & $2.10 \mathrm{E}+06$ & 96 & $1.50 \mathrm{E}+07$ \\
\hline 84 & $3.80 \mathrm{E}+06$ & & \\
\hline 90 & $7.80 \mathrm{E}+06$ & & \\
\hline 96 & $2.10 \mathrm{E}+07$ & & \\
\hline
\end{tabular}

Table 1. CFU values of $M$. smegmatis cells exposed to MBCs of rifampin and moxifloxacin. Tables showing the observed and the expected CFU values (in parenthesis) of 3 biological replicates of Msm cells exposed to MBCs of rifampin and moxifloxacin at every 6-hr time interval on the respective antibiotic-free Mycobacteria $7 \mathrm{H} 11$ agar plates for three biological replicates. Considering that the maximum expected fold-increase in the CFU of Msm cells will be 4-fold in 6 hrs (generation being $3 \mathrm{hrs}$ ), the time points showing an abrupt increase in the CFU, which is more than the expected value (from two doublings in cell number) are highlighted in red coloured boxes. Except for the 90-96 hrs period for the rifampin-exposed cells and for the 54-60 hrs period for the moxifloxacin-exposed cells, the time points for the spurt in CFU varied among the replicates. The 0-24 hr period for moxifloxacin-exposed samples are not shown as there was no increase in cfu (see Fig. $2 \mathrm{~B}$ ). 
Identical response was shown by the Msm cells exposed for prolonged duration to moxifloxacin also. In the moxifloxacin-exposed cells, the cfu spurt to abnormal levels (8-10-fold higher than expected) occurred more often during the 54-60 hr period, although such spurts in the cfu occurred during the 66-72 $\mathrm{hr}$ period as well, among the three biological replicates (Fig. 2B, $\mathbf{n}=3$; Table 1B, moxifloxacin replicates). Like in the case of rifampin-exposed cells, these cells might be the moxifloxacin-tolerant cells that were regrowing from the persister population, probably after gaining moxifloxacin-target specific mutation.

\section{Abrupt unusually high spurt in the cfu of rifampin-resistant Msm cells regrowing}

from the persister population. In parallel to plating on rifampin-free plates mentioned above, we had plated an aliquot each of the samples from the same time points on rifampin-containing plates also. Like in the case of rifampin-tolerant cells, the cfu on the rifampin-containing plates also showed a sudden 2-fold to 3-fold higher value (i.e., 8-10-fold higher) than the 4-fold increase in the cfu that was expected in the resisters at different time points, amongst the biological triplicate samples (Fig. $\mathbf{3 A}, \mathbf{B} ; \mathbf{n}=\mathbf{3}$ ). The sudden unexpectedly high spurt in the cfu was observed most often during the 54-60 hr period, although such spurts in the cfu were found during other periods (42$48 \mathrm{hr}, 48-54 \mathrm{hr}, 60-66 \mathrm{hr}, 66-72 \mathrm{hr}, 72-78 \mathrm{hr}, 78-84 \mathrm{hr}, 84-90 \mathrm{hr}, 90-96 \mathrm{hr}, 96-102 \mathrm{hr}$, and 108-114 hr) as well (Fig. 3B; $\mathbf{n}=3$ ). Again, since the cfu spurts occurred at different periods during the regrowth phase, the cfu were contributed by the cells formed through fresh rounds of growth and division. Thus, they were not constituted by a carryover of the same number of mutants from one period to the other. This indicated active growth and division of rifampin-resistant mutants in the continued presence of microbicidal concentrations of the antibiotic. 

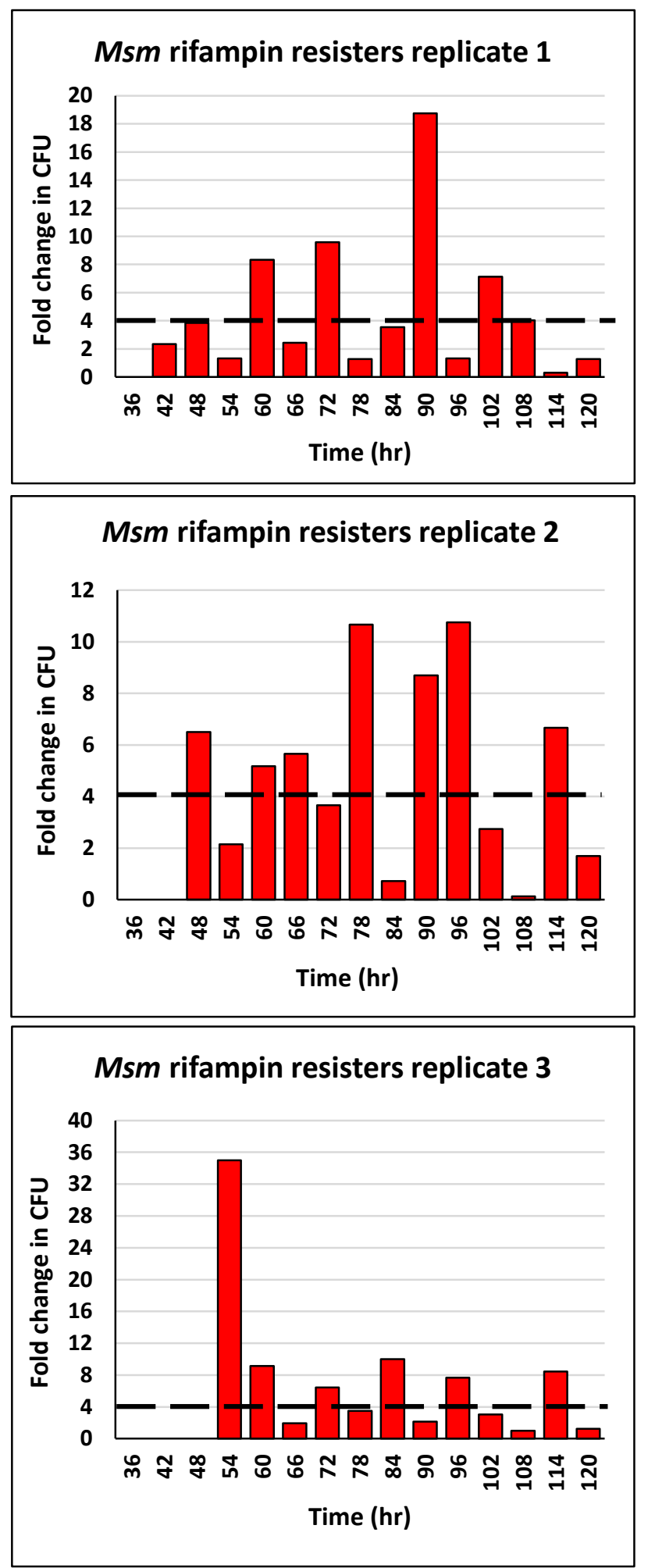

Figure 3. Unusually high level of emergence of rifampin resisters from the cells regrowing from $M$. smegmatis persister population during prolonged exposure to rifampin. CFU and fold-change in CFU of the Msm cells exposed to rifampin $(25 \mu \mathrm{g}$ $\left.\mathrm{ml}^{-1}\right)$ and plated on rifampin-containing (125 $\left.\mu \mathrm{g} \mathrm{ml} \mathrm{m}^{-1}\right)$ Mycobacteria 7H11 agar every $6 \mathrm{hrs}$ during the exposure. (A) The fold-change in CFU compared to the CFU of the previous time point of the biological triplicates. Maximum expected increase in the CFU within $6 \mathrm{hrs}$ (4-fold) is indicated by the dotted line. (B) The actual CFU values of the biological triplicates.

\section{Replicate 2}

\begin{tabular}{|c|c|}
\hline $\begin{array}{c}\text { Time } \\
\text { (hrs) }\end{array}$ & $\begin{array}{c}\text { Observed } \\
\text { CFU }\end{array}$ \\
\hline $\mathbf{3 6}$ & $3.00 \mathrm{E}+01$ \\
\hline $\mathbf{4 2}$ & $7.00 \mathrm{E}+01$ \\
\hline $\mathbf{4 8}$ & $2.70 \mathrm{E}+02$ \\
\hline $\mathbf{5 4}$ & $3.60 \mathrm{E}+02$ \\
\hline $\mathbf{6 0}$ & $\begin{array}{c}3.00 \mathrm{E}+03 \\
(1.44 \mathrm{E}+0 \\
3 \text { was the } \\
\text { cfu } \\
\text { expected } \\
\text { in } 6 \text { hrs })\end{array}$ \\
\hline $\mathbf{6 6}$ & $7.30 \mathrm{E}+03$ \\
\hline $\mathbf{7 2}$ & $\begin{array}{c}7.00 \mathrm{E}+04 \\
(2.92 \mathrm{E}+0 \\
4 \text { was the } \\
\text { cfu } \\
\text { expected } \\
\text { in } 6 \text { hrs })\end{array}$ \\
\hline $\mathbf{7 8}$ & $9.00 \mathrm{E}+04$ \\
\hline $\mathbf{8 4}$ & $3.20 \mathrm{E}+05$ \\
\hline $\mathbf{9 0}$ & $\begin{array}{c}6.00 \mathrm{E}+06 \\
(1.28 \mathrm{E}+0 \\
6 \text { was the } \\
\text { cfu } \\
\text { expected } \\
\text { in } 6 \text { hrs })\end{array}$ \\
\hline $\mathbf{8 6}$ & $\begin{array}{c}8.00 \mathrm{E}+06 \\
\text { (3.70E+07 } \\
(3.20 \mathrm{E}+0 \\
7 \text { was the } \\
\text { cfu } \\
\text { expected } \\
\text { in } 6 \text { hrs })\end{array}$ \\
\hline $\mathbf{1 0 8}$ & $2.30 \mathrm{E}+08$ \\
\hline $\mathbf{1 1 4}$ & $7.00 \mathrm{E}+07$ \\
\hline $\mathbf{1 2 0}$ & $9.00 \mathrm{E}+07$ \\
\hline
\end{tabular}

Replicate 3

\begin{tabular}{|c|c|c|c|}
\hline $\begin{array}{l}\text { Time } \\
\text { (hrs) }\end{array}$ & $\begin{array}{l}\text { Observed } \\
\text { CFU }\end{array}$ & $\begin{array}{l}\text { Time } \\
\text { (hrs) }\end{array}$ & $\begin{array}{c}\text { Observed } \\
\text { CFU }\end{array}$ \\
\hline 42 & $4.00 \mathrm{E}+01$ & 48 & $1.00 \mathrm{E}+01$ \\
\hline 48 & $\begin{array}{c}2.60 \mathrm{E}+02 \\
(1.60 \mathrm{E}+02 \\
\text { was the } \\
\text { cfu } \\
\text { expected } \\
\text { in } 6 \mathrm{hrs})\end{array}$ & 54 & $\begin{array}{c}3.50 \mathrm{E}+02 \\
(4.00 \mathrm{E}+01 \\
\text { was the } \\
\text { cfu } \\
\text { expected } \\
\text { in } 6 \mathrm{hrs})\end{array}$ \\
\hline 54 & $5.60 \mathrm{E}+02$ & \multirow[t]{2}{*}{60} & $\begin{array}{c}3.20 E+03 \\
(1.40 E+03\end{array}$ \\
\hline \multirow[t]{3}{*}{60} & \multirow{3}{*}{$\begin{array}{c}2.90 \mathrm{E}+03 \\
(2.24 \mathrm{E}+03 \\
\text { was the } \\
\text { cfu } \\
\text { expected } \\
\text { in } 6 \mathrm{hrs})\end{array}$} & & $\begin{array}{l}\text { was the } \\
\text { cfu } \\
\text { expected } \\
\text { in } 6 \mathrm{hrs} \text { ) }\end{array}$ \\
\hline & & 66 & $6.20 \mathrm{E}+03$ \\
\hline & & \multirow[t]{2}{*}{72} & \multirow[b]{2}{*}{$\begin{array}{c}4.00 \mathrm{E}+04 \\
(2.48 \mathrm{E}+04 \\
\text { was the } \\
\text { cfu } \\
\text { expected } \\
\text { in } 6 \mathrm{hrs})\end{array}$} \\
\hline \multirow[t]{3}{*}{66} & \multirow{3}{*}{$\begin{array}{c}1.64 \mathrm{E}+04 \\
(1.16 \mathrm{E}+04 \\
\text { was the } \\
\text { cfu } \\
\text { expected } \\
\text { in } 6 \mathrm{hrs})\end{array}$} & & \\
\hline & & 78 & $1.40 \mathrm{E}+05$ \\
\hline & & \multirow[t]{3}{*}{84} & $1.40 \mathrm{E}+06$ \\
\hline 72 & $6.00 \mathrm{E}+04$ & & $(5.60 \mathrm{E}+05$ \\
\hline \multirow[t]{3}{*}{78} & \multirow{3}{*}{$\begin{array}{c}6.40 \mathrm{E}+05 \\
(2.40 \mathrm{E}+05 \\
\text { was the } \\
\text { cfu } \\
\text { expected } \\
\text { in } 6 \mathrm{hrs})\end{array}$} & & $\begin{array}{l}\text { was the } \\
\text { cfu } \\
\text { expected } \\
\text { in } 6 \mathrm{hrs} \text { ) }\end{array}$ \\
\hline & & 90 & $3.00 \mathrm{E}+06$ \\
\hline & & \multirow[t]{3}{*}{96} & $2.30 \mathrm{E}+07$ \\
\hline 84 & $4.60 \mathrm{E}+05$ & & $(1.20 \mathrm{E}+07$ \\
\hline \multirow[t]{3}{*}{90} & \multirow{3}{*}{$\begin{array}{c}4.00 \mathrm{E}+06 \\
(1.84 \mathrm{E}+06 \\
\text { was the } \\
\text { cfu } \\
\text { expected } \\
\text { in } 6 \mathrm{hrs})\end{array}$} & & $\begin{array}{l}\text { was the } \\
\text { cfu } \\
\text { expected } \\
\text { in } 6 \mathrm{hrs} \text { ) }\end{array}$ \\
\hline & & 102 & $7.00 \mathrm{E}+07$ \\
\hline & & 108 & $7.00 \mathrm{E}+07$ \\
\hline 96 & $\begin{array}{c}\text { In } 6 \mathrm{hrs}) \\
4.30 \mathrm{E}+07 \\
(1.60 \mathrm{E}+07 \\
\text { was the } \\
\text { cfu } \\
\text { expected }\end{array}$ & 114 & $\begin{array}{c}5.90 \mathrm{E}+08 \\
(2.80 \mathrm{E}+08 \\
\text { was the } \\
\text { cfu } \\
\text { expected } \\
\text { in } 6 \mathrm{hrs})\end{array}$ \\
\hline 102 & $\frac{\text { in } 6 \mathrm{hrs})}{1.18 \mathrm{E}+08}$ & 120 & $7.40 \mathrm{E}+08$ \\
\hline
\end{tabular}




\section{Sudden abnormally high spurt in the cfu of antibiotic-tolerant/resistant Mtb cells} regrowing from the persister population. We had earlier shown the de novo emergence of rifampicin-resistant and moxifloxacin-resistant Mtb cells regrowing from the respective persister population of Mtb cells formed upon exposure to the respective antibiotic for prolonger duration (Sebastian et al., 2017). The persistence phase of the Mtb cells exposed to rifampicin and moxifloxacin was found to be from day 10 to day 15 and day 16 , respectively, subsequent to which regrowth started (Fig. 1A and Fig. S2 in Sebastian et al., 2017; reproduced here as Fig. S1, as per the copyright policy of $A A C)$. However, in that work, the spurt in the cfu went unnoticed and hence unreported in the paper (Sebastian et al., 2017). When we saw the abnormally high spurt in the cfu of the Msm cells regrowing from the persister population in the presence of MBC of rifampin and moxifloxacin, we rechecked the Mtb data for the Fig. 1A (for rifampin-tolerant/resistant cells) and Fig. S2 (for the moxifloxacin-tolerant/resistant cells) in the paper (Sebastian et al., 2017). Similar to the response of the Msm cells exposed to rifampin and moxifloxacin, the Mtb cells regrowing from the respective persister population, in the presence of MBCs of rifampin and moxifloxacin, also showed unusually high levels of spurt in cfu (Fig. 4A, B and C, D, respectively). The cfu values, pertaining to spurts only, against rifampicin and moxifloxacin, shown here in Fig. 4, were taken from the susceptibility profiles of the Mtb cells to rifampicin and moxifloxacin, respectively, depicted in Fig. S1 [taken from the Fig. 1A (for rifampin-tolerant/resistant cells) and Fig. S2A (for moxifloxacintolerant/resistant cells) of the paper, Sebastian et al., 2017; reproduced here as Fig. S1, as per the copyright policy of AAC)]. Thus, the abnormally high spurt in the Mtb cfu values of the rifampicin-tolerant/resister cells and moxifloxacin-tolerant/resister cells were found to be from 3-fold to 20-fold (Fig. 4A, B and C, D, respectively). Like 

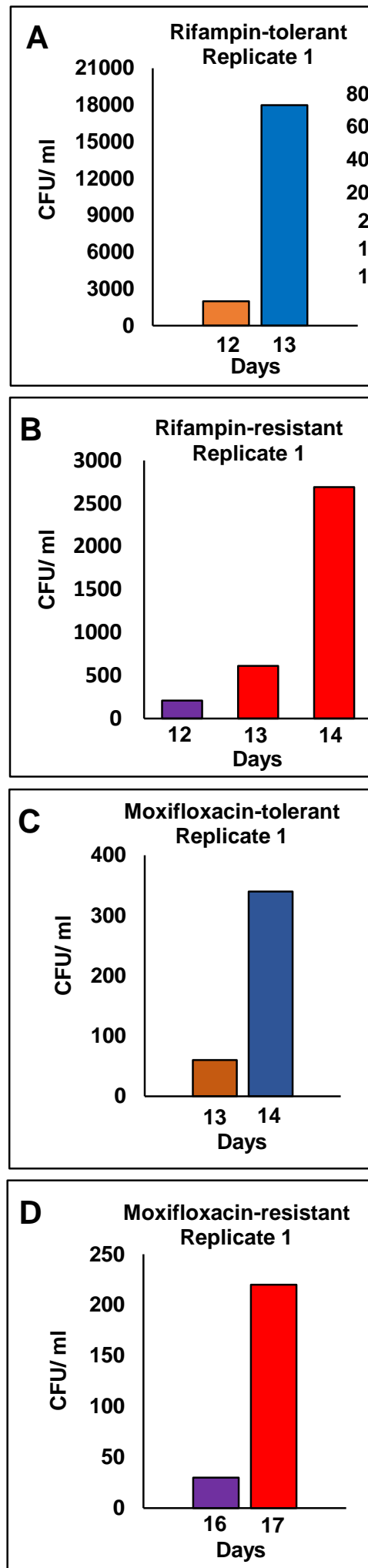

\section{Rifampin-tolerant}

Replicate 2
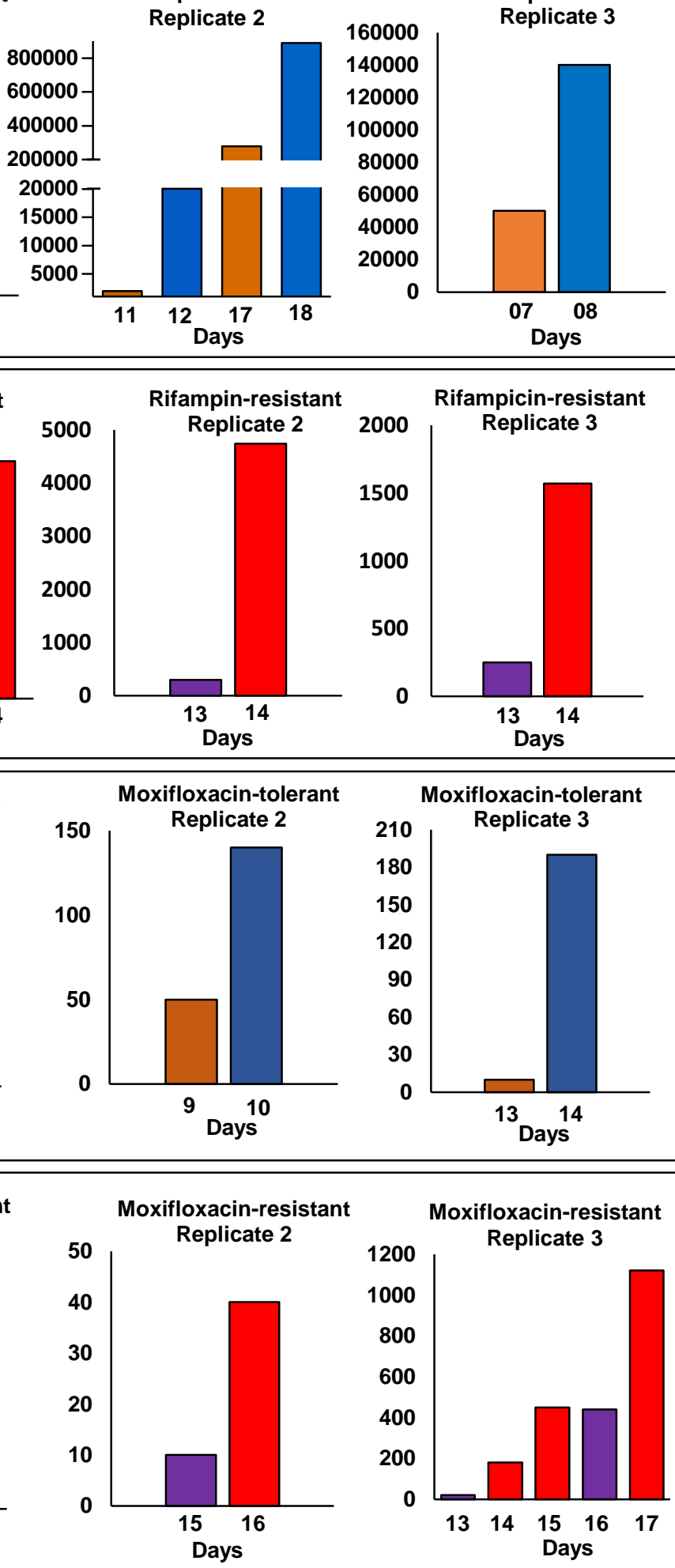

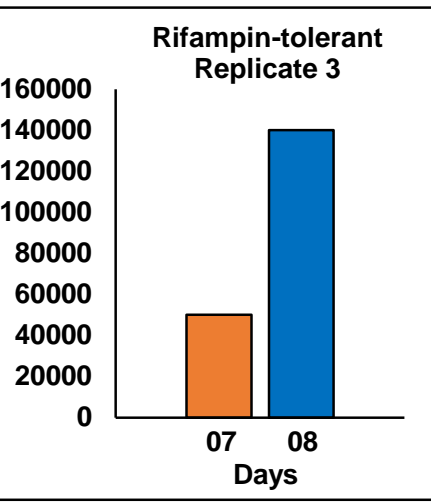

\begin{tabular}{|c|c|}
\hline Day & R1 CFU/ ml \\
\hline 12 & 2000 \\
\hline 13 & $18000(4000)$ \\
\hline Day & R2 CFU/ ml \\
\hline 11 & 2000 \\
\hline 12 & $20000(4000)$ \\
\hline 17 & 280000 \\
\hline 18 & $890000(560000)$ \\
\hline Day & R3 CFU/ ml \\
\hline 07 & 50000 \\
\hline 08 & $140000(100000)$ \\
\hline
\end{tabular}

\begin{tabular}{|c|c|}
\hline Day & R1 CFU/ ml \\
\hline 12 & 210 \\
\hline 13 & $610(420)$ \\
\hline 14 & $2690(1220)$ \\
\hline Day & R2 CFU/ ml \\
\hline 13 & 300 \\
\hline 14 & $4740(600)$ \\
\hline Day & R3 CFU/ ml \\
\hline 13 & 250 \\
\hline 14 & $1570(500)$ \\
\hline
\end{tabular}

\begin{tabular}{|c|c|}
\hline Day & R1 CFU/ ml \\
\hline 13 & 60 \\
\hline 14 & $340(120)$ \\
\hline Day & R2 CFU/ ml \\
\hline 9 & 50 \\
\hline 10 & $140(100)$ \\
\hline Day & $\mathrm{R} 3 \mathrm{CFU} / \mathrm{ml}$ \\
\hline 13 & 10 \\
\hline 14 & $190(20)$ \\
\hline
\end{tabular}

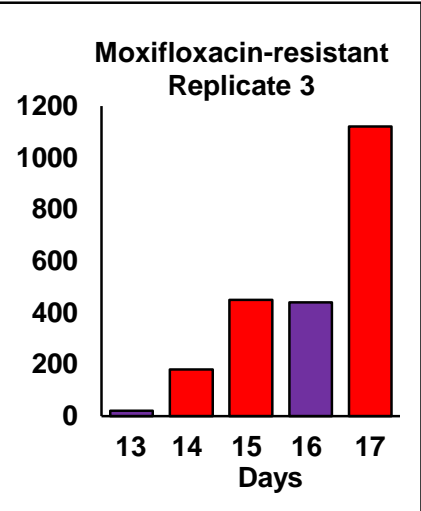

Figure 4. Response of Mycobacterium tuberculosis upon prolonged exposure independently to rifampicin and moxifloxacin. Observed $\mathrm{CFU} / \mathrm{ml}$ (expected $\mathrm{CFU} / \mathrm{ml}$ given in parenthesis considering cell number doubling time as $24 \mathrm{hrs})$ of $M$. tuberculosis cells, during antibiotic exposure to rifampin $(1 \mu \mathrm{g} / \mathrm{ml} ; 10 \mathrm{x}$ MBC) or moxifloxacin ( $1 \mu \mathrm{g} / \mathrm{ml}$; $2 x \mathrm{MBC})$, at every $24 \mathrm{hrs}$ from antibiotic-free and antibiotic-containing $[5 \mu \mathrm{g} / \mathrm{ml}$ rifampicin (50x MBC) or $2 \mu \mathrm{g} / \mathrm{ml}$ moxifloxacin (4x MBC)] Middlebrook $7 \mathrm{H} 10$ agar plates. CFU/ml of rifampintolerant cells, compared to the previous time point, was presented in (A) and of the rifampin-resisters was presented in (B). Similarly, CFU/ml of moxifloxacin-tolerant cells, compared to that of the previous time point, was presented in (C) and that of the moxifloxacin-resisters was presented in (D). The cfu values corresponded to the Fig. 1A (graph for rifampin-exposed M. tuberculosis cells) and Fig. S2 (graph for moxifloxacin-exposed M. tuberculosis cells) from our earlier work (Sebastian et al., 2017), where the unusual spurt in the cfu went unnoticed and unreported by us. Only the time points showing cfu spurt, taken from our earlier published work, have been re-presented here (Sebastian et al, 2017; Copyright @ American Society for Microbiology, Antimicrobial Agents and Chemotherapy, 61, 2017, e01343-16, https://doi.org/10.1128/AAC.01343-16). 
in the case of the emergence of rifampin/moxifloxacin-tolerant/resister Msm cells, the emergence of Mtb rifampin/moxifloxacin-tolerant/resister cells also occurred on different days (Fig. 4A, B and C, D, respectively). These observations indicated that the unexpectedly high-fold in the cfu of the Msm and Mtb cells would not have happened but for some unusual mode of cell growth and division occurring during the regrowth phase of the persister cells during antibiotic exposure.

\section{The Msm cells regrowing from the persister population contain multiple}

nucleoids. The unexpected unusually high fold-increase in the cfu during the regrowth phase could be due to the formation of multiple septae and multiple nucleoids in mother cells followed by their multiple division to generate multiple sister-daughter cells. Another possibility could be mono-nucleoid mother cells undergoing division with lesser mass and cell number doubling time (faster growth and division). A combination of both these phenomena also could cause the high spurt in cfu. We presumed that the second possibility of the cells undergoing faster growth and division is less likely to happen, as sudden change in the generation time has not been reported till date in bacterial systems.

Staining of MLP cells with the DNA-specific dye, Hoechst 33342, showed that $99.60 \pm 0.61 \%$ of the cells at $0 \mathrm{hr}$ (i.e. before antibiotic exposure) were having $\leq 2 \mathrm{n}$ nucleoid content and only $0.39 \pm 0.61 \%$ cells showed $>2 n$ nucleoid content $(n=84)$ (Fig. 5 A-D \& Q). On the contrary, $83.48 \pm 3.91 \%$ cells from the regrowth phase (96 hr) showed $>2 \mathrm{n}$ nucleoid content, with only $16.51 \pm 3.91 \%$ cells having $\leq 2 \mathrm{n}$ nucleoid content ( $n=896$ cells) (Fig. 5 E-P \& R). More images of the multi-nucleoid cells from the $96 \mathrm{hr}$ of exposure are given in Fig. S2. It indicated that the Msm cells regrowing from the rifampin persister population were carrying multiple nucleoids, clearly 


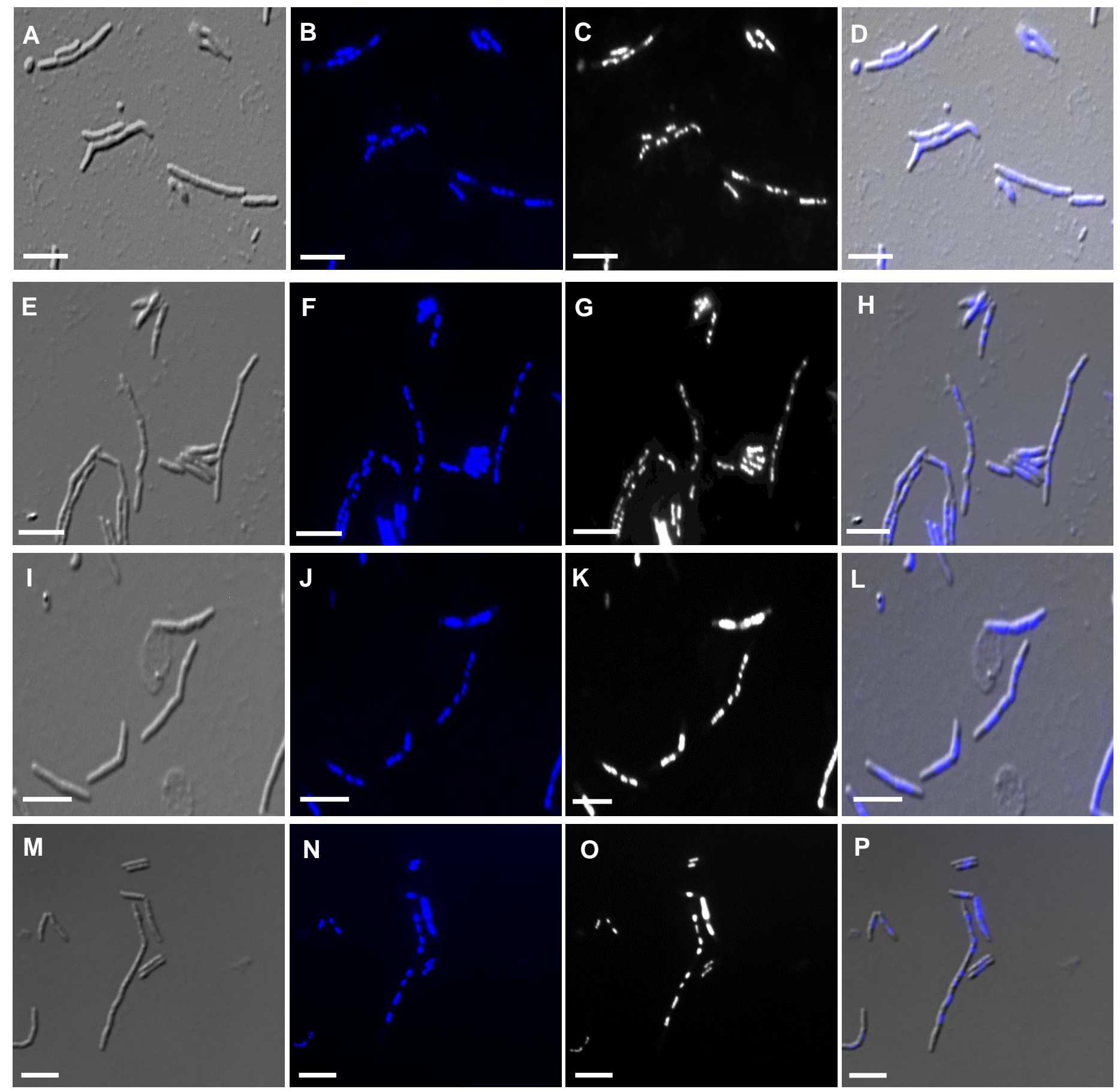

Figure S2. Hoechst staining of $\mathbf{M s m}$ cells regrowing from rifampin persister population. (AP) More images of the cells (96 hr) regrowing from the persister population during antibiotic exposure. (A, E, I, M) DIC images; (B, F, J, N) nucleoid profile; (C, G, K, O) nucleoid profile in bright field; (D, H, L, P) merged images. Scale bar $5 \mu \mathrm{m}$. 
indicating multiple nucleoid divisions, giving scope for future multiple divisions through multiple septation between pairs of nucleoids to generate multiple sister-daughter cells.

\section{The Msm cells regrowing from the persister population possess multiple septae} besides multiple nucleoids. Transmission electron micrographs of the cells, pertaining to $60 \mathrm{hr}, 66 \mathrm{hr}, 72 \mathrm{hr}, 78 \mathrm{hr}, 84 \mathrm{hr}, 90 \mathrm{hr}$ and $96 \mathrm{hr}$, regrowing from the persister population showed mostly elongated cells with multiple condensed nucleoids or multiple septae or with both positioned along the length of the cells and, at times, even at the poles (Fig. 6A-H). We could also observe the presence of shorter-sized cells with mid/polar septum (Fig. 6I, J). Among the total number of cells at $96 \mathrm{hr}, 13.47$ $\pm 3.41 \%$ of cells were septated cells and the remaining $86.52 \pm 3.41 \%$ did not possess septum ( $n=1081)$ (Fig. 6Q). Further, among the total number of cells, $23.39 \pm 9.88 \%$ possessed multiple septae as compared to $76.03 \pm 9.88 \%$ cells with single septum (n $=1081)($ Fig. 6A-C and D, I, respectively; 6R). The atomic force micrographs of 96 hr cells regrowing from the rifampin persister population also revealed the presence of multiple ridges, each of which might be indicative of a septum beneath, which may be sites for multiple divisions in future (Fig. S3), as predicted (Dahl, 2004; Eskandarian et al., 2017).

Among the septated cells ( $n=210$ septated cells), $43.09 \pm 11.14 \%$ of the cells were having polar septum owing to which seemingly anucleated cells also could be observed in the transmission electron micrographs (Fig. 6E, J, S). Further, among the total number of cells, $79.95 \pm 6.55 \%$ cells were having $>2 n$ nucleoid content while the remaining $20.04 \pm 6.55 \%$ possessed $\leq 2 n$ nucleoid content $(n=1081)($ Fig. $6 A-H, T)$. More images of the cells with multiple nucleoids at $96 \mathrm{hr}$ are given in Fig. S4A-H. 


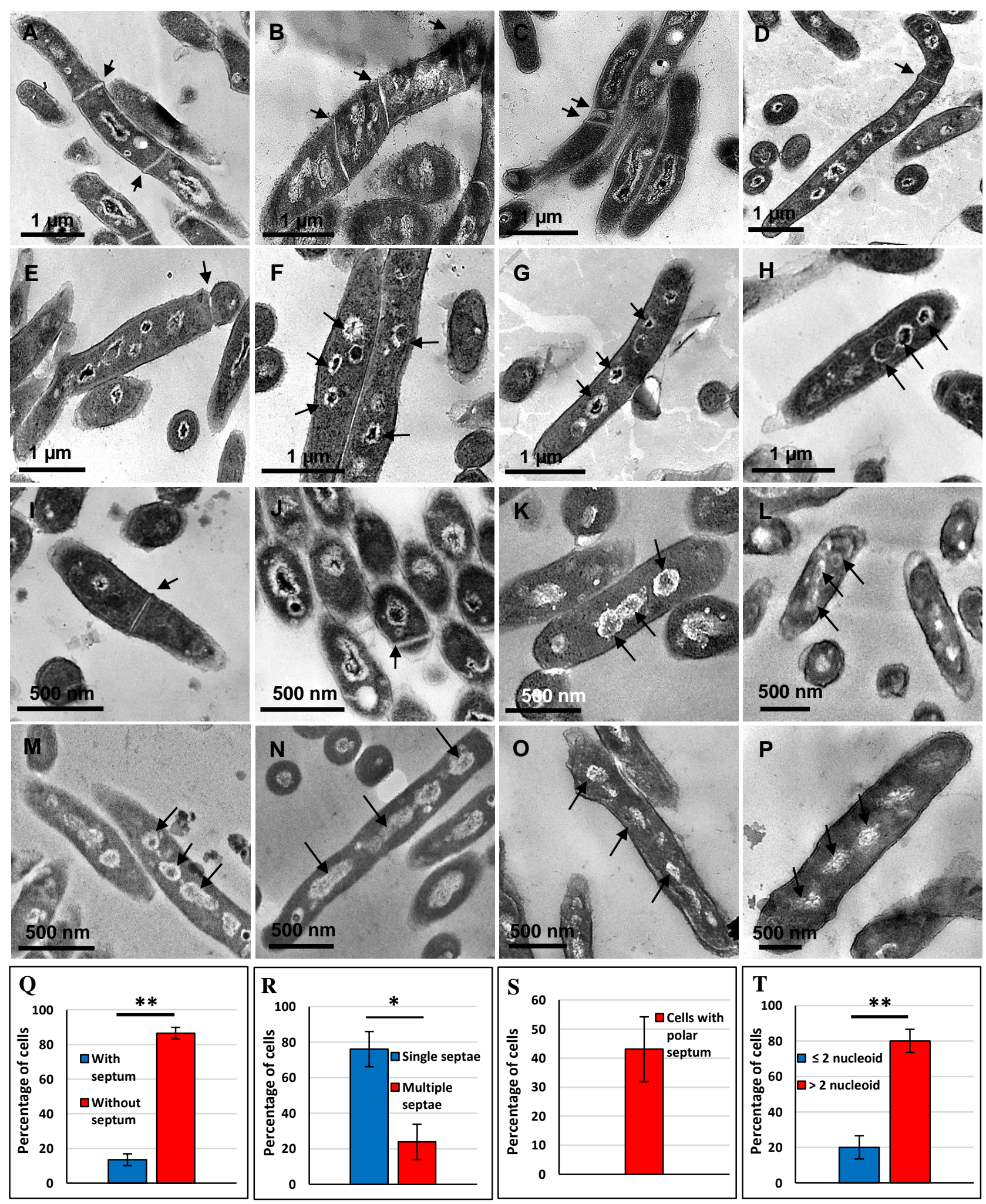

Figure 6. Transmission electron micrographs and quantitation of the Msm cells, regrowing from persister population, taken at different time points during rifampin exposure. (A-H) Elongated cells taken at $96 \mathrm{hr}$; (I, J) Shorter-sized $(\sim 1 \mu \mathrm{m}$ in length) cells at $96 \mathrm{hr}$; (K-P) Regrowing cells taken at: (K) $60 \mathrm{hr}$, (L) $66 \mathrm{hr}$, (M) $72 \mathrm{hr}$, (N) $78 \mathrm{hr},(\mathbf{O}) 84 \mathrm{hr}$, and (P) $90 \mathrm{hr}$. (Q-T) Quantitation of the cells with / without septum, with nucleoid / septae. Most of the cells contain multiple nucleoids and multiple septae. High level of heterogeneity in terms of multiple nucleoids, multiple septae, position of the septae, and size and morphology of the cells could be noted. Arrow heads indicate nucleoid/septae. $n=1081$ cells for $\mathbf{Q}, \mathbf{R}, \mathbf{T}$ and $n=210$ septated cells for $\mathbf{S}$. 
A

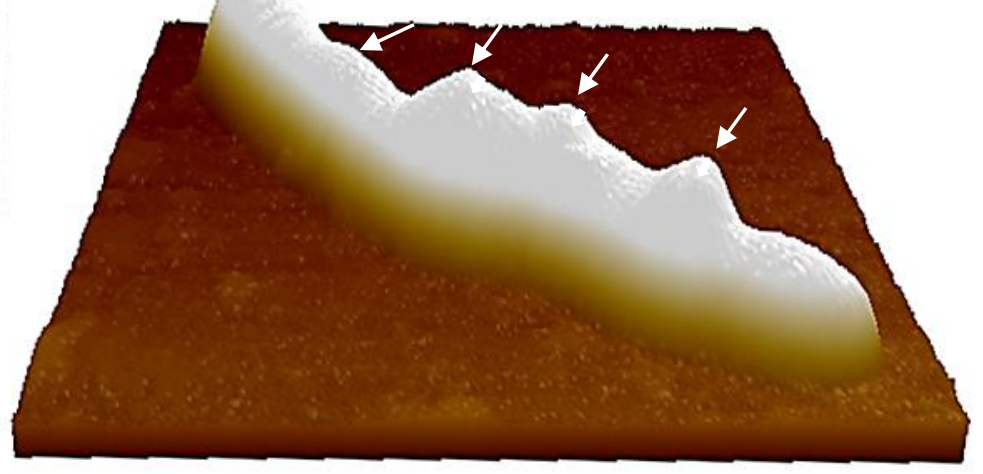

B

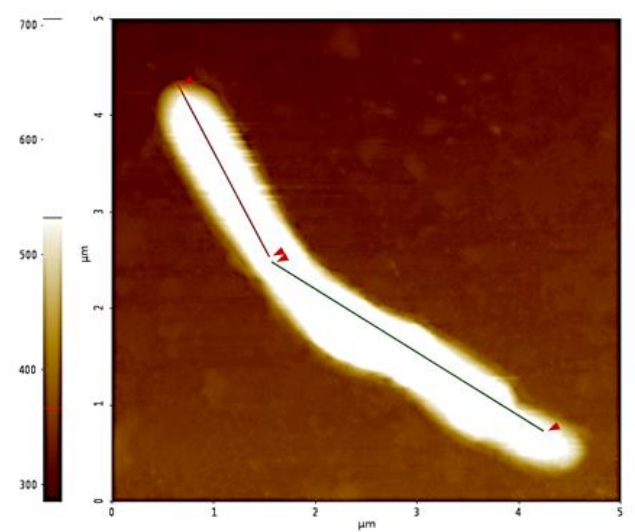

C
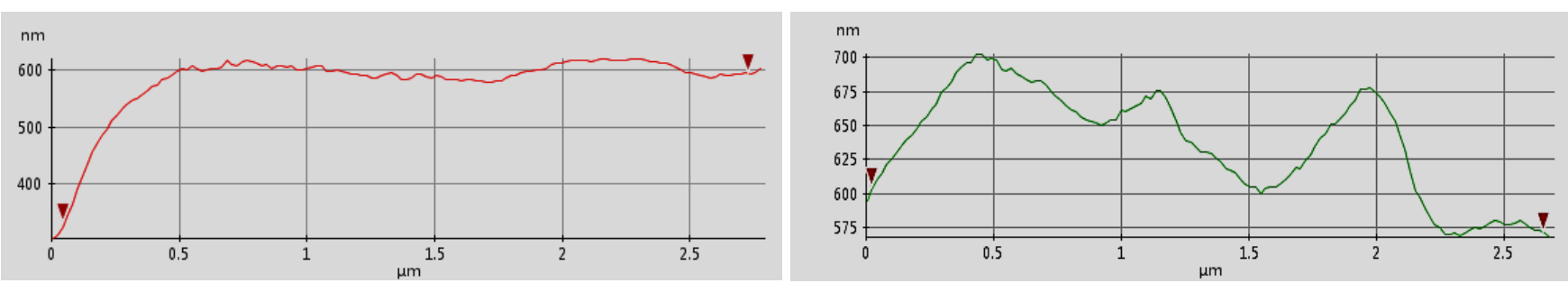

Figure S3. Atomic force micrographs of Mycobacterium smegmatis cells during rifampin exposure. (A). 3D representative image of a cell taken from the $96 \mathrm{hr}$ regrowth phase showing ridges-and-troughs type of cell surface. (B). The flattened image indicates the area selected for making the line profiles (red and green). (C). Line profiles (red and green) representing the ridges-and-troughs type of cell surface. Arrow heads indicate circular waveform troughs, probably corresponding to multiple septae beneath. 


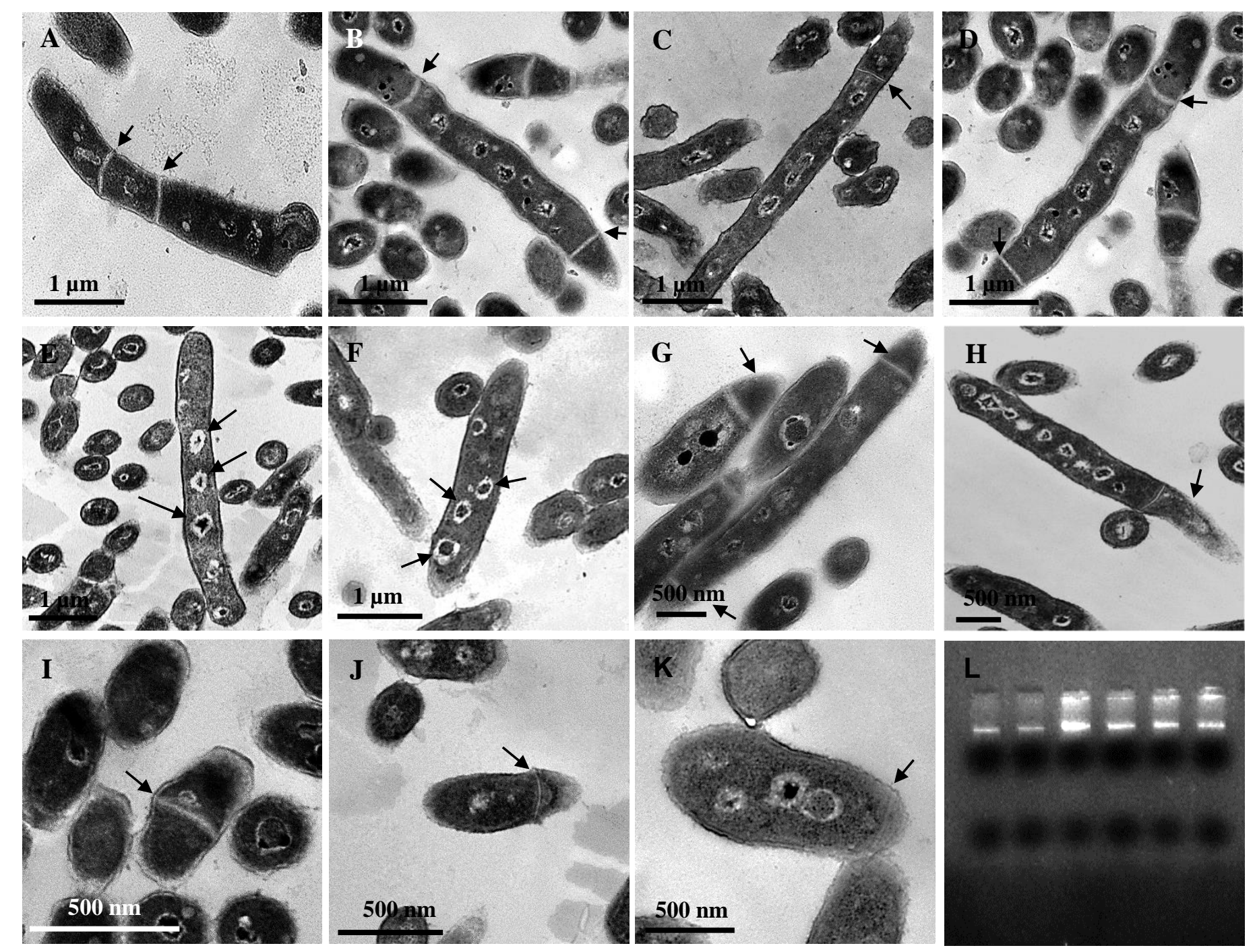

Figure S4. Transmission electron micrographs of the Msm cells, regrowing from persister population, at $96 \mathrm{hr}$. Cells with: (A, B) multiple septae, (C, D) polar septum with nucleoids, (E, F) multiple nucleoids. (G, H) Cells with anucleated portions due to polar septation. (I-K) Mid/polar septation in shorter-sized cells ( 1 $\mu \mathrm{m}$ in length). (L) Genomic DNA profile obtained from the cells from six different colonies taken from the $96 \mathrm{hr}$ sample, showing intact genome, thereby confirming lack of genome fragmentation. A high level of heterogeneity in terms of multiple nucleoids, multiple septae, septal position, size and morphology could be noted. Arrow heads indicate nucleoid/septae/ anucleated cell ( $n=>1081$ cells). 
Shorter-sized cells ( 1 $\mu \mathrm{m}$ in length) with mid/polar septum could also be observed (Fig. S4 I-K). Genomic DNA profile obtained from the cells from six different colonies taken from the $96 \mathrm{hr}$ sample, showed intact genome, thereby confirming lack of genome fragmentation in the cells (Fig S4 L). Thus, the intact genomic DNA isolated from the $96 \mathrm{hr}$ cells suggested that the cells with multiple nucleoid-type images should not be misconstrued as cells with fragmented nucleoids. Further, nucleoid fragmentation was ruled out as it would not have given the unusual unexpectedly high spurt in the cfu during division as the cells with fragmented nucleoid would be unviable as single cells and hence would not generate progeny cells.

Cellular heterogeneity in the regrowing population. Among the cells in the regrowing population, a high level of heterogeneity in terms of cells with different number of nucleoids, different number of septae, differences in the septal position, differences in lengths and morphology could be noted. We examined whether such level of heterogeneity was developed over a period of the growth and division of the cells in the regrowing population. The ultrastructural images of the cells in the regrowing population, at every $6 \mathrm{hrs}$ during the regrowing phase from $60 \mathrm{hr}$ to $90 \mathrm{hr}$, showed progressive increase in cell-length with increase in nucleoid content (Fig. 6KP). Some of the cells showed elongated nucleoids (Fig. 6M, N), like in the bacterial cells that undergo nucleoid replication and segregation (Lin et al., 1997; Webb, 1997; Van helvoort et al., 1998; Ben-Yehuda et al., 2003; Errington et al., 2005; Zhang et al., 2009; Fisher et al., 2013; Gorle et al., 2017). In bacterial karyokinesis during cell division, the cells elongate to twice their length to form the sister-daughter cells and accommodate the replicating and segregating nucleoids (Sargent, 1975; Donachie et al., 1976; Donachie and Begg, 1989; Sharpe et al., 1998). Further, repeated 
karyokinesis (nucleoid replication and segregation) without cytokinesis (septation) causes elongation or filamentation of the cells (Adler et al., 1968; Spratt, 1975; Moya et al., 1998, Weiss et al., 1999; Rosenberger and Finlay, 2002; Chauhan et al., 2006; Justice et al., 2006; reviewed in Justice et al., 2008; Moller et al., 2013; Muckl et al., 2018). Therefore, with $\sim 3-4 \mu \mathrm{m}$ as the average length of a non-dividing Msm MLP cell (Vijay et al., 2014b), formation of multiple nucleoids necessitated increase in celllength anywhere from $\sim 8 \mu \mathrm{m}$ ( twice their average cell-length) to $20 \mu \mathrm{m}$ ( $~ 5$ times their average cell-length), as observed from the images. From the cell-length of $\sim 3-4 \mu \mathrm{m}$ of the cells at $0 \mathrm{hr}$ of exposure (MLP cells), the cell-length progressively increased till 84 hr and reached a maximum by 96 hr (Fig. 7; Fig. S5). The phenotype observed in the DIC images correlated with the progressively elongated phenotype found in the transmission electron micrographs of the cells from the earlier hours of exposure to 96 hr (compare Fig. 7, Fig. S5 with Figure 6K-P). By 102 hr, a sudden drop in the celllength, to almost equal to that of the cells at $0 \mathrm{hr}$ (MLP cells), was observed (Fig. 7A, B and Fig. S5). This drop might be indicative of the division of the multinucleated, multi-septated cells into mononucleated individual sister-daughter cells.

No nutritional stress during the late hrs of regrowth. During the late hrs of growth, wherein stationary phase related nutritional stress sets in, the Msm / M. bovis BCG cells have been found to be shorter in size (Smeulders et al., 1999; Thanky et al., 2007; Markova et al., 2012; Wu et al., 2016; Dow and Prisic, 2018). Therefore, the drop in the cell-length of the cells in the $102 \mathrm{hr}$ culture might be due to nutritional stress induced change into shorter size. However, the levels of glycerol in the medium up to $102 \mathrm{hr}$ were comparable to its levels in the beginning of the culture, with very little levels utilised, indicating that there was no depletion of glycerol levels, which might 

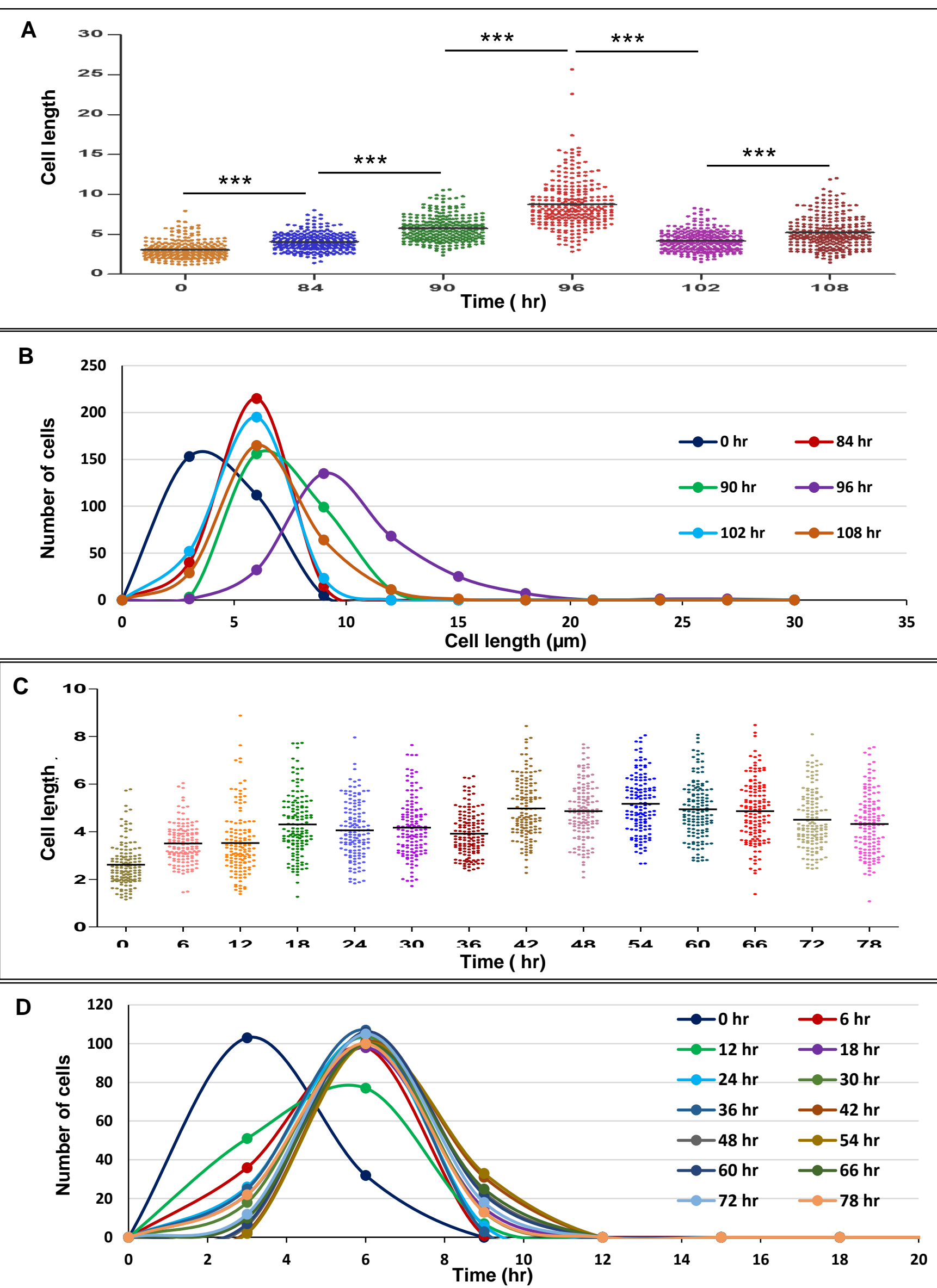

Figure 7. The determination of cell-lengths and cell-length distribution of the Msm cells during the entire period of exposure to rifampin. (A) The cell-lengths and their distribution among the cells: (A, B) in the late regrowth phase ( $84 \mathrm{hr}$ to $108 \mathrm{hr}$ ), in comparison to those of the cells at $0 \mathrm{hr}$ (MLP cells); (C, D) during the entire period of $0 \mathrm{hr}$ to $78 \mathrm{hr}$, spanning the killing ( $0 \mathrm{hr}$ to $36 \mathrm{hr}$ ), persistence phase ( $36 \mathrm{hr}$ to $54 \mathrm{hr}$ ) and early regrowth phases (54 hr to $78 \mathrm{hr})$ of exposure to rifampin $(n=1890)$. 

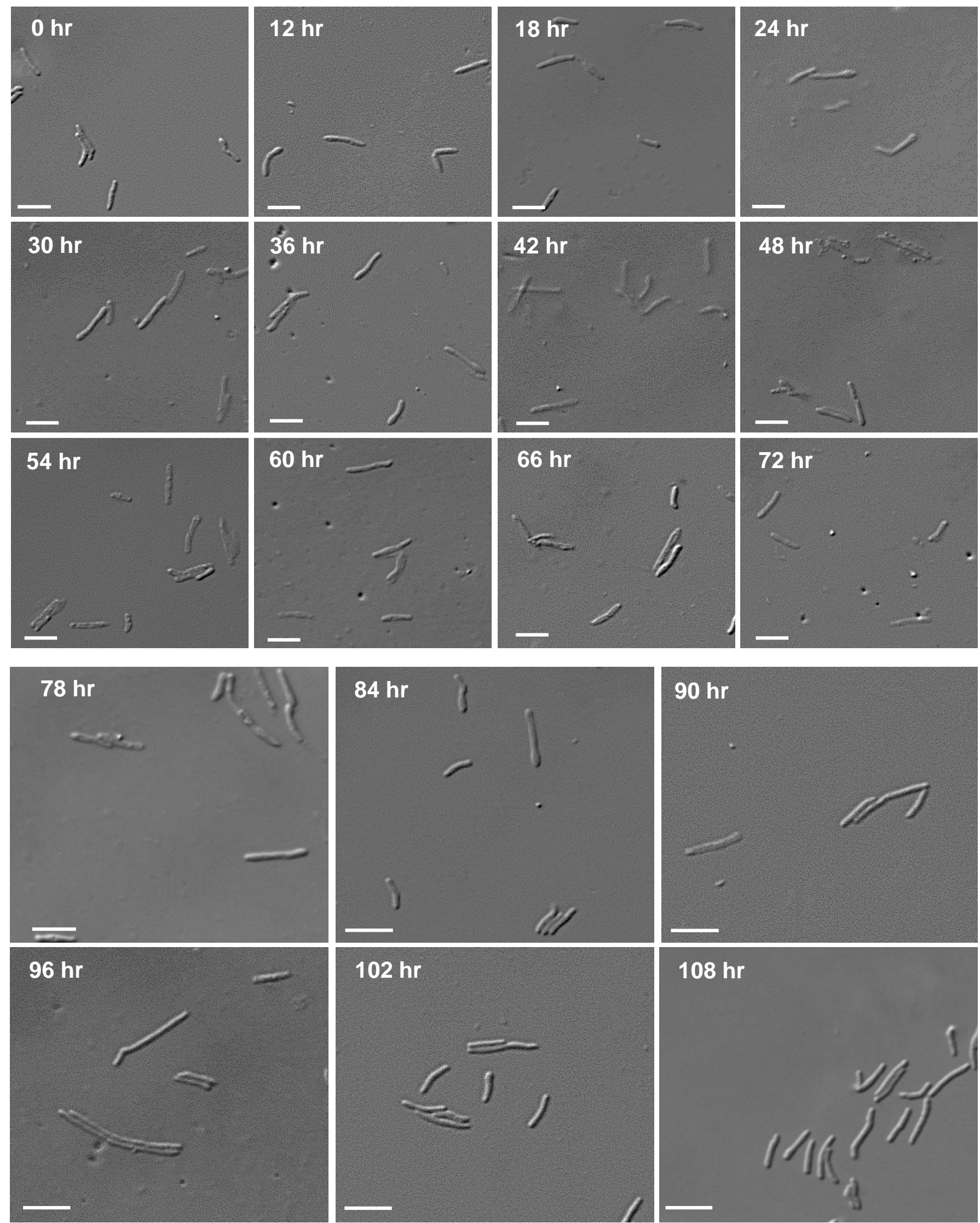

Fig S5. DIC images of the Msm cells at different time points during rifampin exposure. The cells were taken at every $6 \mathrm{hr}$ interval from the rifampin-exposed population to determine the cell-lengths. DIC images of the cells during the killing phase $(0 \mathrm{hr}$ to $36 \mathrm{hr})$, persistence phase ( $36 \mathrm{hr}$ to $54 \mathrm{hr}$ ), and regrowth phase ( $54 \mathrm{hr}$ to $108 \mathrm{hr}$ ). Scale bar, $5 \mu \mathrm{m}$. 
have otherwise caused nutritional stress and consequential reduced-size phenotype (Fig. S6). The low levels of glycerol utilisation was expected as the entire duration of the culture from the start $(0 \mathrm{hr})$ to $54 \mathrm{hr}$ involved killing phase followed by the persistence phase where there would not have been any growth or division of the cells in the continued presence of rifampin (see Figure 1A). Subsequently, during the late regrowth phase from $102 \mathrm{hr}$, the glycerol levels steeply decreased, which correlated with the increase in the $\mathrm{OD}_{600 \mathrm{~nm}}$ indicating glycerol utilisation for cell growth and division (Fig. S6). These observations ruled out the possibility of any nutritional stress which otherwise would have been suspected to be the cause for the reduction in the size of elongated cells into normal-sized cell size at $102 \mathrm{hr}$ of exposure. Thus, the reduction in the length of the cells at $102 \mathrm{hr}$, as compared to the elongated cells at 96 hr (see Fig. 7A, B, Fig. S4), seemed most likely to be due to the division of the multinucleated, multi-septated cells into mononucleated individual sister-daughter cells.

Time-lapse live-cell imaging of multiple constriction. Multiple septation and division was further monitored in live cells using time-lapse imaging of the multiple constriction of the cells from $90 \mathrm{hr}$ till $102 \mathrm{hr}$ of antibiotic exposure in order to confirm the observed phenomenon of the formation of multi-septated, multi-nucleated cells. Multiple constriction could be clearly observed among the regrowth phase cells wherein the daughter cells, which were generated by multiple constriction, again underwent multiple constriction and produced more than two sister-daughter cells in single division (Fig. 8 and Video S1). Tracking the division lineage of the cells showed multiple constriction of mother cells and of the sister-daughter cells that were produced from the multiple-constricted mother cells (Fig. S7 traced from Video S1). 

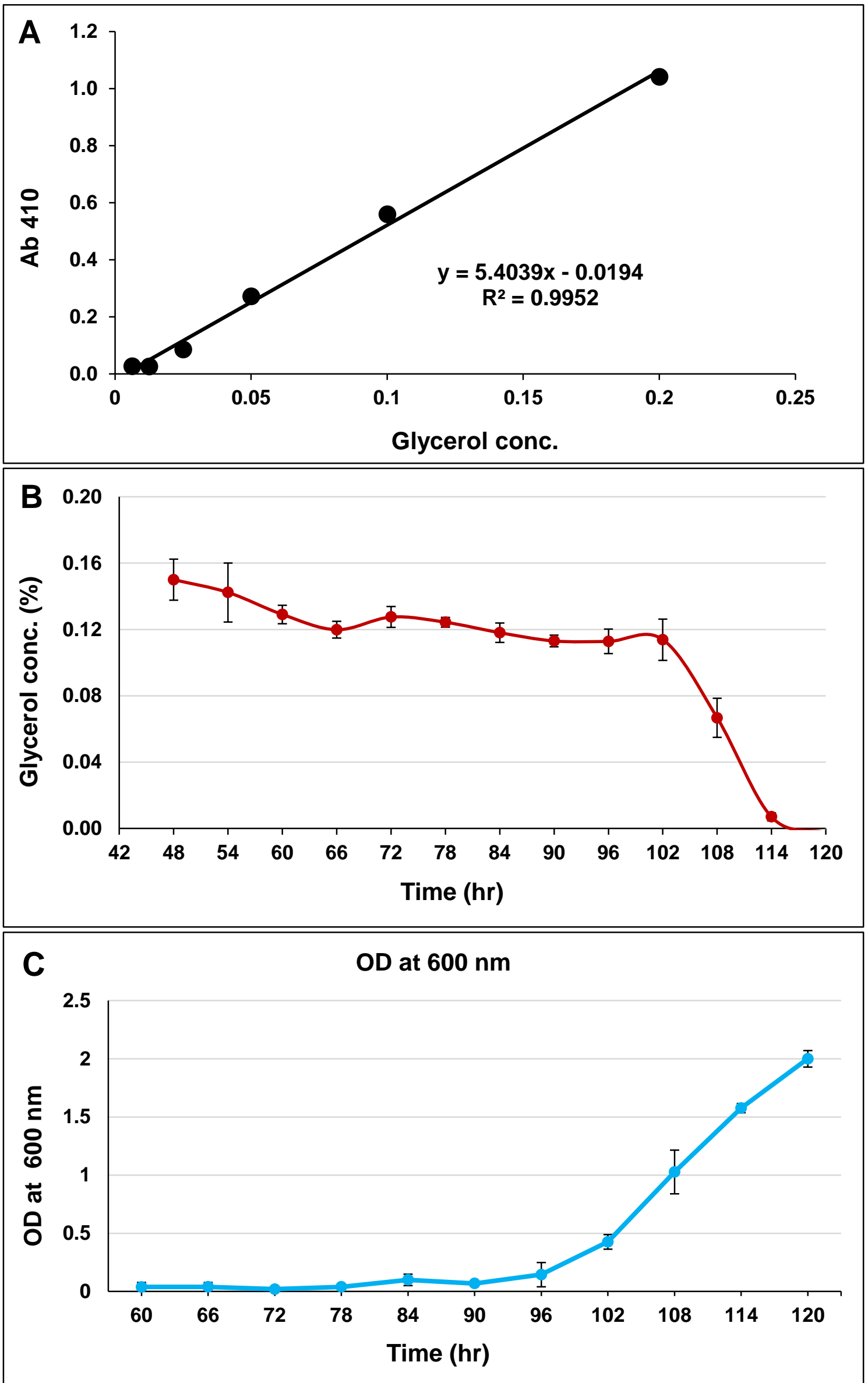

Fig S6. Estimation of glycerol in the Msm cultures during the regrowth phase. (A) Standard curve for glycerol estimation with different concentrations of glycerol. (B) The concentration of glycerol present in the culture at different time points during the exposure of the cells to rifampin. (C) Growth of the cells measured by observing the cell density at $\mathrm{OD} 600_{\mathrm{nm}}$ at different time points. 


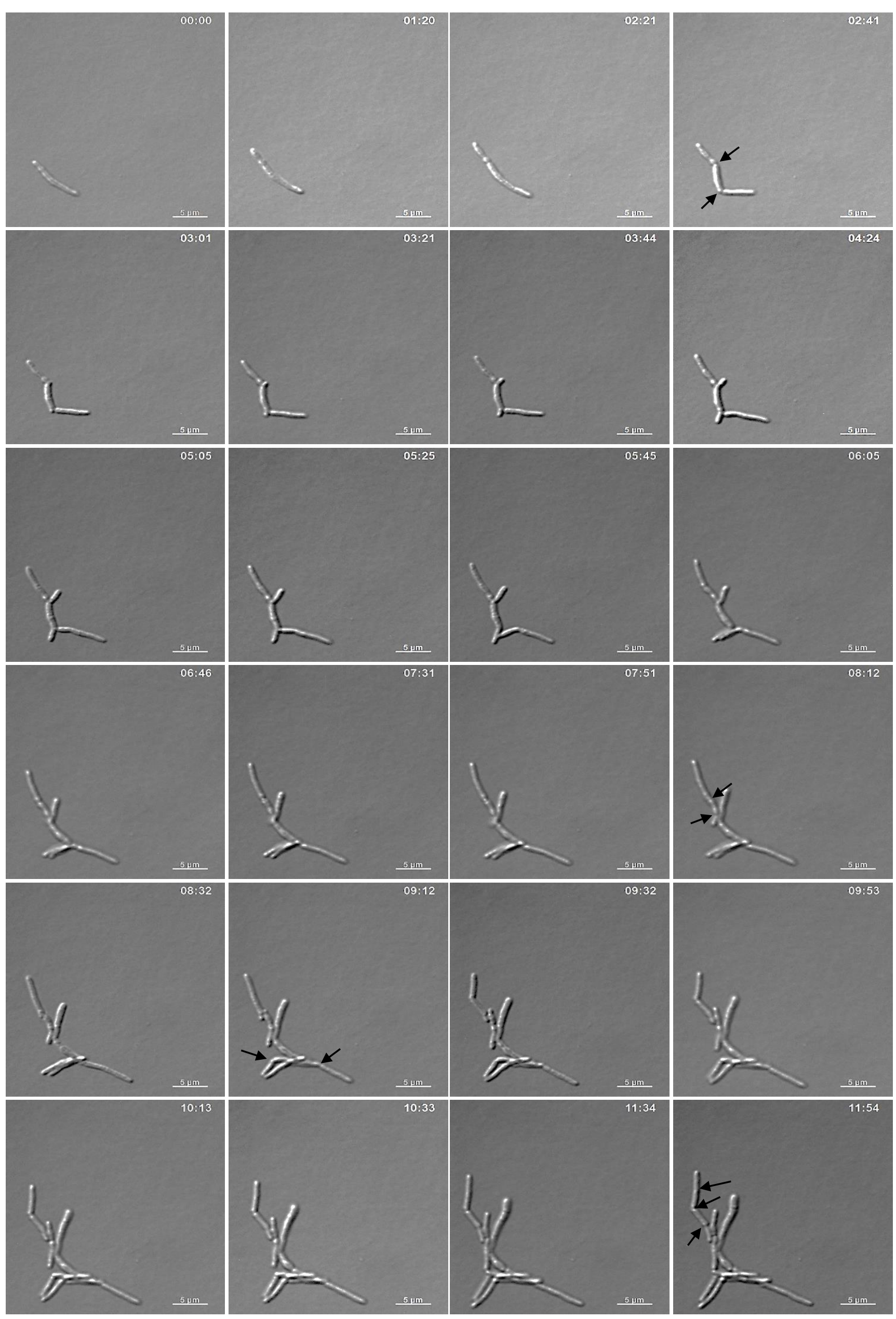

Figure 8. Live-cell time-lapse images of the cells from $96 \mathrm{hr}$ regrowth phase. The cells show multiple constriction. Arrowhead indicated consriction. The images were from video S1. 


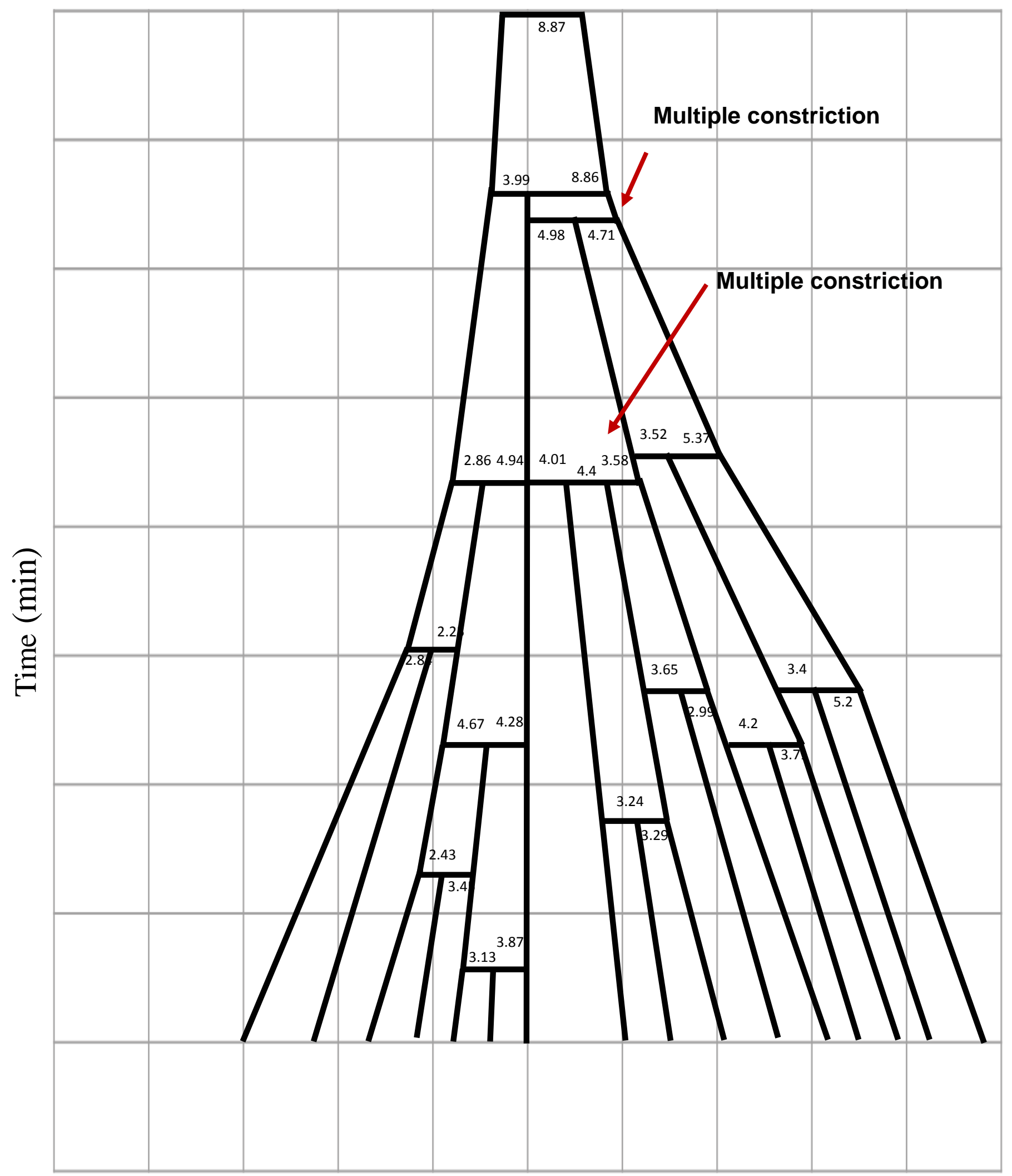

Fig S7. The lineage of the formation of $M$. smegmatis sister-daughter cells stressed with $5 \mu \mathrm{g} / \mathrm{ml}$ rifampin for $12 \mathrm{hrs}$. The growth and division lineage was traced from the images of time-lapse microscopy shown in the Video S1. The zero-time point does not correlate with the birth of the starting mother cell. Red arrows indicate the occurrence of multiple constriction. The cell lengths were drawn to approximation, not to scale. 
Regrowth phase cells were rifampin-resisters with mutation at RRDR. Regrowth and division in the presence of antibiotic normally occurs in the cells that have gained antibiotic resistance through ROS-mediated mutagenesis (Dwyer et al., 2009; Kohanski et al., 2010; Li et al., 2015; Sebastian et al., 2017; Hoeksema et al., 2018; Jin et al., 2018). Therefore, we wanted to find out whether the observed multiple division, resulting in sudden increase in the cfu of the regrowth phase population, was brought about by the rifampin-resister population carrying RRDR genetic mutation or by the rifampin-tolerant population lacking RRDR mutation. For this purpose, the colonies from the $84 \mathrm{hr}, 90 \mathrm{hr}, 96 \mathrm{hr}$ and $102 \mathrm{hr}$ of the regrowth phase from the rifampin-free plates were patched onto rifampin-containing plate (3x MBC; $125 \mu \mathrm{g} / \mathrm{ml}$ rifampin). All the colonies from the rifampin-free plates from the four time points grew on rifampin-containing plate, indicating that all the colonies from the regrowth phase had come from the rifampin-resistant mutants (Fig. 9A). This provided evidence that the cells with multiple septation might have been the resister population.

Although the cells had grown on rifampin plates, there was a possibility that they could be phenotypic or genotypic resisters. Sequencing of the RRDR of the genomic DNA from the $96 \mathrm{hr}$ colonies from the rifampin plates, performed using RRDR primers (Table S1), showed mutations in all the colonies, confirming that these were indeed the cells that were carrying genetic mutation at the RRD of the rpo $B$ gene, which conferred resistance to rifampin (Fig. 9B). Sequencing of the colonies, from the rifampin-free plate, which were originally obtained from rifampin-containing liquid culture, also possessed mutation in the RRDR (Fig. 9C). This confirmed that the observed mutations were already present in the cells in the rifampin-containing liquid culture itself and were not generated on the selection plate containing rifampin. 

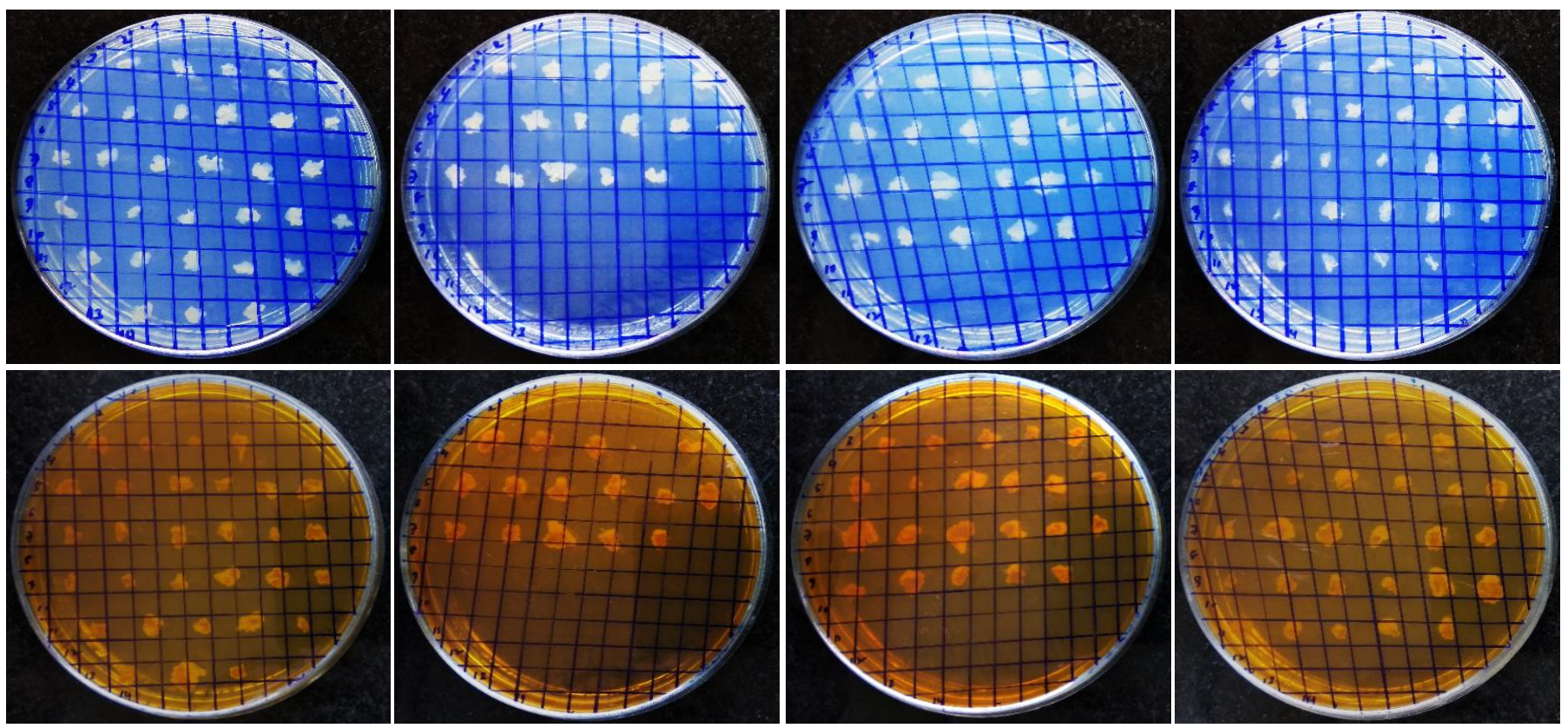

B

Leu Ser Gln Phe Met Asp Gln Asn Asn Pro Leu Ser Gly Leu Thr His Lys Arg Arg Leu Ser Msm WT : 5'- CTG TCG CAG TTC ATG GAC CAG AAC AAC CCG CTG TCG GGT CTG ACC CACAAG CGT CGT CTT TCG - 3' 96-RR-S1-1 : 5'- CTG TCG CAG TTC ATG GAC CAG AAC AAC CCG CTG TCG GGT CTG ACC TAC AAG CGT CGT CTT TCG - 3' 96-RR-S1-2 : 5'- CTG TCG CAG TTC ATG GAC CAG AAC AAC CCG CTG TCG GGT CTG ACC TAC AAG CGT CGT CTT TCG - 3' 96-RR-S1-3 : 5'- CTG TCG CAG TTC ATG GAC CAG AAC AAC CCG CTG TCG GGT CTG ACC TAC AAG CGT CGT CTT TCG - 3'

96-RR-S2-1 : 5'- CTG TCG CAG TTC ATG GAC CAG AAC AAC CCG CTG TCG GGT CTG ACO CGQ AAG CGT CGT CTT TCG - 3' 96-RR-S2-2 : 5'- CTG TCG CAG TTC ATG GAC CAG AAC AAC CCG CTG TCG GGT CTG ACC CGC AAG CGT CGT CTT TCG - 3' 96-RR-S2-3 : 5'- CTG TCG CAG TTC ATG GAC CAG AAC AAC CCG CTG TCG GGT CTG ACC CGC]AAG CGT CGT CTT TCG - 3'

96-RR-S3-1 : 5'- CTG TCG CAG TTC ATG GAC CAG AAC AAC CCG CTG TCG GGT CTG ACC CGCAAG CGT CGT CTT TCG - 3' 96-RR-S3-2 : 5'- CTG TCG CAG TTC ATG GAC CAG AAC AAC CCG CTG TCG GGT CTG ACC CGC AAG CGT CGT CTT TCG - 3' 96-RR-S3-3 : 5'- CTG TCG CAG TTC ATG GAC CAG AAC AAC CCG CTG TCG GGT CTG ACC CGC]AAG CGT CGT CTT TCG - 3'

C Msm WT : 5'- CTG TCG CAG TTC ATG GAC CAG AAC AAC CCG CTG TCG GGT CTG ACC CACAAG CGT CGT CTTTCG- 3' 96-RR-S4-1 : 5'- CTG TCG CAG TTC ATG GAC CAG AAC AAC CCG CTG TCG GGT CTG ACC CCC AAG CGT CGT CTT TCG - 3' 96-RR-S4-2 : 5'- CTG TCG CAG TTC ATG GAC CAG AAC AAC CCG CTG TCG GGT CTG ACC CGC AAG CGT CGT CTT TCG - 3' 96-RR-S4-3 : 5'- CTG TCG CAG TTC ATG GAC CAG AAC AAC CCG CTG TCG GGT CTG ACC TAC AAG CGT CGT CTT TCG - 3'

96-RR-S5-1 : 5'- CTG TCG CAG TTC ATG GAC CAG AAC AAC CCG CTG TCG GGT CTG ACC TAC AAG CGT CGT CTT TCG - 3' 96-RR-S5-2 : 5'- CTG TCG CAG TTC ATG GAC CAG AAC AAC CCG CTG TCG GGT CTG ACC TAC AAG CGT CGT CTT TCG - 3' 96-RR-S5-3 : 5'- CTG TCG CAG TTC ATG GAC CAG AAC AAC CCG CTG TCG GGT CTG ACC TAC AAG CGT CGT CTT TCG - 3'

96-RR-S6-1 : 5'- CTG TCG CAG TTC ATG GAC CAG AAC AAC CCG CTG TCG GGT CTG ACC CGCAAG CGT CGT CTT TCG - 3' 96-RR-S6-2 : 5'- CTG TCG CAG TTC ATG GAC CAG AAC AAC CCG CTG TCG GGT CTG ACC CGC AAG CGT CGT CTT TCG - 3' 96-RR-S6-3 : 5'- CTG TCG CAG TTC ATG GAC CAG AAC AAC CCG CTG TCG GGT CTG ACC CGCAAG CGT CGT CTT TTG- 3'

Figure 9. Colony patching of the cells taken from rifampin-free plate from different time points during the regrowth phase into rifampin-containing plate. (A). Colonies, taken from the $84 \mathrm{hr}, 90 \mathrm{hr}, 96 \mathrm{hr}$ and $102 \mathrm{hr}$ from the rifampin-free master plates, were patched onto rifampin-free plates (top panel in blue colour) and rifampin $(125 \mu \mathrm{g} / \mathrm{ml})$ plates (lower panel in orange colour). (B, C). Comparison of the RRDR sequence of the wild-type genome with the RRDR sequence of the cells from the: (B) rifampin plates and (C) rifampin-free plates. In both (B) and (C), $n=3$ experimental samples, each with biological replicates. 
We and other groups have shown the generation of reactive oxygen species (ROS) in the antibiotic-exposed Mtb cells (Grant et al., 2012; Piccaro et al., 2014; Nandakumar et al., 2014) and in the rifampin/moxifloxacin-exposed Mtb persister cells (Sebastian et al., 2017) and Msm persister cells (Swaminath, 2017). Consistent with this findings, we could detect high levels of hydroxyl radical specific hydroxyphenyl fluorescein (HPF) fluorescence from the persister phase cells (48 hr onwards) (Fig. S8). The HPF fluorescence steadily decreased till $90 \mathrm{hr}$, during the emergence of rifampin-resistant mutant cells in the regrowth phase, and subsequently plateaued (Fig. S8). It indicated the generation of hydroxyl radical in the persister phase cells and the decline of the same in the regrowth phase cells once the cells had gained resistance, and become free from the antibiotic stress, as reported by us for rifampinexposed Mtb cells (Sebastian et al., 2017) and moxifloxacin-stressed Msm cells (Swaminath, 2017). The reciprocal decline/rise nature of the profile of cfu and HPF fluorescence indicated that the HPF fluorescence, indicative of hydroxyl radical generation, was highest when the cells were in the persister phase, and that the hydroxyl radical generation declined when the cells started regrowth and division after gaining relief from the rifampin stress by acquiring rifampin resistance through RRDR mutation (Fig. 9B, C and Fig. S8).

\section{Naturally formed rifampin-resisters do not show sudden spurt in cell division. It} may be recalled here that it was the rifampin-resistant mutants, which emerged from the persistence phase through the multiple division of multi-septated, multi-nucleated elongated cells, showed the phenomenon of sudden abnormally high spurt in division. Therefore, we wanted to verify whether the phenomenon would be shown by the rifampin-resistant mutants, which arise naturally from the mid-log population and not 


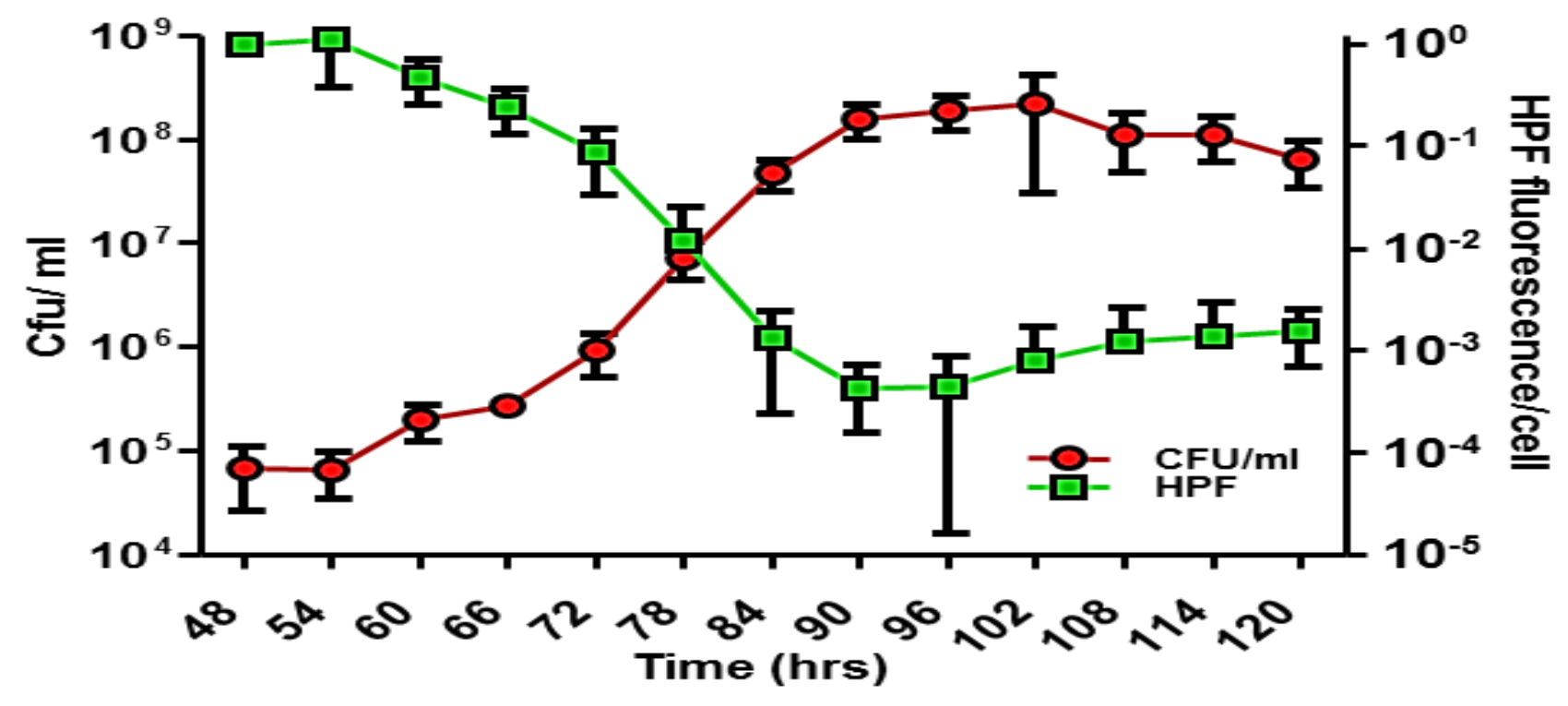

Fig S8. HPF fluorescence profile of the cells in the persister phase followed by regrowth phase after normalisation with their respective CFU. The hydroxyl radical levels were high during the persister phase and they declined when the cells have entered regrowth phase after acquiring RRDR mutation and becoming free from the antibiotic stress. 
from the rifampin persister population. For this purpose, we checked whether the rifampin-resistant genetic mutants, which were selected from the mid-log population against rifampin by direct plating, and therefore not emerged from persister population, would show sudden increase in the cfu when re-exposed to rifampin for prolonged duration. All the rifampin-resisters, which were selected by plating the MLP culture on 3x MBC rifampin plate, possessed mutation in the RRDR (Fig. S9A). Upon culturing these mutants in $25 \mu \mathrm{g} / \mathrm{ml}$ rifampin-containing liquid medium and plating on antibioticfree plate, the cells showed the expected 2 -fold increase in the cfu within 3 hrs of cell number doubling time. It indicated that unlike the rifampin-resistant mutants formed from the persister population, the rifampin-resistant mutant cells from the MLP culture underwent normal cell division without any spurt (Fig. S9B, C). Thus, the abnormally high spurt in the cell division was a unique cell division behaviour of the ROS-induced rifampin-resistant mutants from the rifampin persister population only.

\section{Heterogeneity of regrowing cells prevents molecular analysis of the} mechanism. In order to understand the molecular mechanism that drives the formation of multi-septated, multi-nucleated cells and consequential sudden spurt in cell division, we isolated and purified total RNA of high integrity from the regrowing population of cells from the $96 \mathrm{hr}$ time point and performed quantitative RT-PCR. The genes selected for the quantitative PCR included those involved in cell division, DNA repair, error-prone DNA polymerisation, SOS regulon, oxidative stress response, and few other controls. However, we got widely varying results from multiple biological replicates of the total RNA (data not shown). We presume that this variation could be due to the cellular heterogeneity of the regrowing population revealed by the TEM images which showed wide differences in the proportions of the cells with multiple 
Msm WT : 5'- CTG TCG CAG TTC ATG GAC CAG AAC AAC CCG CTG TCG GGT CTG ACC CACAAG CGT CGT CTT TCG - 3'

NR-1 : 5'- CTG TCG CAG TTC ATG GAC CAG AAC AAC CCG CTG TCG GGT CTG ACC CGCAAG CGT CGT CTT TCG - $3^{\prime}$

NR-2 : 5' - CTG TCG CAG TTC ATG GAC CAG AAC AAC CCG CTG TCG GGT CTG ACC CGC AAG CGT CGT CTT TCG - $3^{\prime}$

NR-3 : 5' - CTG TCG CAG TTC ATG GAC CAG AAC AAC CCG CTG TCG GGT CTG ACC CGC AAG CGT CGT CTT TCG - 3'

NR-4 : 5' - CTG TCG CAG TTC ATG GAC CAG AAC AAC CCG CTG TCG GGT CTG ACC TAC AAG CGT CGT CTT TCG - 3'

NR-5 : 5' CTG TCG CAG TTC ATG GAC CAG AACAAC CCG CTG TCG GGT CTG ACC CGC AAG CGT CGT CTT TCG - 3'

NR-6 : 5'- CTG TCG CAG TTC ATG GAC CAG AAC AAC CCG CTG TCG GGT CTG ACC CGC AAG CGT CGT CTT TCG - $3^{\prime}$
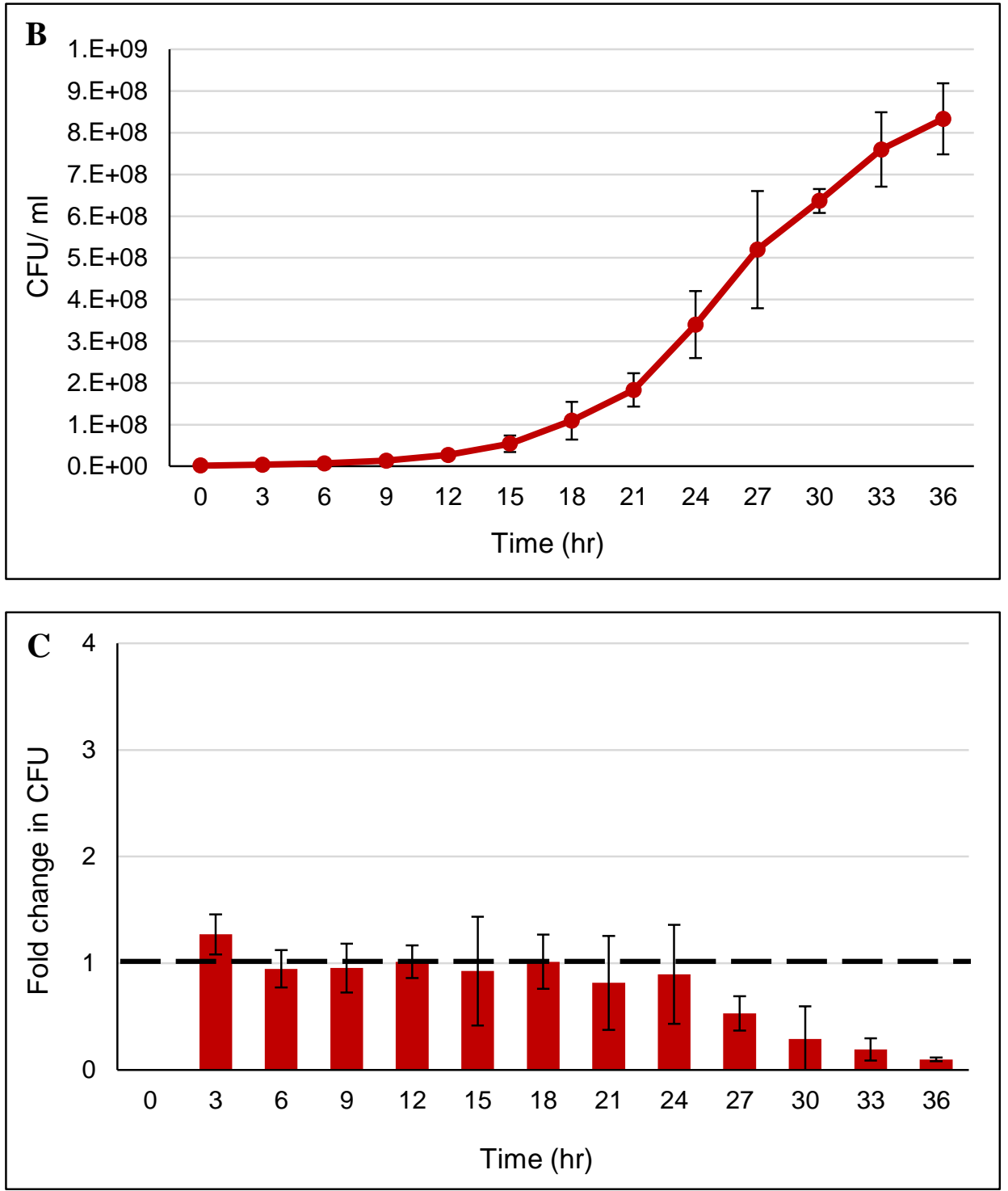

Fig S9. Growth, division and fold-change in the cfu of the rifampin-resistant mutants that were directly selected from the MLP culture. (A) RRDR mutations in the six rifampin-resistant mutants selected from the MLP culture. (B) Growth curve of one of the six Msm rifampin-resistant mutants when cultured in the presence of $25 \mu \mathrm{g} / \mathrm{ml}$ rifampin. (C) Fold-change in the cfu of the rifampin-resistant mutant grown in (B). 
septae, multiple nucleoids, polar septum, dividing and non-dividing cells. Hence the total RNA isolated from this mixture of different types of cells is quite likely to contain specific mRNAs but in different proportions, giving wide variations in the quantitative RT-PCR data. We found the fractionation of these different subpopulations difficult.

\section{Discussion}

\section{Bacteria metamorphose into multi-septated and/or multi-nucleated phenotypes}

under diverse stress conditions. In response to diverse stress conditions, bacteria of diverse genera, including mycobacteria, have been found to stop division, grow to become multi-septated and/or multi-nucleated, and regrow back with a spurt in cfu to establish mutant population. For example, carbon starvation of $M$. smegmatis, Mycobacterium fortuitum, and Mycobacterium peregrinum under saline conditions triggered the formation of small resting cell (SMRC) morphotype, which developed into multi-septated, multi-nucleated cells that divided to generate mononucleated SMRCs (Wu et al., 2016). Similarly, starved large resting cells (LARCs) also metamorphosed into multi-septated, multi-nucleated cells. In another study, although both the $M$. tuberculosis clinical strains, TB 282 and TB 284 of smooth and rough morphology, respectively, showed loss of viability upon recovery from exposure to ambient air drying, TB 284 showed a sudden spurt in cfu from 60 to 90 min during the recovery of the sample (Klein \& Yang, 2014). It was not clear whether the TB 284 cells, which showed spurt in cfu, were multi-septated and/or multi-nucleated. However, one might infer that a sudden spurt in cell number could have most probably come from multiseptated and/or multi-nucleated cells.

Another example of external stress condition influencing ploidy levels is that of the cyanobacterial model strain, Synechocystis sp. PCC 6803. These cells show the 
ploidy levels of 53 copies and 35 copies at lower light intensity and at higher phosphate concentrations, respectively (Zerulla et al., 2016). Complete absence of phosphate induced a rapid reduction in the genome copy number, indicating that DNA replication ceased, and genomes were distributed to the daughter cells. However, prolonged incubation of the stationary phase cultures in the absence of phosphate led to the formation of monoploid cells. Similarly, the haloarchaeal species, Halobacterium salinarum, Haloferax mediterranei, and Haloferax volcanii, are all polyploid, with most of them having a higher copy number during the exponential growth phase than in the stationary phase (reviewed in Zerulla \& Soppa, 2014). The advantages of polyploidy were suggested to be low mutation rate, high resistance to x-ray and desiccation. $H$. volcanii was found to use genomic DNA both as the genetic material and as a storage for phosphate in polymeric form. Thus, under phosphate starvation, $H$. volcanii significantly decreases ploidy, thereby enabling cell multiplication, but reducing the genetic advantages of polyploidy. However, it is not known whether the polyploidy cells were multi-septated.

\section{Phenotypic plasticity as a strategy for survival under stress conditions.} Increasing number of studies have shown that morphological plasticity involving formation of multi-nucleated, multi-septated filamentation by bacterial cells under stress conditions might be a common strategy for survival (reviewed in Justice et al., 2008). Stress conditions such as high pressure (Zobell \& Cobet, 1964), nutrient depletion (Pine \& Boone, 1967), DNA damage from SOS response (Radman, 1975; Bos et al., 2012), host innate immune reactions (Justice et al., 2006), and reduced water content (Stackhouse et al., 2012) have also been found to induce multinucleated and/or multi-septated filamentation on bacterial cells. An earlier study on 
1.1 OD600 nm Mtb cells using scanning electron microscopy (SEM) showed the presence of cells with multiple ridges (Dahl, 2004). It was suggested that the cells with multiple ridges might be having multiple septae just below the ridges, indicative of the presence of multi-compartments carrying multi-nucleoid cells. It is possible that the cells might have been approaching stationary phase as the phenomenon was observed in a $1.1 \mathrm{OD}_{600 \mathrm{~nm}}$ Mtb cells. A decade later, atomic force microscopy (AFM) of Msm cells undergoing division demonstrated that the septum position would have the morphological mark of ridge-with-trough-on-both-sides type of undulating surface corresponding to the future site of cell division (Eskandarian et al., 2017).

Sudden spurt in cfu of mycobacterial systems. The response of triggering an increase in cfu against antibiotics has been noted in mycobacteria as well. For instance, upon treatment of $M$. tuberculosis $\mathrm{H}_{37} \mathrm{R}_{v}$ infected nude mice with rifampin and $\mathrm{INH}$, the cfu per lung showed an initial sudden fall from $\sim 10^{8}$ to $\sim 10^{5}$ at 2 months post-treatment. But, surprisingly, the bacillary load sharply increased to $10^{6} \mathrm{cfu}$ per lung on the $3^{\text {rd }}$ month and to $10^{8} \mathrm{cfu}$ per lung on the $4^{\text {th }}$ month, with a subsequent plateau (Zhang et al., 2011). It was of interest to note that the bacilli recovered from the increased cfu were INH-resistant. However, it was not mentioned whether the cells that underwent spurt in the cfu were multi-septated or multi-nucleated. As could be seen from our data, since all the stressed and mutated cells in the population would not undergo spurt in division, it is difficult to categorically state whether the $10^{8} \mathrm{cfu}$ per lung on the $4^{\text {th }}$ month (which arose from $10^{5} \mathrm{cfu}$ per lung on the $2^{\text {nd }}$ month) included cells that divided in spurt. Nevertheless, the response and the behaviour thereof of $M$. tuberculosis against antibiotics in mice lung and in in vitro culture are comparable in terms of the sudden increase in the cfu. This in turn validates the present in vitro study 
indicating that the response of the bacilli with a sudden spurt in cell division is an inherent trait of the bacilli irrespective of their growth habitat and pathogenic/nonpathogenic status.

\section{SOS response leading to mutagenesis as a strategy to regrow under stress}

conditions. Bacteria generate SOS response against many stress agents, including antibiotics, leading to the generation of genome-wide mutations confer mutations which in turn becomes a strategy against succumbing to lethality inflicted by the stress agents (Ryan, 1959; Radman, 1975; Witkin, 1976; Hude et al., 1990; Kato et al., 1994; McKenzie et al., 2000; McKenzie et al., 2001; Miller et al., 2004; Asad et al., 2004; Janion, 2008; Peng et al., 2011; Rodrı'guez-Beltran et al., 2012; Kreuzer, 2013; Baharoglu et al., 2014; Qin et al., 2015; Handel et al., 2015; Dapa et al., 2017; Sebastian et al., 2017; Rodríguez-Rosado et al., 2018; Chistyakov et al., 2018; Crane et al., 2018; Hoeksema et al., 2018; Geisinger et al., 2019; Swaminath, 2017). When a multi-septated, multi-nucleated filamentous bacterial cell acquires SOS-driven mutations, which can confer resistance to the stress agent, it can initiate synchronous division along the entire length of the filament, generating large numbers of viable, normal-sized, sister-daughter cells, as reported (Stackhouse et al., 2012). Therefore, if the SOS-driven mutation happens to be in the antibiotic target gene, then that mutant would get selected when confronted with the antibiotic.

In a study on the response of $E$. coli to subminimal inhibitory concentrations of ciprofloxacin, the exposure converted rod-shaped bacteria into multi-nucleated filamentous phenotype (Bos et al., 2015). Upon continuous maintenance of ciprofloxacin at low levels, the filamented cells began to divide asymmetrically and repeatedly from the filament tips, generating budded ciprofloxacin-resistant progeny 
cells. The mutant chromosomes were produced due to the mutagenic SOS response and probable recombination of the new alleles between chromosomes, which in turn might have conferred improved survival advantage. The successful segregation of multiple mutant chromosomes toward the filaments' tips was found to favour the birth of antibiotic-resistant cells. The authors proposed that the multi-nucleated filamentation was a precursor to the generation of highly resistant bacteria since it provided a strategy for the generation of mutant chromosomes that may confer survival advantages, as proposed (Bos et al., 2015). In the light of the conclusions made in this study on the antibiotic-exposed $E$. coli, the multi-septated and multinucleated phenotype and acquiring of mutations by the persistence phase population of the Msm cells exposed to rifampin for prolonged duration in our study indicate that the morphological and genetic changes might be to ensure the survival of the rifampinexposed cells.

\section{Multi-nucleation/septation, mutagenesis and spurt in cell division in antibiotic-}

stressed mycobacteria. In the background of all these observations, our present study on the rifampin/moxifloxacin-exposed Msm persister and regrowth cells and the earlier study on the rifampin/moxifloxacin-exposed Mtb persister and regrowth cells (Sebastian et al., 2017) showcase the phenomenon of sudden spurt in cell division shown by the antibiotic-resistant mutant cells emerging from the antibiotic persister population in the context of the phenomenon of antibiotic persistence. The data from fluorescence microscopy, AFM, TEM and live-cell imaging of the cell samples from 90 $\mathrm{hr}$ to $96 \mathrm{hr}$ confirmed that regrowth phase cells possessed multiple septae with multiple nucleoids. These multi-nucleated, multi-septated elongated mother cells underwent multiple constrictions to give rise to multiple sister-daughter cells. This, in turn, could 
explain the observed sudden increase in the cfu of the cells from the regrowth phase to unexpected levels. Live-cell imaging, which showed multiple constrictions of multinucleated, multi-septated cells into mononucleated individual sister-daughter cells having lengths comparable to those of individual nondividing MLP cells, supported that the reduction in cell-length, from the elongated phenotype of the $96 \mathrm{hr}$ cells to shorter size cells of the $102 \mathrm{hr}$, was due to multiple divisions of the parent cells.

Since large number of cells regrowing from the rifampin persister cells were found to be multi-nucleated, it is important to rule out the possibility of the multinucleated cells being cells with fragmented nucleoids. Had he multiple nucleoids been fragmented pieces of nucleoids, then such fragmented nucleoids: (i) would not have shown nucleoids with clear boundaries, (ii) would be of different shapes and sizes unlike a perfect same-sized round shape, and (iii) would have been found dispersed or diffused throughout the cell but would not be in an arranged manner. Apart from the absence of all these characteristics of fragmented nucleoids, the very clear sharp bands of the genomic DNA obtained from the regrowing cells of $96 \mathrm{hr}$ (see Fig. S4) showed that the genomic DNA of the cells regrowing from the rifampin persister population were not degraded.

In addition to the multi-nucleated cells, negligible proportion of the cells in the regrowing population showed anucleated portion due to polar septation. Anucleated cells had been found in ParD mutant strains of E. coli (Hussain et al., 1987) and spo0J mutants of Bacillus subtilis (Ireton et al., 1994). Overproduction of ParA in mycobacteria also generated elongated cells with multiple nucleoids without septum, and cells with asymmetric septum with nucleoids in both sister-daughter cells, indicating defects in cell division (Maloney et al., 2009). But the overproduction of ParB resulted in the formation of anucleated cells with asymmetric septum, with nucleoid in 
one of the sister-daughter cells only (Maloney et al., 2009). It was possible that specific gene systems might be getting activated or repressed when the persister cells gained mutations and began to regrow. However, the persister cells generated elevated levels of hydroxyl radical, which is a sequence-non-specific mutagen (Sakai et al., 2006). Therefore, it was possible that the persister cells might have suffered genome-wide mutations, as we had shown in the rifampicin-exposed Mtb persister cells (Sebastian et al., 2017). In such a scenario, there would be every possibility for the mutations occurring on several genes, including Par genes, involved in chromosome partitioning. Such mutations in turn might have been the reason behind the formation of negligibly low proportions of anucleated cells with polar septum, multi-nucleated cells with only very few septae and so on, generating heterogeneity.

\section{Are there differences between the cells regrowing from the} rifampicin/moxifloxacin persisters and isoniazid persisters? In the background of our study on the physiological mechanisms that drive the generation of rifampin/moxifloxacin-resistant mutants from the respective persister population, it is important to compare it with an interesting study on the behaviour of $M$. smegmatis persister cells against isoniazid. The M. smegmatis persister cells against isoniazid were found to be in a dynamic state of balance between the number of cells that undergo division and cell death such that the net cfu would not change in the presence of isoniazid (Wakamoto et al., 2013). However, it would not be possible for non-tolerant or non-resister cells to proliferate in the presence of an antibiotic. Therefore, it could be inferred from the study on the response of Msm persister cells to isoniazid that most probably the dynamically growing and dividing Msm persister cells in the presence of isoniazid would have already gained either phenotypic or genotypic 
tolerance/resistance to isoniazid. Thus, compared to the behaviour of the Msm isoniazid persister cells in the presence of isoniazid, the behaviour of the rifampin and moxifloxacin persister cells of Mtb and Msm in the present study were very different.

Broad implications of the present study. The fact that this behaviour was found in both the pathogenic Mtb and the saprophytic Msm cells upon prolonged exposure to two antibiotics of totally diverse mode of action, rifampin and moxifloxacin, confirmed the phenomenon to be a natural one that is neither specific to antibiotics nor to any specific mycobacterial species. This phenomenon of the formation of multi-septated polyploidy mycobacterial cells seems to be a unique mode of generation of the genetically resistant mutants against antibiotics, when they are freshly emerging from the antibiotic persister population. Further, since even Escherichia coli also showed similar response against subminimal inhibitory concentrations of ciprofloxacin (Bos et al., 2015), these findings have a broad significance as a general strategy adopted by diverse bacterial genera to emerge as drug-resistant strains against antibiotics.

Thus, many bacteria, including mycobacteria, use the strategy of sudden spurt in cell division, after gaining resistance against diverse stress conditions, either by generating multi-septated and/or polyploidy cells. However, whether the mycobacterial persister cells, formed in response to exposure to microbicidal concentrations of antibiotics, would respond in a similar manner through the formation of multi-septated and multi-nucleated cells undergoing spurt in the generation of antibiotic-resistant genetically mutant progeny cells remained unknown till the present study. Since we had observed the phenomenon in Mtb cells also, possession of such a trait by the tubercle bacilli in the patients can pose a major impediment in TB treatment for the eradication of drug resistance developed by the pathogen. 


\section{Materials and methods}

Bacterial strain and culture conditions. Mycobacterium smegmatis $\mathrm{mc}^{2} 155$ (Snapper et al., 1990; Msm) was grown in autoclaved sterilised fresh Middlebrook 7H9 liquid cultures containing $0.2 \%$ glycerol (Fisher Scientific) and $0.05 \%$ Tween 80 (Sigma) under continuous gyration at $170 \mathrm{rpm}, 37^{\circ} \mathrm{C}$ by taking $5: 1$ head space to volume ratio. Plating experiments were performed on Mycobacteria $7 \mathrm{H} 11$ agar plates (Difco) with and/or without rifampin (125 $\mu \mathrm{g} / \mathrm{ml}$; MP Biomedicals) at $37^{\circ} \mathrm{C}$ for 3 to 4 days. Msm cultures were also grown in the presence of moxifloxacin (Cayman Chemicals) at $0.5 \mu \mathrm{g} / \mathrm{ml}(3.759 \times \mathrm{MBC})$, prepared from the stock of $2 \mathrm{mg} / \mathrm{ml}$ solution in DMSO. All the experiments were conducted using actively growing mid-log phase cells with an approximate cell density of $10^{6}$ cells $/ \mathrm{ml}$.

Growth curve experiments. From the starting of the experiment, liquid cultures were exposed to $25 \mu \mathrm{g} / \mathrm{ml}$ concentration of the antibiotic rifampin (MP Biomedicals). The antibiotic stock solution $(50 \mathrm{mg} / \mathrm{ml})$ was made by dissolving rifampin powder (MP Biomedicals) in DMSO (Merck Millipore) and filter sterilised using 0.22 $\mu \mathrm{m}$ PVDF syringe filters (Millex-GV). Dilutions of the antibiotic (rifampin) was performed using $0.22 \mu \mathrm{m}$ PVDF (Millex-GV) filter sterilised DMSO (Merck Millipore). Similarly, moxifloxacin $(0.5 \mu \mathrm{g} / \mathrm{ml} ; 3.759 x \mathrm{MBC})$ was added to an independent $100 \mathrm{ml} \mathrm{Msm}$ secondary culture. Post-antibiotic exposure, cells were taken at every $6 \mathrm{hr}$ time interval and plated on antibiotic free and antibiotic containing $(125 \mu \mathrm{g} / \mathrm{ml})$ Mycobacteria $7 \mathrm{H} 11$ agar (Difco) plates to check the actual number of colony forming unit (cfu) present at that particular time point and their respective resisters. Dilution of the cultures for the plating was performed using fresh Middlebrook 7H9 media. Plates were incubated in Innova 4200 Incubator Shaker at $37^{\circ} \mathrm{C}$ for $3-5$ days. 
Fold increase in the cfu calculations. Fold increase in cfu at any specific time point was calculated by normalising the cfu value of that specific time point with the cfu obtained at its previous time point.

Hoechst staining of nucleoid. $200 \mu \mathrm{l}$ of the cells from the mid-log as well as from regrowth phases were taken into an Eppendorf tube and pelleted down at $~ 5000 \times \mathrm{g}$ for $10 \mathrm{~min}$ at room temperature. The supernatant was removed, and the cell pellet was washed once with fresh Middlebrook 7H9 (Difco) media and pelleted again with same centrifugation conditions. The cell pellet was resuspended in $200 \mu \mathrm{l}$ of fresh Middlebrook 7H9 (Difco) media and $10 \mathrm{ng} / \mathrm{ml}$ concentration of the Hoechst 33342 stain (Sigma) was added. This mixture was incubated at $37^{\circ} \mathrm{C}$ (Innova 4200 Incubator Shaker) for $10 \mathrm{~min}$ in dark. After $10 \mathrm{~min}$, the cells were washed to remove the excess dye by pelleting down at $\sim 5000 \mathrm{xg}$ for $10 \mathrm{~min}$ at room temperature and the pellet was resuspended in fresh Middlebrook 7H9 (Difco) media and a drop of the cell suspension was taken on a clean glass slide and dispersed evenly. The slide was air dried at room temperature for 10 min in dark and a small drop of glycerol was added and covered with coverslip. The slide thus made was observed under Carl Zeiss AXIO Imager MI microscope at $100 x$ by putting a drop of immersion oil on top of the coverslip.

Sample preparation for Atomic Force Microscopy. Sample preparation for atomic force microscopy was carried out as described (Bolshakova et al., 2001) with minor modifications. In brief, $1 \mathrm{ml}$ of the cells from regrowth phase (96 hr) were taken in a fresh Eppendorf tube and harvested by centrifuging them at $\sim 5000 \times \mathrm{g}$ for $10 \mathrm{~min}$ at room temperature. The cell pellet was washed once with fresh Middlebrook 7H9 liquid media and parallelly a glass coverslip was cleaned once with acetone (Merck 
Millipore), and once it dried, a drop of the cell suspension was added on the coverslip. The cover slip was air dried for $10 \mathrm{~min}$ at room temperature and post air dry, it was washed gently with fresh de-ionised water and again set for drying for 10 min at room temperature. The cells fixed on the glass coverslip were observed under Atomic Force Microscope in contact independent mode of scanning.

Sample preparation for Transmission Electron Microscopy. Cells from regrowth phase (96 hr) were taken and processed for transmission electron microscopic analysis as described (Takade et al., 1983; Vijay et al., 2012) with minor modifications. In brief, $1 \mathrm{ml}$ of the cells from regrowth phase (96 hr) were taken into Eppendorf tube and harvested by centrifuging them at $\sim 5000 \times \mathrm{g}$ for $10 \mathrm{~min}$ at room temperature. Supernatant was discarded and the cell pellet was resuspended in $0.15 \mathrm{M}$ sodium cacodylate- $\mathrm{HCl}$ buffer $\mathrm{pH} 7.4$, containing $1 \%$ osmium tetroxide $\left(\mathrm{OsO}_{4}\right)(\mathrm{w} / \mathrm{v})(\mathrm{Sigma})$ and incubated (Innova 4200 Incubator Shaker) for $1 \mathrm{hr}$ at room temperature in dark. After $1 \mathrm{hr}$, cells were washed with the same buffer by pelleting them at $\sim 5000 \times \mathrm{g}$ for $10 \mathrm{~min}$ at room temperature. The cell pellet was resuspended in $0.15 \mathrm{M}$ sodium cacodylate (w/v) (Sigma)- $\mathrm{HCl}$ buffer $\mathrm{pH} 7.4$ containing $2 \%$ glutaraldehyde (v/v) (Sigma), 2\% tannic acid (w/v) and incubated at room temperature for 2 hrs in dark. The cell suspension was washed with the same buffer for 10 min at room temperature at $\sim 5000 \times \mathrm{g}$ and the pellet was resuspended in $0.15 \mathrm{M}$ sodium cacodylate buffer containing $1 \%$ OsO4 and incubated overnight at $4^{\circ} \mathrm{C}$. Post overnight incubation, the cell suspension was washed with the same buffer at $\sim 5000 \times \mathrm{g}$ for $10 \mathrm{~min}$ at room temperature and the pellet was subjected for dehydration with serial dilutions of ethanol (Merck Millipore) (20\%, 30\%, 50\%, 70\%, 90\%, 100\%, and 100\%). After dehydration, the cell pellet was resuspended in 50\% LR White resin (1:1 volume of LR 
White resin (London Resin Company) and 95\% ethanol (Merck Millipore)) and the cell suspension was stored in $4^{\circ} \mathrm{C}$ till further use. Gelatine blocks were prepared by spinning down this cell suspension at room temperature for $10 \mathrm{~min}$ at $\sim 5000 \mathrm{xg}$ and an aliquot of the cell pellet was taken and made it to adhere at the bottom of the gelatine capsule (Electron Microscopy Sciences) and then capsule was filled with $100 \%$ LR White resin. This gelatine capsule was kept at $60^{\circ} \mathrm{C}$ for $48-56 \mathrm{hrs}$ till it became rock hard. Finally, the blocks were trimmed and cut into $70 \mathrm{~nm}$ ultra-thin sections using ultra microtome (Power Tome XI). These sections were collected on a copper grid (150 mesh x $165 \mu$ m pitch; Sigma-Aldrich) and the copper grids containing sections were subjected for uranyl acetate and led citrate staining. The stained sections were observed at $120 \mathrm{kV}$ under Transmission Electron Microscopy (Tecnai Bio-TWIN).

Cell length measurements and size distribution graph. DIC images of cell before (0 hr) and post antibiotic exposure (till $120 \mathrm{hr}$ ) were captured using Carl Zeiss AXIO Imager M1 microscope and measured using AxioVision 4 software.

Glycerol estimation. Free glycerol concentration in the culture supernatant was measured by converting glycerol to formaldehyde using periodate (White et al., 1974) and spectrophotometric estimation of formaldehyde by means of Hantzsch reaction at $410 \mathrm{~nm}$ (Nash 1953; Bondioli and Bella, 2005). Glycerol concentration in the supernatant was measured at different time points, as described (Bondioli and Bella, 2005), with minor modifications. In brief, the reagents were prepared as follows. (i). acetic acid stock solution: 1.6 $\mathrm{M}$ aqueous solution in autoclaved distilled water; (ii). ammonium acetate stock solution: 4.0 $\mathrm{M}$ aqueous solution in autoclaved distilled 
water; (iii). $0.2 \mathrm{M}$ acetyl acetone solution: $200 \mu \mathrm{l}$ of acetyl acetone was added into 5 $\mathrm{ml}$ of acetic acid stock solution, mixed well, and $5 \mathrm{ml}$ of ammonium acetate stock solution was added; (iv). $10 \mathrm{mM}$ sodium (meta) periodate solution: $21 \mathrm{mg}$ of sodium (meta) periodate was dissolved in $5 \mathrm{ml}$ of acetic acid stock solution, and once sodium (meta) periodate was completely dissolved, $5 \mathrm{ml}$ of ammonium acetate stock solution was added. Working solvent: equal volumes of autoclaved distilled water and $95 \%$ ethanol.

Different concentrations of glycerol standards were prepared as $0.4,0.2,0.1$, $0.05,0.025,0.0125$, and $0.00625 \%$ by serial dilution using distilled water. $13 \mu \mathrm{l}$ of glycerol standard was dissolved in $117 \mu \mathrm{l}$ of distilled water. $390 \mu \mathrm{l}$ of working solvent was added to $130 \mu \mathrm{l}$ of the diluted standard. Three hundred and twelve (312) $\mu \mathrm{l}$ of sodium (meta) periodate solution was added and mixed on a vortex mixer for $30 \mathrm{sec}$. Subsequently, $312 \mu \mathrm{l}$ of $0.2 \mathrm{M}$ acetyl acetone solution was added and kept in a heating block at $70^{\circ} \mathrm{C}$ for $1 \mathrm{~min}$. The sample was then immediately cooled by keeping the tube in ice. Absorbance was measured immediately at $410 \mathrm{~nm}$ in a UV-Visible spectrophotometer. Standard calibration curve was constructed and equation for the straight line, i.e. $y=m x+c$, was used to determine the glycerol concentration in the culture medium, where $\mathrm{y}$ is absorbance at $410 \mathrm{~nm}, \mathrm{~m}$ is the slope, $\mathrm{c}$ is the $\mathrm{y}$ intercept, and $x$ is the unknown concentration of glycerol to be determined as $x=(y-c) \div m$.

The glycerol concentration in the culture supernatants of the antibiotic exposed culture was determined. In brief, culture supernatants at different time points were collected by centrifuging $1 \mathrm{ml}$ of $\mathrm{Msm}$ culture at $\sim 5,000 \times \mathrm{g}$ for $10 \mathrm{~min}$ at room temperature, from independently grown biological triplicate cultures. Samples were treated with sodium (meta) periodate and acetyl acetone solution in the same way as in the case of the standard. Absorbance was measured at $410 \mathrm{~nm}$ and the glycerol 
concentration $(x)$ was calculated with the equation of the straight line of the standard calibration curve.

\section{Patch plating of cells from rifampin-free plate to rifampin-containing plate. $\mathrm{A}$} small portion of the colony from antibiotic free plate was picked up with the help of toothpick and seeded on antibiotic (125 $\mu \mathrm{g} / \mathrm{ml}$ rifampin; MP Biomedicals) containing plate. This plate was incubated at $37^{\circ} \mathrm{C}$ (Innova 4200 Incubator Shaker) bacterial incubator for 3-5 days.

Expected and observed cfu. Fold change of cfu at any specific time point was calculated by considering the next time point cfu value as ' $\mathrm{B}$ ' and subtracted this value with earlier time point cfu value (considered as ' $A$ ') and the resulting value was divided with the time point ' $A$ '. Expected cfu increase within 6 hrs will be 4 times the number of cells present at the previous time point. Thus, any time point where the cells showed more than 4-fold increase in cfu, was considered an unusual division. The table was made accordingly with the observed and expected cfu values. The time points where the cell number was higher than the expected cfu were highlighted in box.

Live cell time-lapse microscopy. Live cell time-lapse microscopy of Msm regrowth phase cells was performed using agarose pad method, as described (Jong et al., 2011; Joyce et al., 2011; Vijay et al., 2014a, b) with minor modifications. Agarose pad was prepared by using spent media of $90 \mathrm{hr}$ rifampin $(25 \mu \mathrm{g} / \mathrm{ml})$ exposed culture and $1.75 \%$ low melting point agarose on a clean glass slide. After solidification, a portion of the agarose (about $1 / 5^{\text {th }}$ of the total agarose pad area) was cut out using a blade to make a well for the introduction of rifampin into the agarose pad. Towards one side of 
the well, a tip was attached which was connected to a syringe for removal of rifampin containing medium. $10 \mu \mathrm{l}$ of $90 \mathrm{hr}$ rifampin $(25 \mu \mathrm{g} / \mathrm{ml})$ exposed Msm cells were placed on top of the agarose pad and spread evenly by tilting the slide. The slide was covered by a cover slip at $45^{\circ}$ angle from the base glass slide, leaving a portion of the well open for the introduction of rifampin with a syringe. The agarose pad with the cells was kept at $37^{\circ} \mathrm{C}$ for $1 \mathrm{hr}$ incubation to facilitate cell adhesion. This slide was observed under Carl Zeiss AxioVision 4 microscope using live cell imaging option, at 100x magnification (DIC), with $0.2 \mu \mathrm{m}$ slice distance Z-stacking at $37^{\circ} \mathrm{C}$. Individual cells were observed and the DIC images were taken at every 10 min time interval. The data was analysed and the parameters like cell length and cell constriction were determined on the images, using AxioVision 4 and ImageJ software.

Cell pellet preparation for genomic DNA. Colonies taken from antibiotic free or antibiotic containing plates were resuspended in sterilised fresh Middlebrook $7 \mathrm{H} 9$ (Difco) liquid media and subjected for pipetting at least 10-15 times to remove the clumps. The cell suspension was re-inoculated into fresh sterilised Middlebrook 7H9 (Difco) liquid medium with and/or without antibiotic (25 $\mu \mathrm{g} / \mathrm{ml}$ rifampin; MP Biomedicals) and incubated at $37^{\circ} \mathrm{C}$ (Innova 4200 Incubator Shaker) with a gyration speed of $170 \mathrm{rpm}$ till the culture reaches an approximate cell density of $10^{6}$ cells $/ \mathrm{ml}$. Cultures $(50 \mathrm{ml})$ were taken into Sorvall tube and harvested at $\sim 5400 \times \mathrm{g}$ at room temperature. Supernatant was discarded and the cell pellet was subjected for genomic DNA isolation.

Genomic DNA isolation. Genomic DNA was prepared from mid-log phase as well as from rifampin-exposed cell cultures by phenol-chloroform extraction method. In brief, 
cell pellet was lysed by resuspending in $1 \mathrm{ml}$ of Tris- $\mathrm{HCl}$-EDA buffer $(10 \mathrm{mM}$ Tris- $\mathrm{HCl}$ containing $1 \mathrm{mM}$ EDTA, pH 8) containing $3 \mathrm{mg} / \mathrm{ml}$ lysozyme (Chicken egg white; Fluka) and $1 \mathrm{mg} / \mathrm{ml}$ lipase (from Candida cylindracea; Sigma) in an Eppendorf tube. This cell suspension was kept at $37^{\circ} \mathrm{C}$ water bath for $4 \mathrm{hrs}$ with intermittent mixing by inverting the Eppendorf tubes. The cell lysis was carried out by adding $2 \%$ SDS

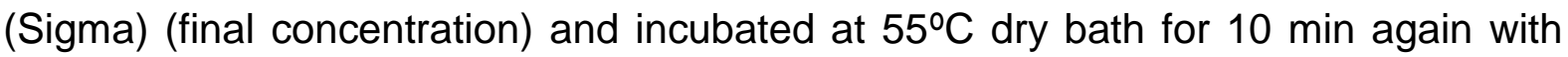
intermittent mixing (once in $30 \mathrm{~min}$ ) by inverting the Eppendorf tubes. The cell lysate was centrifuged at $\sim 7800 \times \mathrm{g}$ for $10 \mathrm{~min}$ at $4^{\circ} \mathrm{C}$. The supernatant $(\sim 800 \mu \mathrm{l})$ was collected using cut tips and subjected for phenol-chloroform extraction using equal volumes of ice-chilled phenol (Tris- $\mathrm{HCl}$ saturated $\mathrm{pH}$ 7.8; Sisco Research Laboratories) chloroform (Nice Chemicals) mixture in 1:1 ratio (volume to volume). The suspension was mixed by inverting the Eppendorf tube $\sim 5$ to 10 times and centrifuged at $\sim 7800 \times \mathrm{g}$ for $10 \mathrm{~min}$ at $4^{\circ} \mathrm{C}$. The supernatant was collected and mixed with equal volume of phenol (Tris- $\mathrm{HCl}$ saturated; $\mathrm{pH} 7.8$ ) and again mixed by inverting the Eppendorf tube $\sim 5$ to 10 times. This suspension was centrifuged at $\sim 7800 \times \mathrm{g}$ for $10 \min$ at $4^{\circ} \mathrm{C}$. To this supernatant, equal volumes of ice chilled chloroform (Nice Chemicals) was added and mixed again by inverting the tubes for 5 to 10 times. This mixture was again subjected for centrifugation at $\sim 5000 \times \mathrm{g}$ for $10 \mathrm{~min}$ at $4^{\circ} \mathrm{C}$ and the supernatant was collected. To this supernatant, $1 / 10^{\text {th }}$ volume of $0.3 \mathrm{M}$ sodium acetate ( $\mathrm{pH} 7.4$; Sigma) (final concentration) was added and mixed well with pipette. After this, 2.5 volumes of $95 \%$ ice-cold ethanol (Merck Millipore) was added and mixed vigorously for 15 to 20 times by inverting the Eppendorf tubes. The suspension was kept at $4^{\circ} \mathrm{C}$ overnight for better precipitation. After overnight incubation at $4^{\circ} \mathrm{C}$, DNA was pelleted down by centrifuging the suspension at $\sim 11300 \times \mathrm{g}$ for 20 min at $4^{\circ} \mathrm{C}$. Supernatant was discarded and the cell pellet was washed once with $70 \%$ ethanol 
(Merck Millipore) and the pellet was air dried for $10 \mathrm{~min}$. After $10 \mathrm{~min}$, the obtained DNA pellet was dissolved in 1x Tris-HCl-EDTA buffer (10 mM Tris-HCl, 1mM EDTA, $\mathrm{pH}$ 8). This DNA was subjected for RNase A treatment by incubating with $1 \mu \mathrm{l}$ of 10 $\mathrm{mg} / \mathrm{ml}$ RNase A (bovine pancreatic RNase; Sigma) at $50^{\circ} \mathrm{C}$ for $60 \mathrm{~min}$. After RNase treatment, DNA was re-extracted by phenol-chloroform method and precipitated as mentioned earlier. Finally, the obtained gDNA was dissolved in $1 \mathrm{x}$ Tris-HCl-EDTA buffer (10 mM Tris- $\mathrm{HCl}, 1 \mathrm{mM}$ EDTA, $\mathrm{pH} 8$ ) and stored at $4^{\circ} \mathrm{C}$ till further use.

PCR amplification of RRDR region. RRDR locus was PCR amplified using RRDR specific forward, and reverse primers (Table. 4) using Phusion Polymerase (Thermo Scientific, USA). The PCR amplified products were run on $1.5 \%$ agarose gel and the specific amplified band was eluted using gel elution kit (GeneJET Gel Extraction Kit; Thermo Scientific, USA). Sequence determination was performed for both the strands of the DNA by Chromous Biotech, Bangalore, India.

HPF staining of $\boldsymbol{M}$. smegmatis cells. HPF staining of cells post antibiotic exposure (25 $\mu \mathrm{g} / \mathrm{ml}$ rifampin; Sigma) was carried out by taking $500 \mu \mathrm{l}$ of the culture from respective time points into Eppendorf tubes and incubated them with $5 \mu \mathrm{M} 3$ '-(phydroxyphenyl fluorescein (HPF; Invitrogen) (0.5 $\mu \mathrm{l}$ of HPF from $5 \mathrm{mM}$ stock) (Setsukinai et al., 2003 and Mukherjee et al., 2009) at $37^{\circ} \mathrm{C}$ for $15 \mathrm{~min}$ with shaking at 170 rpm in a bacteriological incubator shaker (Innova 4200 Incubator Shaker) in dark. The cells, post incubation with HPF, were centrifuged at $~ 5000 \times \mathrm{g}$ for $10 \mathrm{~min}$ at room temperature, resuspended in $200 \mu$ of fresh Middlebrook $7 \mathrm{H} 9$ (Difco) and the cell suspension was taken into a clear bottom black multi-well Polystyrene assay plate. Fluorescence was observed using Tecan Infinite® 200 PRO series plate reader at the 
excitation maxima of $490 \mathrm{~nm}$ and emission maxima of $520 \mathrm{~nm}$. The fluorescence obtained by multi-plate reader was divided with the cfu value obtained by plating to get the fluorescence value per cell. The obtained value was normalised with the value from the $48 \mathrm{hr}$ time point and the fold increase in the fluorescence per cell was plotted in the graph against time.

\section{References}

1. Hobby, G. L., Meyer, K. \& Chaffee, E. Observations on the Mechanism of Action of Penicillin. Exptl Biol Med. 50, 281-285 (1942). https://doi.org/10.3181/00379727-50-13773

2. Bigger, J. W. Treatment of Staphylococcal infections with penicillin by intermittent sterilisation. Lancet 244, 497-500 (1944). https://doi.org/10.1016/S0140-6736(00)74210-3

3. Robertson, H. E. The persistence of tuberculous infections. Am J Pathol 9, 711$718(1933)$

4. McCune, R. M., Feldmann, F. M., Lambert, H. P. \& McDermott, W. Microbial persistence. I. The capacity of tubercle bacilli to survive sterilisation in mouse tissues. $\quad \mathrm{J} \quad$ Exp $\quad$ Med 123, 445-468 (1966a). https://doi.org/10.1084/jem.123.3.445

5. McCune, R. M., Feldmann, F. M. \& McDermott, W. Microbial persistence. II. Characteristics of the sterile state of tubercle bacilli. J Exp Med 123, 469-486 (1966b). https://doi.org/10.1084/jem.123.3.469

6. Hu, Y., Mangan, J. A., Dhillon, J., Sole, K. M., Mitchison, D. A., Butcher, P. D. \& Coates, A. R. Detection of mRNA transcripts and active transcription in persistent Mycobacterium tuberculosis induced by exposure to rifampin or 
$\begin{array}{lllll}\text { pyrazinamide. } & \text { J }\end{array}$ https://doi.org/10.1128/JB.182.22.6358-6365.2000

7. Lenaerts, A. J. et al. Location of persisting mycobacteria in a guinea pig model of tuberculosis revealed by r207910. Antimicrob Agents Chemother 51, 33383345 (2007). https://doi.org/10.1128/AAC.00276-07

8. Hoff, D. R. et al. Location of intra- and extracellular Mycobacterium tuberculosis populations in lungs of mice and guinea pigs during disease progression and after drug treatment. PLoS One 6, e17550 (2011). https://doi.org/10.1371/journal.pone.0017550

9. Sebastian, J. et al. De Novo Emergence of Genetically Resistant Mutants of Mycobacterium tuberculosis from the Persistence Phase Cells Formed against Antituberculosis Drugs In Vitro. Antimicrob Agents Chemother 61, e01343-16 (2017). https://doi.org/10.1128/AAC.01343-16

10. Medlar, E. M., Bernstein, S. \& Steward, D. M. A Bacteriologic Study of Resected Tuberculous Lesions. Am Rev Tuberc 66, 36-43 (1952)

11. Beck, F. \& Yegian, D. A study of the tubercle bacillus in resected pulmonary lesions. Am Rev Tuberc 66, 44-51 (1952).

12. Opie, E. L. \& Aronson, J. D. Tubercle bacilli in latent tuberculosis lesions and in lung tissue without tuberculous lesions. Arch Pathol Lab Med 4, 1-21 (1927).

13. Robertson, H. E. The persistence of tuberculous infections. Am J Pathol 9, 711718 (1933)

14. Stewart, G. R., Robertson, B. D. \& Young, D. B. Tuberculosis: A problem with $\begin{array}{lllll}\text { persistence. Nat } & \text { Rev }\end{array}$ https://doi.org/10.1038/nrmicro749 
15. Khomenko, A. G. The variability of Mycobacterium tuberculosis in patients with cavitary pulmonary tuberculosis in the course of chemotherapy. Tubercle 68, 243-253 (1987). https://doi.org/10.1016/0041-3879(87)90064-X

16. McCune, R. M. Jr. \& Tompsett, R. Fate of Mycobacterium tuberculosis in mouse tissues as determined by the microbial enumeration technique. I. The persistence of drug susceptible tubercle bacilli in the tissues despite prolonged antimicrobial therapy. J Exp Med 104, 737-762 (1956a). https://doi.org/10.1084/jem.104.5.737

17. McCune, R. M. Jr., Tompsett, R. \& McDermott, W. The fate of Mycobacterium tuberculosis in mouse tissues as determined by the microbial enumeration technique. II. The conversion of tuberculous infection to the latent state by the administration of pyrazinamide and a companion drug. J Exp Med 104, 763802 (1956). https://doi.org/10.1084/jem.104.5.763

18. McCune, R. M., Feldmann, F. M., Lambert, H. P. and McDermott, W. Microbial persistence. I. The capacity of tubercle bacilli to survive sterilization in mouse tissues. J Exp Med 123, 445-468 (1966a). https://doi.org/10.1084/jem.123.3.445.

19. McCune, R. M., Feldmann, F. M. and McDermott, W. Microbial persistence. II. Characteristics of the sterile state of tubercle bacilli. J Exp Med 123, 469-486 (1966b). https://doi.org/10.1084/jem.123.3.469.

20.Rees, R. J. \& Hart, P. D. Analysis of the host-parasite equilibrium in chronic murine tuberculosis by total and viable bacillary counts. Br J Exp Pathol 42, 8388 (1961).

21. Kashino, S. S., Napolitano, D. R., Skobe, Z. \& Campos-Neto, A. Guinea pig model of Mycobacterium tuberculosis latent/dormant infection. Microbes Infect 10, 1469-1476 (2008). https://doi.org/10.1016/j.micinf.2008.08.010 
22. McKinney, J. D. et al. Persistence of Mycobacterium tuberculosis in macrophages and mice requires the glyoxylate shunt enzyme isocitrate lyase. Nature 406, 735-738 (2000). https://doi.org/10.1038/35021074

23. Adams, K. N. et al. Drug tolerance in replicating mycobacteria mediated by a macrophage-induced efflux mechanism. Cell 145, 39-53 (2011). https://doi.org/10.1016/j.cell.2011.02.022

24.Singh, R., Barry, C. E. 3rd. \& Boshoff, H. I. The three RelE homologs of Mycobacterium tuberculosis have individual, drug-specific effects on bacterial

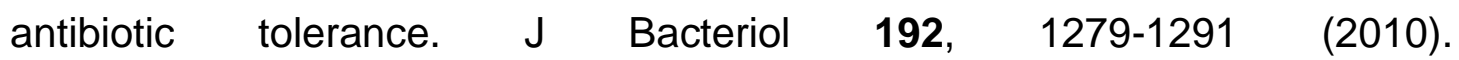
https://doi.org/10.1128/JB.01285-09

25. Keren, I., Kaldalu, N., Spoering, A., Wang, Y., \& Lewis, K. Persister cells and tolerance to antimicrobials. FEMS Microbiol Lett 230, 13-18 (2004). https://doi.org/10.1016/S0378-1097(03)00856-5

26. Mwangi, M. M. et al. Tracking the in vivo evolution of multidrug resistance in Staphylococcus aureus by whole-genome sequencing. Proc Natl Acad Sci USA 104, 9451-9456 (2007). https://doi.org/10.1073/pnas.0609839104

27.Sun, G. et al. Dynamic population changes in Mycobacterium tuberculosis during acquisition and fixation of drug resistance in patients. J Infect Dis 206, 1724-1733 (2012). https://doi.org/10.1093/infdis/jis601

28. World Health Organization. Global tuberculosis report 2015, 20th ed. World Health Organization. (2015). https://apps.who.int/iris/handle/10665/191102

29. Cohen, N. R., Lobritz, M. A. \& Collins, J. J. Microbial persistence and the road to drug resistance. Cell Host Microbe 13, 632-642 (2013). https://doi.org/10.1016/j.chom.2013.05.009 
30. Swaminath, S. Cellular and Molecular Features of the Response of Mycobacterium smegmatis to Rifampicin and Moxifloxacin upon Prolonged Exposure. Doctoral thesis, Indian Institute of Science, Bangalore, India. (2017).

31.Grant, S. S., Kaufmann, B. B., Chand, N. S., Haseley. N. \& Hung, D. T. Eradication of bacterial persisters with antibiotic-generated hydroxyl radicals. Proc Natl Acad Sci USA 109, 12147-12152 (2012). https://doi.org/10.1073/pnas.1203735109

32. Cavusoglu, C., Hilmioglu, S., Guneri, S. \& Bilgic, A. Characterisation of rpoB mutations in rifampin-resistant clinical isolates of Mycobacterium tuberculosis from Turkey by DNA sequencing and line probe assay. J Clin Microbiol 40, 4435-4438 (2002). https://doi.org/10.1128/JCM.40.12.4435-4438.2002

33. Takiff, H. E. et al. Cloning and nucleotide sequence of Mycobacterium tuberculosis gyrA and gyrB genes and detection of quinolone resistance mutations. Antimicrob Agents Chemother 38, 773-780 (1994). https://doi.org/10.1128/AAC.38.4.773Gadagkar, R. \& Gopinathan, K. P. Growth of Mycobacterium smegmatis in minimal and complete media. J. Biosci. 2, 337348 (1980). https://doi.org/10.1007/BF02716867

34.Dahl, J. L. Electron microscopy analysis of Mycobacterium tuberculosis cell division. FEMS Microbiol Lett 240, 15-20 (2004). https://doi.org/10.1016/j.femsle.2004.09.004

35. Eskandarian, H. A. et al. Division site selection linked to inherited cell surface wave troughs in mycobacteria. Nat Microbiol 2, 17094 (2017). https://doi.org/10.1038/nmicrobiol.2017.94 
36. Lin, D. C., Levin, P. A., \& Grossman, A. D. Bipolar localization of a chromosome partition protein in Bacillus subtilis. Proc Natl Acad Sci U S A. 94, 4721-4726 (1997) https://doi.org/10.10.1073/pnas.94.9.4721

37.Webb, C. D., Teleman, A., Gordon, S., Straight, A., Belmont, A., Lin, D. C., Grossman, A. D., Wright, A., \& Losick, R. Bipolar localization of the replication origin regions of chromosomes in vegetative and sporulating cells of $B$. subtilis. Cell. 88, 667-674 (1997) https://doi.org/10.10.1016/s0092-8674(00)81909-1

38. Van Helvoort, J. M., Huls, P. G., Vischer, N. O, \& Woldringh, C.L. Fused nucleoids resegregate faster than cell elongation in Escherichia coli pbpB (Ts) filaments after release from chloramphenicol inhibition. Microbiology. 144, 1309-1317 (1998) https://doi.org/10.10.1099/00221287-144-5-1309

39.Ben-Yehuda, S., Rudner, D. Z., \& Losick, R. RacA, a bacterial protein that anchors chromosomes to the cell poles. Science. 299, 532-536 (2003) https://doi.org/10.10.1126/science.1079914

40.Errington, J., Murray, H., \& Wu, L. J. Diversity and redundancy in bacterial chromosome segregation mechanisms. Philos Trans R Soc Lond B Biol Sci. 360, 497-505 (2005) https://doi.org/10.10.1098/rstb.2004.1605

41.Zhang, C., Shao, P. G., van Kan, J. A., \& van der Maarel, J. R. Macromolecular crowding induced elongation and compaction of single DNA molecules confined in a nanochannel. Proc Natl Acad Sci U S A. 106, 16651-16656. (2009) https://doi.org/10.10.1073/pnas.0904741106

42. Fisher, J. K, Bourniquel, A., Witz, G., Weiner, B., Prentiss, \& M., Kleckner, N. Four-dimensional imaging of $E$. coli nucleoid organization and dynamics in living cells. Cell. 153, $\quad$ 882-895 (2013) https://doi.org/10.10.1016/j.cell.2013.04.006 
43.Gorle, A. K., Bottomley, A. L., Harry, E. J., Collins, J. G., Keene, \& F.R., Woodward, C.E. DNA condensation in live E. coli provides evidence for transertion. $\quad$ Mol Biosyst. $\quad 13, \quad 677-680$ (2017) https://doi.org/10.10.1039/c6mb00753h

44.Sargent, M. G. Control of cell length in Bacillus subtilis. J Bacteriol. 123, 7-19 (1975)

45.Donachie, W.D., Begg, K. J, \& Vicente, M. Cell length, cell growth and cell division. Nature. 264, 328-333 (1976) https://doi.org/10.10.1038/264328a0

46.Donachie, W. D., \& Begg, K. J. Cell length, nucleoid separation, and cell division of rod-shaped and spherical cells of Escherichia coli. J Bacteriol.171, 4633-4639 (1989) https://doi.org/10.10.1128/jb.171.9.4633-4639.

47. Sharpe, M. E., Hauser, P. M., Sharpe, R. G., \& Errington, J. Bacillus subtilis cell cycle as studied by fluorescence microscopy: constancy of cell length at initiation of DNA replication and evidence for active nucleoid partitioning. $J$ Bacteriol.180, 547-555 (1998)

48. Adler, H. I., Terry, C. E., \& Hardigree, A. A. Giant cells of Escherichia coli. J Bacteriol. 95, 139-42 (1968)

49. Spratt, B. G. Distinct penicillin binding proteins involved in the division, elongation, and shape of Escherichia coli K12. Proc Natl Acad Sci USA. 72, 2999-3003 (1975) https://doi.org/10.10.1073/pnas.72.8.2999

50. Martínez-Moya, M., de Pedro, M. A, Schwarz, H., \& García-del Portillo, F. Inhibition of Salmonella intracellular proliferation by non-phagocytic eucaryotic cells. Res Microbiol. 149, 309-318 (1998) https://doi.org/10.10.1016/s09232508(98)80436-1 
51.Weiss, D.S., Chen, J. C., Ghigo, J. M., Boyd, D., \& Beckwith, J. Localization of Ftsl (PBP3) to the septal ring requires its membrane anchor, the $\mathrm{Z}$ ring, Fts $\mathrm{A}$, FtsQ, and FtsL. J Bacteriol. 181, 508-520 (1999)

52. Rosenberger, C. M., \& Finlay, B. B. Macrophages inhibit Salmonella typhimurium replication through MEK/ERK kinase and phagocyte NADPH oxidase activities. J Biol Chem. 277, 18753-18762 (2002) https://doi.org/10.10.1074/jbc.M110649200

53. Chauhan. A., Lofton, H., Maloney, E., Moore, J., Fol, M., Madiraju, M. V., \& Rajagopalan, M. Interference of Mycobacterium tuberculosis cell division by Rv2719c, a cell wall hydrolase. Mol Microbiol. 62, 132-47 (2006) https://doi.org/10.10.1111/j.1365-2958.2006.05333.x

54. Justice, S. S., Hunstad, D. A., Seed, P. C., \& Hultgren, S. J. Filamentation by Escherichia coli subverts innate defenses during urinary tract infection. Proc Natl Acad Sci USA. 103, 19884-19889 (2006) https://doi.org/10.10.1073/pnas.0606329104

55. Justice, S. S., Hunstad, D. A., Cegelski, L., \& Hultgren, S. J. Morphological plasticity as a bacterial survival strategy. Nat Rev Microbiol. 6, 162-168 (2008) https://doi.org/10.10.1038/nrmicro1820

56. Möller, J., Emge, P., Avalos Vizcarra, I., Kollmannsberger, P. \& Vogel, V. Bacterial filamentation accelerates colonization of adhesive spots embedded in biopassive surfaces. New J. Phys. 15, $125016 \quad$ (2013) https://doi.org/10.10.1088/1367-2630/15/12/125016

57. Muckl, A., Schwarz-Schilling, M., Fischer, K., \& Simmel, F. C. Filamentation and restoration of normal growth in Escherichia coli using a combined CRISPRi 
sgRNA/antisense RNA approach. PLoS One.13, e0198058 (2018) https://doi.org/10.1371/journal.pone.0198058

58. Vijay, S., Mukkayyan, N. \& Ajitkumar, P. Highly deviated asymmetric division in very low proportion of mycobacterial mid-log phase cells. Open Microbiol J $\mathbf{3 0}$, 40-50 (2014b). https://doi.org/10.2174/1874285801408010040

59. Smeulders, M. J., Keer, J., Speight, R. A. \& Williams, H. D. Adaptation of Mycobacterium smegmatis to stationary phase. J Bacteriol 181, 270-283. (1999). https://doi.org/10.1016/j.tube.2006.10.004

60. Thanky, N. R., D. B. Young, and B. D. Robertson. Unusual features of the cell cycle in mycobacteria: polar-restricted growth and the snapping model of cell division. Tuberculosis (Edinburgh) 87, 231-236. (2007) https://doi.org/10.1016/j.tube.2006.10.004

61. Markova, N., Slavchev, G., \& Michailova, L. Unique biological properties of Mycobacterium tuberculosis L-form variants: impact for survival under stress. Int Microbiol. 15, 61-68 (2012) https://doi.org/10.10.2436/20.1501.01.159

62.Wu, M. L., Gengenbacher, \& M., Dick, T. Mild Nutrient Starvation Triggers the Development of a Small-Cell Survival Morphotype in Mycobacteria. Front Microbiol. 7, 947 (2016) https://doi.org/10.10.3389/fmicb.2016.00947

63. Dow A., Prisic S. 2018. Alternative ribosomal proteins are required for growth and morphogenesisof Mycobacterium smegmatis under zinc limiting $\begin{array}{llll}\text { conditions. } & \text { PLoS } & \text { One. } & \text { 13, }\end{array}$ https://doi.org/10.1371/journal.pone.0196300

64. Dwyer, D. J., Kohanski, M. A. \& Collins, J. J. Role of reactive oxygen species in antibiotic action and resistance. Curr Opin Microbiol 12, $482-489$ (2009). https://doi.org/doi:10.1016/j.mib.2009.06.018 
65. Kohanski, M. A, DePristo, M. A. \& Collins, J. J. Sublethal antibiotic treatment leads to multidrug resistance via radical-induced mutagenesis. Mol Cell 37, 311-320 (2010). https://doi.org/doi:10.1016/j.molcel.2010.01.003

66. Li, G. Q. et al. Sublethal vancomycin-induced ROS mediating antibiotic resistance in Staphylococcus aureus. Biosci Rep 35, e00279 (2015). https://doi.org/doi:10.1042/BSR20140167

67. Hoeksema, M., Brul, S. \& Ter Kuile, B. H. Influence of reactive oxygen species on de novo acquisition of resistance to bactericidal antibiotics. Antimicrob Agents Chemother 62, e02354-17 (2018). https://doi.org/10.1128/AAC0235417

68. Jin, M., Lu, J., Chen, Z., Nguyen, S. H., Mao, L., Li, J., Yuan, Z. \& Guo, J. Antidepressant fluoxetine induces multiple antibiotics resistance in Escherichia coli via ROS-mediated mutagenesis. Environ Int 120, 421-430 (2018). https://doi.org/10.1016/j.envint.2018.07.046

69. Grant, S. S., Kaufmann, B. B., Chand, N. S., Haseley, N. \& Hung, D. T. Eradication of bacterial persisters with antibiotic-generated hydroxyl radicals. Proc Natl Acad Sci USA 109, 12147-12152 (2012). https://doi.org/10.1073/pnas.1203735109

70.Piccaro, G., Pietraforte, D., Giannoni, F., Mustazzolu, A., \& Fattorini, L. Rifampin induces hydroxyl radical formation in Mycobacterium tuberculosis. Antimicrob Agents Chemother 58, 7527-7533 (2014). https://doi.org/10.10.1128/AAC.03169-14

71. Nandakumar, M., Nathan, C., \& Rhee, K. Y. Isocitrate lyase mediates broad antibiotic tolerance in Mycobacterium tuberculosis. Nat Commun 5, 4306 (2014). https://doi.org/10.1038/ncomms5306 
72. Klein, K., \& Yang, Z. Comparison of ambient air survival of Mycobacterium tuberculosis clinical strains associated with different epidemiological phenotypes. Int J Mycobacteriol 3, 211-213 (2014). https://doi.org/10.1016/j.ijmyco.2014.04.002

73.Zerulla, K., Ludt, K., \& Soppa, J. The plody level of Synechocystis sp. PCC 6803 is highly variable and is influenced by chemical and physical external parameters. Microbiology 162, $\quad 730-739$ (2016). https://doi.org/10.1099/mic.0.000264

74.Zerulla K, \& Soppa J. Polyploidy in haloarchaea: advantages for growth and survival. $\quad$ Front $\quad$ Microbiol $\quad 5, \quad 274$ https://doi.org/10.10.3389/fmicb.2014.00274

75. Zobell, C. E., \& Cobet, A. B. Filament formation by Escherichia coli at increased hydrostatic pressures. J Bacteriol 87, 710-719 (1964).

76. Pine, L., \& Boone, C. J. Comparative cell wall analyses of morphological forms within the genus Actinomyces. J Bacteriol 94, 875-883 (1967).

77. Radman, M. SOS repair hypothesis: Phenomenology of an inducible DNA repair which is accompanied by mutagenesis. Basic Life Sci 5, 355-367 (1975). https://doi.org/10.10.1007/978-1-4684-2895-7_48

78. Witkin, E. M. Ultraviolet mutagenesis and inducible DNA repair in Escherichia coli. Bacteriol. Rev. 40, 869-907.(1976)

79.Bos, J., Yakhnina, A. A., \& Gitai, Z. BapE DNA endonuclease induces an apoptotic-like response to DNA damage in Caulobacter. Proc Natl Acad Sci USA 109, 18096-18101 (2012). https://doi.org/10.1073/pnas.1213332109

80. Justice, S. S., Hunstad, D. A., Seed, P. C., \& Hultgren, S. J. Filamentation by Escherichia coli subverts innate defenses during urinary tract infection. Proc 
Natl Acad Sci USA 103, 19884-19889 (2006). https://doi.org/10.1073/pnas.0606329104

81. Stackhouse, R. R., Faith, N. G., Kaspar, C. W., Czuprynski, C. J., \& Wong, A. C. L. Survival and virulence of Salmonella enterica serovar Enteritidis filaments induced by reduced water activity. Appl Environ Microbiol 78, 2213-2220 (2012). https://doi.org/10.1128/AEM.06774-11

82.Zhang, Q. et al. Acceleration of emergence of bacterial antibiotic resistance in connected microenvironments. Science 333, 1764-1767 (2011). https://doi.org/10.1126/science.1208747

83. Ryan, F., J. Bacterial mutation in a stationary phase and the question of cell turnover. J Gen Microbiol 21, 530-549 (1959) https://doi.org/10.1099/00221287-213-530

84.Bos, J. et al. Emergence of antibiotic resistance from multinucleated bacterial filaments. Proc Natl Acad Sci USA 112, 178-183 (2015). https://doi.org/10.1073/pnas.1420702111

85. Von der Hude, W., Seelbach, A., \& Basler, A., Epoxides. Comparison of the Induction of SOS Repair in Escherichia coli and Bacterial Mutagenicity in the Ames test. Mutat Res 231, 205-218 (1990). https://doi.org/10.1016/0027$5107(90) 90027-2$

86. Kato, T., Watanabe, M., \& Ohta, T. Induction of the SOS response and mutations by reactive oxygen generating compounds in various Escherichia coli mutants defective in the mutM, mutY or soxRS loci. Mutagenesis 9, 245-251 (1994). https://doi.org/10.1093/mutage/9.3.245 
87. McKenzie, G. J., Harris R. S., Lee, P. L. \& Rosenberg, S. M. The SOS response regulates adaptive mutation. Proc Natl Acad Sci USA 97, 6646-6651 (2000). https://doi.org/10.1073/pnas.120161797

88. McKenzie, G. J., Lee, P. L., Lombardo, M. J., Hastings, P. J. \& Rosenberg, S. M. SOS mutator DNA polymerase IV functions in adaptive mutation and not $\begin{array}{llllll}\text { adaptive amplification. } & \text { Mol }\end{array}$ https://doi.org/10.1016/S1097-2765(01)00204-0

89. Miller, C. et al. SOS response induction by beta-lactams and bacterial defense against antibiotic lethality. Science 305, 1629-1631 (2004). https://doi.org/10.1126/science.1101630

90. Asad, N. et al. Several pathways of hydrogen peroxide action that damage the Escherichia coli genome. Genet Mol Biol 27, 291-303 (2004). http://dx.doi.org/10.1590/S1415-47572004000200026

91. Janion, C. Inducible SOS response system of DNA repair and mutagenesis in Escherichia coli. Int J Biol Sci 4, 338-344 (2008). http://dx.doi.org/10.7150/ijbs.4.338

92. Peng, Q. et al. Baicalein suppresses the SOS response system of Staphylococcus aureus induced by ciprofloxacin. Cell Physiol Biochem 28, 1045-1050 (2011). https://doi.org/10.1159/000335791

93. Rodriguez-Beltran, J., Rodriguez-Rojas, A., Guelfo, J. R., Couce, A., \& Blazquez, J. The Escherichia coli SOS gene dinF protects against oxidative stress and bile salts. PLoS One 7, e34791 (2012) https://doi.org/10.1371/journal.pone.0034791

94. Kreuzer, K. N. DNA damage responses in prokaryotes: Regulating gene expression, modulating growth patterns, and manipulating replication forks. 
Cold Spring Harb Perspect Biol (2013) https://doi.org/10.1101/cshperspect.a012674

95. Baharoglu, Z., \& Mazel, D. SOS, the formidable strategy of bacteria against aggressions. FEMS Microbiol Rev 38, 1126-1145 (2014). https://doi.org/10.1111/1574-6976.12077

96. Qin, T. T. et al. SOS response and its regulation on the fluoroquinolone resistance. Ann Transl Med 3, 358 (2015). https://doi.org/10.3978/j.issn.23055839.2015.12.09

97. Händel N, Hoeksema M, Freijo Mata M, Brul S \& ter Kuile B. H. Effects of Stress, Reactive Oxygen Species, and the SOS Response on De Novo Acquisition of Antibiotic Resistance in Escherichia coli. Antimicrob Agents Chemother. 60, 1319-1327. (2015) https://doi.org/10.1128/AAC.02684-15.

98. Dapa, T., Fleurier, S., Bredeche, M. F., Matic, I. The SOS and RpoS reg-ulons contribute to bacterial cell robustness to genotoxic stress by synergistically regulating DNA polymerase pol II. Genetics 206, 1349-1360 (2017) https://doi.org/10.1534/genetics.116.199471

99. Rodriguez- Rosado et al. The antioxidant drug N-acetylcysteine abolishes SOS-mediated mutagenesis produced by fluoroquinolones in bacteria. bioRxiv 428961; (2018) https://doi.org/10.1101/428961

100. Chistyakov, V. A., Prazdnova, E. V., Mazanko, M. S., Churilov, M. N., \& Chmyhalo, V. K. Increase in Bacterial Resistance to Antibiotics after Cancer Therapy with Platinum-Based Drugs. Mol Biol (Mosk) 52, 270-276 (2018) https://doi.org/10.7868/S002689841S020106

101. Crane, J. K., Cheema, M. B., Olyer, M. A., \& Sutton, M. D. Zinc Blockade of SOS Response Inhibits Horizontal Transfer of Antibiotic Resistance Genes 
in Enteric Bacteria. Front Cell Infect Microbiol 8, 410 (2018) https://doi.org/10.3389/fcimb.2018.00410

102. Hoeksema, M., Brul, S., \& Ter Kuile, B. H, Influence of Reactive Oxygen Species on De Novo Acquisition of Resistance to Bactericidal Antibiotics. $\begin{array}{lllll}\text { Antimicrob Agents } & \text { Chemother 62, e02354-17 }\end{array}$ https://doi.org/10.1128/AAC.02354-17

103. Geisinger, E. et al. The Landscape of Phenotypic and Transcriptional Responses to Ciprofloxacin in Acinetobacter baumannii: Acquired Resistance Alleles Modulate Drug-Induced SOS Response \& Prophage Replication. MBio 10, e01127-19 (2019). https://doi.org/10.1128/mBio.01127-19

104. Hussain, K., Begg, K. J., Salmond, G. P. \& Donachie, W. D. ParD: a new gene coding for a protein required for chromosome partitioning and septum localization in Escherichia coli. Mol Microbiol. 1, 73-81 (1987) https://doi.org/10.10.1111/j.1365-2958.1987.tb00529.x

105. Ireton, K., Gunther IV, N. W. \& Grossman, A. D. spo0J is required for normal chromosome segregation as well as the initiation of sporulation in Bacillus $\begin{array}{llll}\text { subtilis. } & \mathrm{J} & \text { Bacteriol. } & \text { 176, }\end{array}$ https://doi.org/10.10.1128/jb.176.17.5320-5329.1994

106. Maloney, E., Madiraju, M., \& Rajagopalan, M. Overproduction and localisation of Mycobacterium tuberculosis ParA and ParB proteins. $\begin{array}{lllll}\text { Tuberculosis } & \text { (Edinb) } & 89 & \text { (Suppl), } & \text { S65-S69 }\end{array}$ https://doi.org/10.1016/S1472-9792(09)70015-0

107. Sakai A, Nakanishi M, Yoshiyama K, \& Maki H. Impact of reactive oxygen species on spontaneous mutagenesis in Escherichia coli. Genes Cells 11, 767778 (2006). https://doi.org/10.1111/j.1365-2443.2006.00982.x 
108. Wakamoto, Y. et al. Dynamic persistence of antibiotic-stressed $\begin{array}{llll}\text { mycobacteria. } & \text { Science } & 339, & 91-95\end{array}$ https://doi.org/10.1126/science.1229858

109. Snapper, S. B., Melton, R. E., Mustafa, S., Kieser, T. \& Jacobs, Jr. W. R. Isolation and characterisation of efficient plasmid transformation mutants of Mycobacterium smegmatis. Mol Microbiol 4, 1911-1919 (1990). https://doi.org/10.1111/j.1365-2958.1990.tb02040.x

110. Bolshakova, A. V. et al. Comparative studies of bacteria with an atomic force microscopy operating in different modes. Ultramicroscopy 86, 121-128 (2001). https://doi.org/10.1016/S0304-3991(00)00075-9

111. Takade, A., Takeya, K., Taniguchi, H. \& Mizuguchi, Y. Electron microscopic observations of cell division in Mycobacterium vaccae V1. J Gen Microbiol 129, 2315-2320 (1983). https://doi.org/10.1099/00221287-129-7-2315

112. Vijay, S., Anand, D. \& Ajitkumar, P. Unveiling unusual features of formation of septal partition and constriction in mycobacteria-an ultrastructural study. $\mathrm{J}$ Bacteriol 194, 702-707 (2012). https://doi.org/10.1128/JB.06184-11

113. White, D. A., Mizada D. S. \& Nakamura R. M. Characterisation of the periodate oxidation of glycerol and related compounds, and application toward determination of serum triglyceride concentrations. Clin Chem 20, 645-648 (1974).

114. Nash, T. Calorimetric estimate of formaldehyde by means of the Hautzsch reaction. Biochem J 55, 416-421 (1953). https://doi.org/10.1042/bj0550416

115. Bondioli, P. \& Della Bella, L. An Alternative Spectrophotometric Method for the Determination of Free Glycerol in Biodiesel. Eur J Lipid Sci Technol 107, 153-157 (2005). https://doi.org/10.1002/ejlt.200401054 
116. de Jong, I. G., Beilharz, K., Kuipers O. P. \& Veening J. W. Live Cell Imaging of Bacillus subtilis and Streptococcus pneumoniae using Automated Timelapse Microscopy. J Vis Exp 53, 3145 (2011). https://doi.org/10.3791/3145

117. Joyce, G., Robertson, B. D. \& Williams, K. J. A modified agar pad method for mycobacterial live-cell imaging. BMC Res Notes 4, 73 (2011). https://doi.org/10.1186/1756-0500-4-733

118. Vijay, S., Nagaraja, M., Sebastian, J. \& Ajitkumar, P. Asymmetric cell division in Mycobacterium tuberculosis and its unique features. Arch Microbiol 196, 157-168 (2014a). https://doi.org/10.1007/s00203-014-0953-7

119. Setsukinai, K., Urano, Y., Kakinuma, K., Majima, H. J. \& Nagano, T. Development of novel fluorescence probes that can reliably detect reactive oxygen species and distinguish specific species. J Biol Chem 278, 3170-3175 (2003). https://doi.org/10.1074/jbc.M209264200

120. Mukherjee, P. et al. Novel role of Wag31 in protection of mycobacteria under oxidative stress. Mol Microbiol 73, 103-119 (2009). https://doi.org/10.1111/j.1365-2958.2009.06750.x

\section{Acknowledgements}

With highest respects and regards, PA dedicates this work as a tribute to Prof. T. Ramakrishnan (late), who led the pioneering, fundamental and foundation laying work on the biochemistry and molecular biology of Mycobacterium tuberculosis at Indian Institute of Science, Bangalore, India. 


\section{Funding}

The work was supported by funds from the DBT-IISc Partnership Programme (common shared grant) and Indian Institute of Science and the infrastructure facilities provided by DST-FIST, UGC-CAS, and IISc, in the MCB Dep't. Authors thank DBTsupported FACS facility at Biological Sciences Division. KJ and DS received SRFs from UGC, while RRN and AP received SRFs from CSIR. AvP received SRF from Indian Institute of Science.

\section{CONFLICT OF INTEREST STATEMENT}

The authors declare that they do not have any conflict of interest amongst themselves or with the funding agencies. The research was conducted in the absence of any commercial or financial relationships that could be construed as a potential conflict of interest.

\section{Author's contribution}

PA, KJ designed the experiments; PA contributed reagents, materials, and analysis tools; KJ, DS, RRN, AvP, AP performed experiments; PA, KJ, DS, RRN, AvP, AP analysed data; PA, KJ wrote the manuscript; all authors have read the manuscript. 
Table S1: Oligonucleotides used in the study

\begin{tabular}{|c|c|c|}
\hline Name & Oligonucleotide sequence & Purpose \\
\hline Msm-rpoB-RRDR-f & 5' gtcgtctgcgcaccgtc 3' & Sequencing \\
\hline Msm-rpoB-RRDR-r & 5' ctcgatgaagccgaacgg 3' & Sequencing \\
\hline
\end{tabular}

